\title{
PARÂMETROS HÍDRICOS E DE CRESCIMENTO DE DUAS VARIEDADES DE FEIJOEIRO (Dhaseolus oulgaris L.) SOB DIFERENTES CONDICCÕES DE DISPONIBILIDADE DE ÁGUA NO SOLO
}

HAMILTON JUSTINO VIEIRA

Orientador: Prof. Dr. LUIZ ROBERTO ANGELOCCI

Dissertação apresentada à Escola Superior de Agricultura "Luiz de Queiroz", da Universidade de São Paulo, para obtenção do título de Mestre em Agronomia - Área de Concentração - Agrometeorologia.

PIRACICABA

Estado de São Paulo - Brasil Junho - 1984 
A meus pais

OFEREÇO

Aos exemplos de, honestidade

e de força de vontade, como o de meus pais,

DEDICO 
"In twenty-eight years of farming I have never seen a normal year. It has always been too hot on cold or too wet on dry" - Robert Bergland Secretary of Agriculture, 1976. 


\section{AGRADEC IMENTOS}

Agradeço a todas as pessoas que de uma forma ou de outra concorreram para a realização deste trabalho, sem as quais não seria possĩvel à condução e término do mesmo.

Aos orgaos e instituições: EMPASC/S.A., CAPES, IAC, CENA, COOPERSUCAR e ESALQ pela cooperação e apoio dispensados para a realização deste trabalho. 
SUMARIO

pāgina

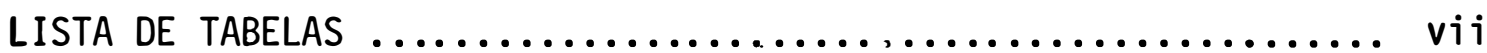

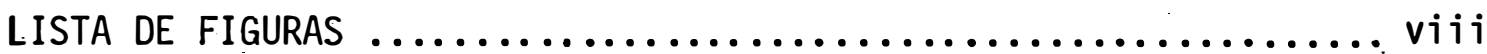

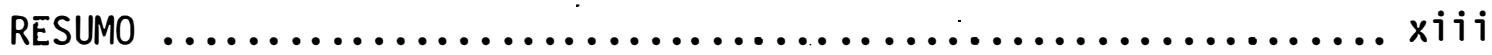

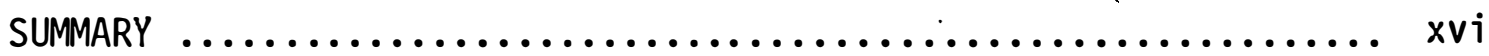

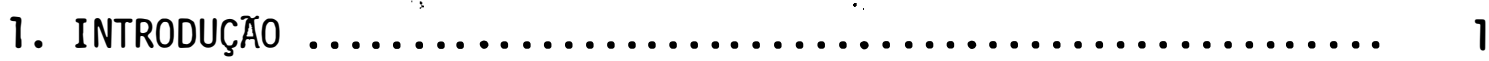

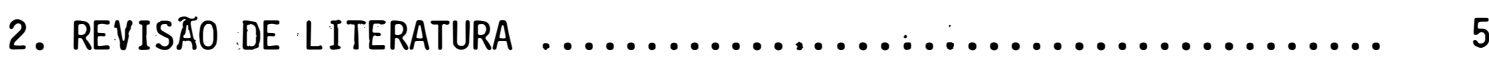

2.1. Resistēncia ao Transporte Hídrico no SSPA ............ 5

2.2. Distribuição do Sistema Radicular do Feijoeiro e

Extração de Água pelas Raízes .................... 14

2.3. Respostas do Feijoeiro às Condições Hîdricas no

Solo e na Planta .......................... 16

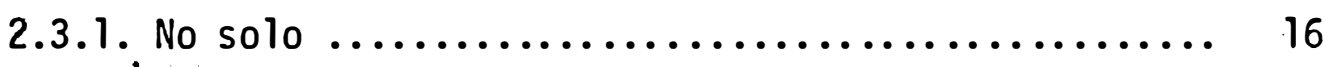

2.3.2. Na planta ................................ 22

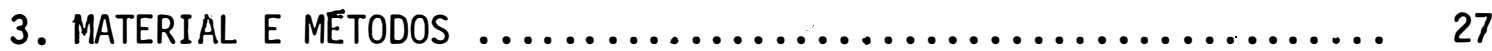

3.1. Local ................................... 27

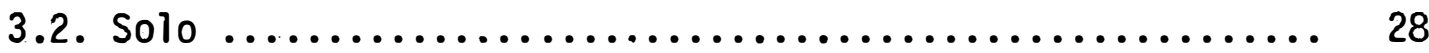

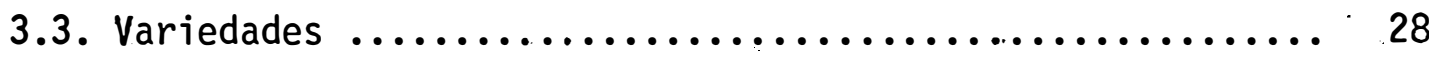

3.4. Tratamentos Utilizados ......................... 29

3.5. Determinação dos Parāmetros Relacionados ao Flụxo

Hídrico ....................................... 31

3.5.1. Balanço hïdrico no campo .................. 32

3.5.2. Evapotranspiração segundo o mëtodo de PENMAN ..... 36

3.5.3.. Cālculo da fração de āgua disponível (FAD) ...... 38

3.5.4. Potencial da água na planta ................ 39

3.5.5. Resistēncia estomātica à difusão de vapor e taxa de transpiração ..................... 41

3.5.6. Condições de demanda evaporativa da atmosfera 42 
pāgina

3.6. Determinações Fenolōgicas .................... 42

3.6.1. Dèterminação dos estādios fenolōgicos $\ldots \ldots \ldots \ldots .42$

3.6.2. Peso seco de plantas ................... 43

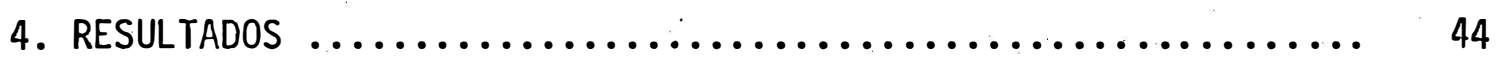

4.1. Relativos ao ciclo de desenvolvimento das culturas .... 44

4.1.1. Variação da āgua disponīvel do solo ........... 44

4.1.2. Duração dos estādios fenolōgicos e acúmulo de matēria seca ....................... 47

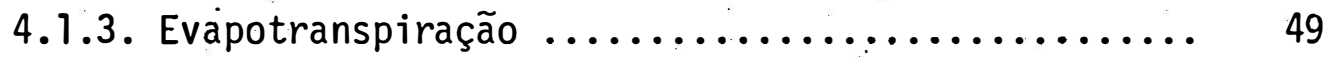

4.2. Relativos ao Perĩodo de Diferenciação dos Trata-

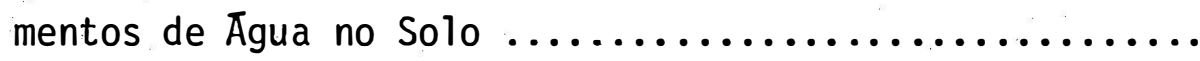

4.2.1. Valores médios diārios dos parâmetros medidos na planta e na atmosfera ............... 62

4.2.2. Variação durante o dia dos parâmetros medidos .... . 72

4.2.3. Variação dos parâmetros relacionados ao fluxo hîdrico e às condições meteorológicas no fotoperíodo e início do período noturno ....... 78 4.2.3.1. Na variedade Aroana $80 \ldots \ldots \ldots \ldots . .678$

4.2.3.2. Na variedade Aetē $3 \ldots \ldots \ldots \ldots \ldots \ldots . . . .64$

4.2.3.3. Comparação das duas variedades ....... 89

4.2.4. Valores dos parāmetros de āgua no solo ........ 94

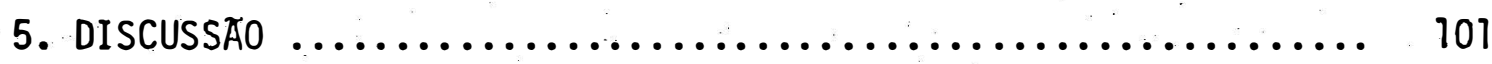

5.1. Dos Resultados Relativos a todo o Ciclo de Desenvolvimento das Culturas ....................... 101

5.2. Dos Resultados Relativos ao Período de Diferenciação dos Tratamentos de Agua no Solo ................ 107

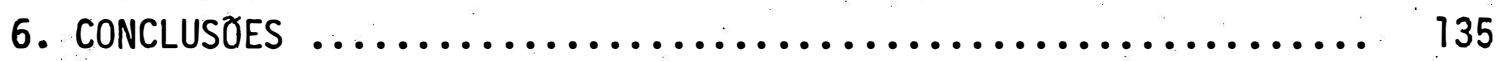

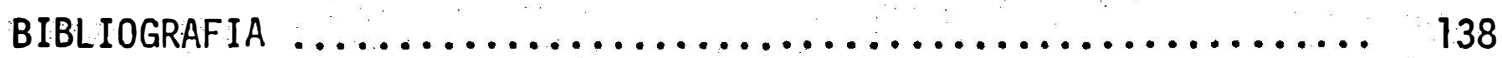




\section{LISTA DE TABELAS}

Tabela no

Pāgina

1 Evapotranspiração estimada pelo método do balanço hỉdrico no campo, para cada estádio fenológico do feijoeiro, nas três épocas de plantio, nos tratamentos sem interrupção (I) e com interrupção (D) da irrigação ................................ 55

2 Valores médios, durante o perīodo de interrupção da irrigação, do défice de saturação de vapor de água e temperatura do ar, da radiação solar global e da resistência estomática a difusão de vapor, para as variedades Aroana 80 e Aetē 3, em duas épocas de plantio; do potencial total da àgua na folha para a vari idade Aroana 80 em duas

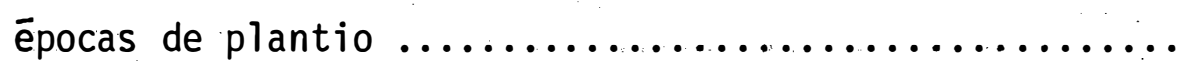

3 Valores médios dos potenciais osmótico e matricial $\left(\psi_{(0+m)}\right)$, de pressão $\left(\psi_{\mathrm{p}}\right)$ e matricial $\left(\psi_{\mathrm{m}}\right)$ da āgua na folha (das 06:30 às 17:30 horas) e do potencial osmōtico $\left(\psi_{0}\right)$ (das 06:30 às 18:30 horas) para as duas variedades e duas ēpocas de plantio, durante parte do perĩodo de interrupção da irriga-

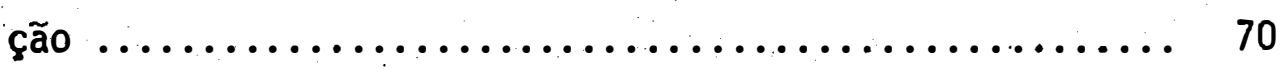




\section{LISTA DE FIGURAS}

Figura $n$ ?

Pāgina

1 Esquema da distribuição dos tratamentos na ārea experimental.

2 Variação da fração de àgua disponīvel (FAD) para as variedades Aroana 80 e Aeté 3 nas trēs épocas de plantio durante o ciclo de desenvolvimento da

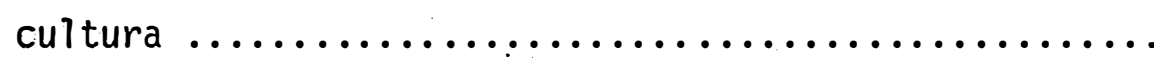

3. Caracterização dos estādios fenológicos da varie dade Aroana 80 e Aeté 3 nas trēs épocas de plantio de acordo com o tempo após a emergência ...

4 Variação da evapotranspiração acumulada das culturas determinada pelo método do balanço hídrico (ETC) e pelo método de Penman (ETp) para a varie. dade Aroana 80 e Aeté 3 na primeira época de

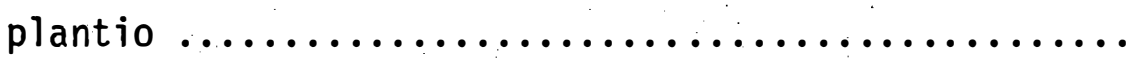

5 Variação da evapotranspiração acumulada das culturas determinada pelo método do balanço hídrico (ETc) e pelo método de Penman (ETp) para a varie dade Aroana 80 e Aeté 3 na segunda época de

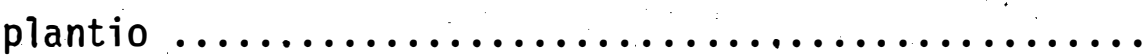

6 Variação da evapotranspiração acumulada das culturas determinada pelo método do balanço hídrico (ETc) e pelo método de Penman (ETp) para a varie dade Aroana 80 e Aetē 3 na terceira época de plantio 
Figura no

Página

7 Curvas representativas do acūmulo de matéria seca para a variedade Aroana 80 e Aetē 3 nas très

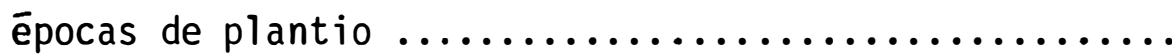

8 Variação dos valores médios diārios no fotoperīo do durante o período de secamento do solo, do défice de saturação do vapor de āgua e da temperatura do ar, da radiação solar global, do potencial total da soma do potencial osmótico e matricial e do potencial da água na folha, na variedade Aroana 80 nas duas épocas de. plantio

9 Variação da resistência estomātica média à difusão de vapor de água (entre 10:00 e 15:00 horas) durante o perĩodo de interrupção da irrigação pa rà as variedades Aroana 80 e Aetē 3 e duas épocas de plantio.

10 Variação da densidade do fluxo transpiratōrio (media horária entre 10:00 e 15:00 horas) durante 0 perĩodo de interrupção da irrigação para as variedades Aroana 80 e Aetē 3 e duas épocas de plan

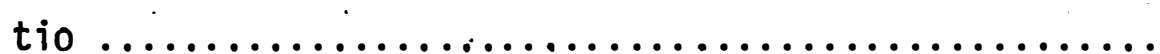

11 Variação dos valores médios horārios dos potenciais osmótico e matricial (entre 06:30 e 17:30 horas) e do potencial osmōtico (entre 07:30 e 18:00 horas) durante parte do periodo de interrupção da irrigação para as variedades Aroana 80

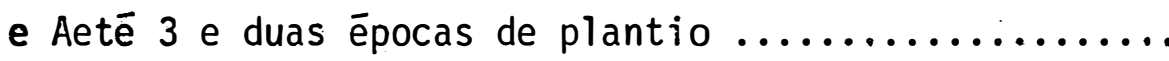


Figura no

Pāgina

12 Variação do potencial de água na folha, da densidade do fluxo transpiratório, da resistência estomática à difusão de vapor do defice de saturação de vapor e radiação solar global em vārios dias do período de interrupção da irrigação para a variedade Aroana 80

13 Variação do potencial de água na folha, da densidade do fluxo transpiratōrio, da resistēncia estomática à difusão de vapor do defice de saturação de vapor e radiação solar global em vārios dias do período de interrupção da irrigação para a variedade Aroana 80

14 Variação durante o período diurno e parte do noturno, do potencial total da āgua na folha $\left(\psi_{t}\right)$ de seus componentes, potencial osmótico $\left(\psi_{0}\right)$, po tencial de pressão $\left(\psi_{p}\right)$ e da soma dos potenciais osmótico e matricial $\left(\psi_{0+m}\right)$ na época e para os tratamentos de interrupção da irrigação..............

15 Variação durante o períndo diurno e parte do noturno, do potencial total da āgua na folha $\left(\psi_{t}\right)$ de seus componentes, potencial osmótico $\left(\psi_{0}\right)$, po tencial de pressão $\left(\psi_{p}\right)$ e da soma dos potenciais. osmōtico e matricial $\left(\psi_{0+m}\right)$ e para os tratamen tos de interrupção da irrigação................. 80

16 Variação dos valores de potencial osmótico da āgua na folha no fotoperiodo e primeiras horas noturnas na variedade Aroana 80 em duas epocas de plantio,durante e para os tratamentos de in-

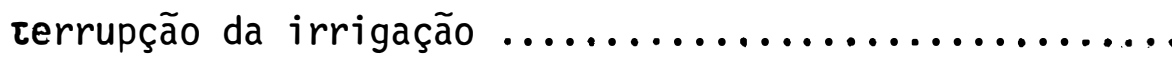


Figura nọ

Pāgina

17 Variação dos valores do potencial osmótico da água na folha no fotoperiodo e primeiras horas noturnas na variedade Aetē 3 em duas épocas de plantio, durante e para os tratamentos de inter-

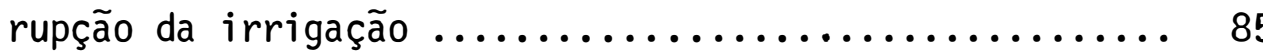

18 Variação da densidade de fluxo transpiratório e da resistência estomática à difusão de vapor de água na variedade Aetē 3 em duas épocas de plantio para os tratamentos com interrupção da irri-

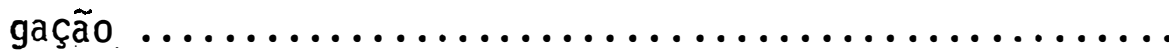

19 Variação do potencial da água na folha durante 0 fotoperíodo e parte do período noturno durante a época de interrupção da irrigação (cada ponto da curva representa a média da segunda e terceira épocas para as variedades Aroana 80. e Aeté 3).

20 Variação da soma do potencial osmōtico e matricial da água na folha durante o fotoperíodo e parte do perīodo noturno na época de interrupção da irrigação para a variedade Aroana 80 e

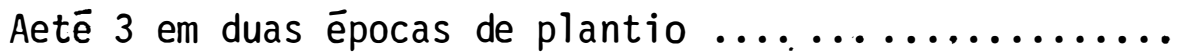

21 Variações horārias do potencial matricial da água no solo durante o período luminoso, nas diversas profundidades de instalação dos tensiōmetros,para a variedade Aroana $80 \mathrm{em}$ duas épocas de plantio durante o perĩodo de interrupção da irrigação 
Figura no

22 Variações horārias do potencial matricial da āgua no solo durante o período luminoso nas diversas profundidades de instalação dos tensiōmetros para a variedade Aeté 3 em duas épocas de plantio durante o perĩodo de interrupção da irrigação ....... 96

23 Variação da fração de água disponîvel no solo (FAD) para um perfil com profundidade de $475 \mathrm{~mm}$ durante o perĩodo de interrupção da irrigação

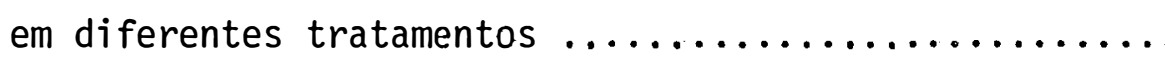


PARÂMETROS HIDRICOS E DE CRESCIMENTO DE DUAS VARIEDADES DE FEIJOEIRO

(Phaseolus vulgaris L.) SOB DIFERENTES CONDIÇOES DE DISPONIBILIDADE DE AGUA NO SOLO

Hamilton Justino Vieira Orientador: Dr. Luiz Roberto Angelocci

RESUMO

0 presente trabalho teve como objetivo estudar 0 consumo de água e as caracterîsticas morfofisiológicas do feijoeiro com a variação da água disponîvel no solo, sob condições de campo.

Para tanto utilizaram-se duas variedades de feijoei ro (Aroana 80 e Aetē 3 ) em três épocas de plantio com uma diferença de quinze dias entre elas. Para verificar as respostas das duas variedades às condições de défice hîdrico, a partir de um determinado tempo apōs a emergência (72. dias para a primeira, 58 dias para a segunda e 42 dias para a terceira época de plantio) suspendeu-se a irrigação em uma parcela de cada época de plantio para as duas variedades (tratamentos "D"); as demais parcelas foram conduzidas sem suspensão de irrigação (tratamentos "I"). A partir do segundo dia após a suspensão da irrigação acompanhou-se para os tratamentos "D", no perĩodo diurno, a variação do potencial da āgua no solo nas diversas profundidades, da resistência estomātica à difusão do vapor d'água e da densidade do fluxo 
transpiratōrio, para a segunda e ter̀ceira épocas de plantio nas duas variedades; para o Aroana 80 foram determinados o potencial total da ăgua na folha $\left(\psi_{t}\right)$ e seus componentes osmótico $\left(\psi_{0}\right)$, de pressão $\left(\psi_{p}\right)$ e da soma do osmótico e matricial $\left(\psi_{0+m}\right)$.

0 consumo de àgua foi estimado pelo método do balanço de āgua. Os resultados mostraram que a fração de āgua disponĩvel (FAD) no perfil de solo ate $675 \mathrm{~mm}$ de profundidade atingiu valores minimos durantẹ o perĩodo de suspensão da irrigação, em torno de 0,40 . Nos tratamentos sem interrupção da irrigação essa fração variou de 0,52 a 0,60 para as diferentes épocas de plantio. 0 grau de estresse hĩdrico foi atenuado pela redistribuição noturna da āgua no solo. Devido a isto, não ocorreram variações bruscas nos valores de resistência estomātica à difusão de vapor d'água e densidade de fluxo transpiratório. No entanto, a variação de $\psi_{t}$, com valores mĩnimo de $-1,4 \mathrm{MPa}$, e de $\psi_{\mathrm{p}}$, com valures mīnimos de $+0,2 \mathrm{MPa}$, provavelmente foi responsāvel pela diminuição da expansão das folhas e do aparecimento de novos órgãos, fato este caracterizado em maior grau na terceira e segunda épocas de plantio da variedade Aroana 80.

A variedade Aeté 3 mostrơ um comportamento diferente nas seguintes caracterīsticas, com relação ao Aroana 80: emissão de uma guia vegetativa; estádios reprodutivos menos definidos; movimento foliar de parahéliotropismo mais precoce, tanto com relação ao perĩodo de estresse como dentro do perĩodo diurno; resistēncias estomāticas médias à difusão de vapor d'āgua ligeiramente mais elevadas, densidade de fluxo transpiratório, consumo global de àguà e redução de 
acūmulo de matēria seca menores nos tratamentos que sofreram interrupção da irrigação, maior acúmulo de matéria seca em todos os tratamentos.

A evapotranspiração acumulada no ciclo de desenvolvimento para a variedade Aroana 80 variou de 286,9 a 320,8 e de 341,7 a $467,2 \mathrm{~mm}$ para os tratamentos com e sem interrupção de irrigação respectivamente. Para a variedade Aetē 3 variou de 291,3 a $307,1 \mathrm{~mm}$ nos tratamentos com interrupção da irrigação. 
HYDRIC AND GROWTH PARAMETERS FOR TWO BEAN (Phaseolus vulgaris L.) VARIETIES UNDER DIFFERENTE CONDITIONS OF SOIL WATER AVAILABILIY

Hamilton Justino Vieira Adviser: Dr. Luiz Roberto Angelocci

SUMMARY

The aim of the present work was to study the water comsumption and the morphophysiological characteristics of bean plants in relation to the variation of the available water, under field conditions.

To this purpose two varieties of bean plants (f.:-oana 80 and Aeté 3 ) were used, in 3 different planting times, with a time interval of 15 days between them. To check the responses of these two varieties to the conditions of water stress, some time after emergency (72, 58 and 42 days for the first, second and third planting times, respectively). irrigation was stopped for one plot of each planting time, for the two varieties (treatments "D"); irrigation was maintained for the two remaining plots (treatment "I"). As from the second day. after stopping irrigation, the plots in treatment "D" were observed, during the daylight period, for variation in the soil water potential at the various depths, stomatal resistance to water vapor diffusion and density of transpiratory flow, for the second and third planting times for the two varieties; for 
the Aroana 80, determinations were made of the leaf water total potential $\left(\psi_{t}\right)$ and its osmotic $\left(\psi_{0}\right)$ and pressure $\left(\psi_{p}\right)$ components, and of the summation of the osmotic and matrix $\left(\psi_{0+m}\right)$ potentials.

The water consumption was estimated by the water balance method. The results showed that the fraction of water available (FAD) in the soil profile to a depth of $675 \mathrm{~mm}$ reached minimum values during the non-irrigation period, around 0.40. In the treatments where irrigation was not stopped this fraction varied from 0.52 to 0.60 for the different planting times. The degree of water stress was attenuated by the night time redistribution of water in the soil. Owing to this, unexpected variations did not occur in the values of stomatal resistance to water vapor diffusion and density of transpiratory flow. However, the variation in $\psi_{t}$, with minimum values of $-1.4 \mathrm{MPa}$; and of $\psi_{p}$, with minimum values of $+0.2 \mathrm{MPa}$, can probably account for the decrease in the leaf expansion and for new shoots, a fact characterized to greater extent in the third and second planting times for the variety Aroana 80.

The variety Aetē 3 showed a different behaviour when compared to the Aroana 80, regarding the following characteristics: emission of twining; less clearly defined reprodutive stages; earlier paraheliotropic leaf movement, either in relation to the stress period as within the daylight period; slightly higher average for stomatal resistance to water vapor diffusion; lower density of transpiratory flow, lower global water comsumption and lower reduction of dry matter accumulation in the treatments which underwent interruption of irrigation; greater dry matter accumulation in all treatments. 
The accumulated evapotranspiration in the development cycle for the var. Aroana 80 varied from 286.9 to 320.8 and from 341.7 to $476.2 \mathrm{~mm}$ for the treatments with and without interruption of irrigation, respectively. For the variety Aetē 3 it varied from 291.3 to $307.1 \mathrm{~mm}$ in the treatments where irrigation was stopped. 


\section{INTRODU ÇAOO}

0 Brasil tem posição de destaque na produção mundial de feijão, contribuindo com mais de $20 \%$ da ārea total plantada no mundo, nos ūltimos anos. Além do Brasil, a India, o México e os Estados Unidos também são considerados grandes produtores mundiais, contribuindo com cerca de $70 \%$ da ārea e da produção totai:. Observando-se os dados de rendimento (quadro A), nota-se que com exceção do Brasil, todos os outros grandes produtores apresentaram ganho de rendimento na presente década em relação ao período de 1969-1971. No Brasil, ao conträrio, ocorreram nos trés primeiros anos desta década rendimentos, em média, $28 \%$ menores que no triēnio 1969-71, o que pode ser atribuĩdo ao fato de que a expansão de ārea cultivada deu-se, com algumas exceções, em regiões de solo e clima nem sempre adequados à cultura e variedades atē então disponíveis, além da quase inexistência de programas de pesquisa agronômica e de instrumentos de apoio voltados para esta atividade, resultando numa situação de baixa rentabilidade (PROGNOSTICO, 83/84, 1983). 
Alēm do fato de o Brasil não mostrar decrēscimo no rendimento de feijão, como os paîses citados, encontra-se colocada em penūitimo lugar com uma médiá para os períodos de 1969-71, 1981, 1982 e 1983 inferior à média mundial.

Quadro A - Rendimento do feijão, segundo principais paîses produtores e total mundial, 1969-82.

\begin{tabular}{lcccc}
\hline Paĩses & $1969-71$ & 1980 & 1981 & 1982 \\
\hline Brasil & 642 & 424 & 465 & 505 \\
Mexico & 506 & 551 & 683 & 524 \\
Estados Unidos & 1.403 & 1.625 & 1.620 & 1.555 \\
China & 796 & 842 & 996 & 946 \\
India & 283 & 308 & 310 & 294 \\
Mundo & 521 & 523 & 567 & 548 \\
\hline
\end{tabular}

FONTE: Food and Agriculture Organization (FAO), citado por PROGNOSTICO $83 / 84$.

Esta situação è provocada por vārios fatores, entre eles como jā citados anteriormente está o uso inadequado de variedades, doenças e condições climāticas. Neste ūttimo caso, pode-se verificar que as variações de disponibilidade hĩdrica contribuem de maneira significativa para a redução do rendimento. Uma maneira de impedir ou amenizar que perīodos de dēfice hỉdrico afetem o rendimento final da cultura somente é possiviel através do conhecimento das características edafo-climāticas da região de cultivo e das respostas de uma determinada espēcie em função dos parāmetros que atuam no seu desenvolvimento. Apōs o conhecimento de ambos (características edafo- 
climáticas e respostas das plantas) procura-se adequar a espécie à região considerada. Para regiões com perĩodos de défice hĩdrico TURNER e BEGG (1981) sugerem que as caracterīsticas desejāveis nas espēcies para uma boa adaptação a estas condições são: a) rāpida germinação e estabelecimento precoce de raĩzes profundas; b) rápido desenvolvimento fenológico; c) desenvolvimento plāstico com movimentos foliares de fotonastismo; d) alta sensibilidade do processo de expansão das folhas ao défice hídrico; e) alta sensibilidade dos estômatos a altos valores de défice de satuação de vapor d'água na atmosfera; f) habilidade para ajustamento osmótico; g) grande poder de transferência de assimilados do caule para as sementes; $h$ ) tolerância a deshidratação, particularmente durante o estádio de plāntula e do enchimento de grãos.

Desse modo estudos que levem a um maior conhecimento de como as espécies e variedades se comportam quanto a essas características, podem contribuir, atravēs de programas de melhoramento vegetal, do zoneamento agrỉcola e de irrigação, para aumentar o seu rendimento.

Com o objetivo geral de aumentar tal conhecimento em feijoeiro, foi realizado o presente estudo utilizando-se as variedades Aroana 80 e Aetē 3 , as quaìs foram escolhidas com base em observações sobre uma possível resposta diferencial ao défice hîdricn no solo.

Para tanto foram fixados os seguintes objetivos: 
Estudar a variação da extração e do consumo de água do solo sob diferentes condições de desenvolvimento da cultura do feijoeiro nas duas variedades, sob mesmas condições de demanda atmosférica e diferentes nîveis de āgua disponível no solo.

- Verificar a variação do potencial total da āgua na planta em relação às condições de demanda atmosférica que se apresentaram, em função do estado energético da āgua do solo, para a variedade Aroana 80.

- Verificar as possíveis relações entre o potencial da água na planta e no solo, com a resistência estomática à difusão de vapor d'água bem como a influência dos mesmos no consumo de āgua e no acūmulo de matéria seca para a variedade Aroana 80 e Aeté 3.

- Estudar as possiveis diferenças entre as variedades quanto as respostas ao estresse hîdrico, em relação aos parâmetros estudados no sistema solo-planta-atmosfera.

- Constatar fatores que concorreram para agravar ou atenuar o estresse hídrico, tanto àqueles pertinentes a planta, quanto aos do solo e àos da atmosfera. 


\section{REV ISAO DE LITERATURA}

2.1. Resistēncia ao Transporte Hî́drico no Sistema Solo Planta

$$
\text { Atmosfera (SSPA) }
$$

Para que âs plantas realizem a bioconversão da energia solar atravēs do processo da fotossīntese è necessārio que o fluxo hídrico mantenha-se adequado, de maneira que as folhas sirvam de anteparo à radiação solar, e se comportem como el ementos de trocas gasosas atravēs da abertura de seus estômatos.

A perda desta turgidez, por um motivo qualquer, acarreta uma diminuição na eficiēncia da bioconversão em função da influência direta ou indireta nos processos metabólicos envolvidos no desenvolvimento das plantas.

Segundo TURNER e BEGG (1981), o défice hỉdrico ocorre nos tecidos de todas as plantas que estão transpirando a uma taxa relativamente alta, como uma inevitāvel consequência das resistências ao fluxo da āgua ao longo do caminho solo-planta-atmosfera. Segundo os 
autores, durante os estágios iniciais de um período de secamento do solo, en quanto a água está inteiramente disponīvel na zona radicular no início do perĩodo luminoso, os estōmatos se encontram abertos e a água evapora-se das células do mesōfilo das folhas através da cutĩcula e principalmente atravēs dos estōmatos. Essa evaporação ou transpiração desen volve o défice hĩdrico na folha, no caule e nas raîzes. Neste perīodo a absorção de água pelo sistema radicular é maior que a transpiração; no transcorrer do dia ocorrerá um perĩodo de transição onde a taxa de absorção de āgua iguala-se a taxa de transpiração, momento no qual o potencial da água nos tecijdos condutores e tecidos adjacentes aproximám -se do equilíbrio. Passando este período de transição, a taxa de transpiração excede a de absorção de água pelas raízes e a planta se encontrarā em défice hî́drico. Durante a tarde, a planta novamente passarā por um perĩodo de transição, após o qual ainda se encontrarā em défice hĩdrico, mas nessa fase a absorção de āgua pelas raīzes serā maior do que aquela perdida por transpiração. Somente no fim do perĩodo luminoso, ou a noite, dependendo das condições de umidade do solo, è que a planta recuperar-se-à deste défice hĩdrico.

A restrição do solo à absorção de água pelas raízes. é função da tensão da águà, e o. fluxo hĩdrico para a epiderme das raīzes è função da diferença entre o potencial da àgua no solo e da prōpria epiderme, sendo que a magnitude desta diferença para uma determinada umidade constitui a força causadora do movimento ou fluxo da āgua (HILLEL, 1970).

Apōs uma chuva ou irrigação em um perĩodo inicial, quando o potencial da āgua no solo estā, de modo genérico, aproximadamente 
entre 0 e -0,25 MPa, GARDNER e NIEMAN (1964) afirmam que a āgua está inteiramente disponível a vegetal. Neste período o potencial da água na planta mostra pouca dependência do potencial da āgua no solo, mas quando a condutividade do solo torna-se menor, pode haver restrição ao movimento da āgua para as raîzes.

RITCHIE (1974; 1981) afirma que a intensidade desse estresse hĩdrico ē função das condições atmosfēricas e de āgua no solo, bem como das características anatömicas e morfológicas do vegetal, ou seja, dependendo das condições reinantes, cada segmento irā opor um determinado grau de resistência ao fluxo hĩdrico.

A literatura é controversa quanto à importāncia relativa das resistências na fase líquida e na fase gasosa do caminho de transporte hîdrico desde o solo atē a atmosfera. REICHARDT (1975) afirma que a menor resistência está no camịnho entre a folha e a atmosfera; LEVITT (1966) e SANCHEZ-DIAZ e MOONEY (1979) afirmam que a resistência na fase líquida é muito maior do que na fase gasosa.

Os valores relativos das resistências ao fluxo hîdrico no sistema solo-planta apresentados na literatura devem ser tomados com cautela, pois não existe consenso entre os pesquisadores quanto ao segmento que opõe maior resistência. Enquanto um grupo adota a hipōtese de que a resistência predominante localiza-se no solo (GARDNER, 1960; MACKLON e WEATHERLEY, 1965), outro sugere que ela localiza-se na planta (ANDREWS e NEWMAN, 1968; BOYER, 1969; HANSEN, 1974a, 1974b ; TAYLOR e KLEPPER, 1975; BLIZZARD e BOYER, 1980; SAMUI e KAR, 1981), ha vendo um terceiro grupo que adota a hipótese da resistência da planta 
ser predominante até um certo valor de potencial da āgua no solo, a partir do qual a resistência do solo predominaria (REICOSK'Y e RITCHIE, 1976; SEATON et alii, 1977; BURCH, 1979; ZUR et alii, 1982).

Dentro da planta, hā sugestões de que a maior resistēncia ocorre na raiz em relação aos demais segmentos da planta (caule, ramos e folhas) e que dentro do sistema radicular, o caminho radial apresentaria a maior resistência em relação ao axial como determinaram BOYER (1971) para soja e girassol, BURCH (1979) para trevo branco e pastagem e ROWSE e GOODMAN (1981) para alfafa; entretanto, para feijoeiro, BOYER (1971) verificou que a resistência axial na raiz foi ligeiramente maior que a radial, sendo a resistência total da planta em feijoeiro sempre menor que a da soja e do girassol.

Dentre as resistências ao fluxo hỉdrico no SSPA, aquela relativa aos estômatos desempenha papel fundamentail, pois tais estruturas ocupando uma posição chave do caminho de transporte de āgua, representa uma resistência que se localiza na interface dos sistemas lí quido e gasoso e que pode tornar-se de extrema importância em determinadas condições de défice hĩdrico.

COWAN (1977) afirmou que o comportamento estomático pode condicionar o potencial e consumo de água pela planta enquanto em outras vezes ele é ditado pelo potencial de āgua na planta em interação com o potencial de āgua do solo, na ārea de abrangência da rizosfera, e pela demanda atmosférica.

Segundo RITCHIE (1974), para a maioria das plantas, em condições de alta umidade do solo, para um dia com alta demanda 
evaporativa e outro com baixa condição de demanda, os valores de resis tência estomātica são baixos e aproximadamente iguais para estes mesmos dias. Para condições de baixa umidade do solo em um dia com alta e outro com baixa demanda evaporativa, a resistência estomática é alta e praticamente a mesma, pois a umidade do solo atingiu um nível crítico, e mesmo em um dia com baixas condições de demanda evaporativa os estōmatos fecham parcialmente.

COWAN (1977) e FARQUHAR (1978) afirmaram que o aumento da resistência estomática pode ocorrer quando uma alța taxa de transpi ração provoca uma queda do potencial de pressão da āgua ria folha, mecanismo chamado de retroalimentação ("FEEDBACK") ou esse aumento da resistëncia è causado pela influência direta dos elementos do meio, os quais são responsāveis pela variação da densidade do fluxo transpiratōrio, mecanismo denominado de "FEEDFORWARD".

Estudando a influência dos parāmetros do meio no comportamento estomātico em feijoeiro, KANEMASU e TANNER (1969b) sujeitaram as plantas á períodos intercalados de luz e escuro e verificaram que a abertura e o fechamento estomātico ocorreram em vinte minutos e que as resistências estomāticas da face abaxiál e adaxial foram independentes com relação ao fator estudado. Quando a face abaxial foi colocada em condições de luminosidade ou de sombreamento os valores de resistência.estomātica foram aproximadamente iguais, sendo que quan do a superfície adaxial foi submetida as mesmas condições, os valores de resistência estomātica tiveram os maiores valores na condição de sombreamento. Alēm desta diferença de comportamento, verificaram que 
existiu uma diferença entre os valores de resistēncia entre a face ada xial e a abaxial da folha sendo esta diferença função de uma densidade diferencial dos estômatos, sendo esta na face abaxial, sete vezes maior que a da face adaxial.

Estudando o comportamento estomático em plantas de feijoeiro, MILLAR e GARDNER (1972) verificaram que quando as plantas eram bem supridas de āgua, a abertura estomática foi grandemente controlada pela intensidade luminosa, nîvel nutricional e concentração de $\mathrm{CO}_{2}$. Com a diminuição do potencial da água: no solo e consequentemente na planta, ocorreu uma queda da densidade do fluxo transpiratōrio em função da redução da abertura estomātica.

Com relação à temperatura e sua influẽncia na resis tência estomática a difusão de vapor d'āgua em feijoeiro, HOFSTRA e HESKETH (1969) mostraram que o acréscimo da abertura estomática, para uma variação de temperatura entre 15 e $36^{\circ} \mathrm{C}$, foi função quase $1 i$ near do acréşcimo de temperatura. Verificaram, tambēm, que os valores da abertura estomática da face superior foram próximas de zero à temperaturas inferiores a $21^{\circ} \mathrm{C}$ e para a face inferior da folha os valores da abertura estomática foram mĩnimos. Para temperaturas em torno de 30 a $36^{\circ} \mathrm{C}$ a diferença de abertura estomática entre as faces não foi significativa.

No entanto, WILSON (1975), estudando o efeito de temperaturas mais baixas em plantas de feijoeiro, mostrou que ao transferir plantas de um ambiente a $25^{\circ} \mathrm{C}$ e umidade relativa de $85 \%$ para um a $5^{\circ} \mathrm{C}$ e umidade relativa de $85 \%$, ocorreu a deshidratação das mesmas; o autor 
sugere que este fato foi devido a uma maior abertura estomática a $5^{\circ} \mathrm{C}$ do que a $25^{\circ} \mathrm{C}$, pois em uma fase de complementação do experimento notou que a abertura estomātica das plantas a $25^{\circ} \mathrm{C}$ teve um decréscimo gradual e doze horas depois essa abertura era somente a metade da inicial, enquanto que para as condições a $5^{\circ} \mathrm{C}$ elas atingiram o máximo em duas horas e os estômatos não mais se fecharam e para $12{ }^{\circ} \mathrm{C}$ o tempo con siderado foi de três horas.

HIRON e WRIGHT (1973), condicionando plāntulas de feijoeiro a jatos de ar quente $\left(38^{\circ} \mathrm{C}\right)$, verificaram que as folhas murcharam e, em consequência, a resistēncia estomātica atingiu valores elevados. Com o fechamento estomático estas folhas novamente recuperaram a turgescência. 0 tempo necessário para que todo este - processo acontecesse foi de aproximadamente 90 minutos. Paralelamente $\bar{a}$ medida da resistēncia estomātica à difusão de vapor com a determinação do ácido abcisico $(A B A)$, verificaram que o nível deste hormônio foi mĩnimo no inî́cio do ciclo, māximo por ocasião do fechamento estomático e mĩnimo ao final dos 90 minutos. A conclusão tirada pelos autores é que com o murchamento incipiente das folhas, ocorreu uma elevação do nível do $A B A$ que provocou o fechamento estomático; com isto a taxa de transpiração foi diminuĩda e a planta recuperou sua turgescência, quan do os níveis de ABA voltaram a diminuir, e com isto a taxa de transpiração aumentou novamente induzindo a planta a reiniciar o processo.

Deve-se considerar que a discordāncia entre os dois ūitimos trabalhos com relação ao de HOFSTRA e HESKETH (1969) pode ser função da maior taxa de incremento da temperatura aplicado por WILSON 
(1975) e por HIRON e WRIGHT (1973), pois a evolução do aumento de temperatura não foi controlada no primeiro trabalho.

Como pode-se notar, as respostas dos estômatos às condições do meio e da prōpria planta têm sido muito estudadas, devido à sua importāncia como regulador de perda de āgua e taxa de absorção de diōxido de carbono e principalmente devido às suas respostas ao dēfice hỉdrico, experimentado pelas plantas, porque os mesmos não respondem às variações de potenciais da āgua na folha atē que nîveis críticos des te parâmetro sejam alcançados, a partir dos quais eles respondem drasticamente, mesmo para pequenas variações do potencial de água na foTha (HSIAO et alii,, 1977; BEGG e TURNER, 1981).

Em plantas de feijoeiro, a influência do estresse hijdrico, provocado por duas soluções de diferentes concentrações, foi es tudado por JENSEN (1981). As plantas cresciam em solução nutritiva com potencial de -0,07 $\mathrm{MPa}$; a partir do florescimento, os tratamentos diferenciais foram de $-0,07 \mathrm{MPa} ;-0,25 \mathrm{MPa}$ e $-0,45 \mathrm{MPa}$. Com estes tratamentos, quando o potencial da água na folha estava entre $-0,7 \mathrm{MPa} e$ $-0,9 \mathrm{MPa}$ ocorreu o fechamento estomático, e quando as mesmas apresentaram-se murchas, o potencial de āgua na folhà era de -1,0 $\mathrm{MPa}$. Fazendo uma relação entre a condutância estomática da face inferior da folha e o potencial de pressão da água na folha, notou que a condutância estomática aumentou com o acrēscimo do potencial de pressão da àgua atē quando o mesmo atingiu o valor de $0,3 \mathrm{MPa}$ e a partir deste ponto, a condutância permaneceu constante, indicando que 0 potencial da āgua na folha não reflete fielmente o estado de hidratação das cêlu las guardas. 
KANEMASU e TANNER (1969b)estudando a relação entre a re sistência estomātica à difusão do vapor d'água, o potencial da água na planta e a fotossintese, mostraram que as resistências estomáticas da superfície âdaxial das folhas aumentaram progressivamente apōs o potencial da āgua das folhas atingir $-0,8 \mathrm{MPa}$ e $-0,9 \mathrm{MPa}$ e que estas mes mas resistēncias na face adaxial permaneceram relativamente constantes até que o potencial da água na folha atingiu valores menores que $-1,1$ ou $-1,2 \mathrm{MPa}$, a partir dos quais aumentaram rapidamente, impedindo uma maior redução do potencial da água na planta. As observações das resistências estomáticas à difusão do vapor d'água nas faces adaxial mostram que estas começam a aumentar 1 ou 2 dias antes do grande aumento da resistência estomätica da face abaxial e do estado de murchamento das folhas. Estas reduções na abertura estomática, segundo os autores, causam uma redução na transpiração, na absorção de $\mathrm{CO}_{2}$ e consequentemente na fotossintese.

Para 0'TOOLE et alii (1977), as taxas de fotossintese líquida e transpiração diminuiram quando o potencial da água nas folhas ' de feijoeiro alcançou $-0,3 \mathrm{MPa}$ a $-0,5 \mathrm{MPa}$, enquanto que nesta faixa de potencial da āgua na folha, a resistência estomática à difusão de vapor teve um aumento. Quando o potencial de água na folha esteve por volta de $-0,9$ a $-1,0 \mathrm{MPa}$, a fotossintese líquida e a taxa de transpiração aproximaram-se de zero. Este decréscimo paralelo na taxa de fotossintese líquida e taxa de transpiração, indicou neste experimento que o fechamento estomático foi a principal causa mediante estresse hỉdrico, da redução da fotossîntese líquida. Notou ainda o autor que a resistência do mesófilo aumentou e que a atividade da enzima RuDPase 
decresceu com a diminuição do potencial da āgua na folha, indicando a possibilidade de que ambos, controle estomático e resistência do mesō fịo, seriam responsầveis pela redução da fotossintese.

2.2. Distribuição do Sistema Radicular do Feijoeiro e Extração de Agua pelas Raĩzes.

Segundo SLAVIK (1974) o tamanho do sistema radicular determina o volume de solo que irā ser explorado pela rizosfera. A extensão horizontal desta rizosfera de uma planta em uma comunidade vegetal é primeiramente determinada pelas características específicas da espécie como também pela densidade populacional. E determinada também por outros dois fatores parcialmente opostos, ou seja, o nível do lençol freātico e a aeração do solo.

Para DOORENBOS e PRUITT (1975) a absorção da água pelas plantas é feita preferencialmente dentro do perfil de solo explorado pelas raizes. A maioria das culturas estudadas retiram $40 \%$ do to tal de āgua utilizada no quarto superior do perfil abrangido pelo sistema radicular e $30 \%, 20 \%$ e $10 \%$ do total de āgua utilizada da segunda, terceira e quarta fração do perfil do solo explorado pelas raîzes. Não existe porém um limite definido para esta absorção preferencial, porque podem ocorrer movimentos horizontais e verticais de āgua de perfis mais úmidos para aqueles que sofreram secamento. Para a cultura do feijoeiro aqueles autores afirmam que a maior efetividade do sistema radicular em absorver āgua ocorre em média até a profundidade de 50-90 cm quando a cultura está no seu estágio de pleno desenvolvimento. 
FISCUS (1979), em estudo das relações entre 0 sistema radicular e transporte de água em plantas de feijoeiro que variavam de 7 a 14 dias de idade, verificou que a condutividade das raîzes está mais relacionada com a ārea da sua superfície do que com a idade das plantas. No início do desenvolvimento das plantas a condutividade das raízes tiveram um acrēscimo atē atingirem um valor máximo e então decresceu, permanecendo constante atē o 410 dia. Este aumento na condu tividade das raízes segundo aquele autor pode ter sido devido ao desenvolvimento de raīzes primārias e secundārias, enquanto que a queda posterior da condutividade foi devido à suberização de parte da superfície das raîzes.

Relatam STANSEL e SMITLE (1980) que a extração de āgua pelas raĩzes do feijoeiro, em experimento conduzido em duas estações de crescimento (outono e primavera) e trēs anos distintos ocorreu prin cipalmente na camada de $0-30 \mathrm{~cm}$. Nas profundidades de $30-45 \mathrm{~cm}$ ¿̈ extração de ãgua foi pequena e nas profundidades abaixo de $45 \mathrm{~cm}$, independente dos tratamentos de estresse aplicado à cultura, a absorção não foi significativa.

INFORZATO e MYASAKA (1963), fażendo um estudo da distrị buição das raízes do feijoeiro em dois tipos de solo do estado de são Paulo, determinaram que os dez primeiros centimetros do perfil continham $74,5 \%$ das. raĩzes; nos primeiros $20 \mathrm{~cm}$ as raízes constituiam $83,6 \%$ do total. 0 restante das raîzes estavam distribuĩdos até $90 \mathrm{~cm}$. Para 0 solo tipo Arenito de Baurū, os primeiros $10 \mathrm{~cm}$ do perfil continham $37,4 \%$; nos primeiros $20 \mathrm{~cm}$ as raízes constitữam $97,4 \%$ do total, tambēm para este solo a profundidade máxima atingida pelas raízes foi $90 \mathrm{~cm}$. 
Em experimento de campo com feijoeiro REICHARDT et alii (1974) determinaram semanalmente a distribuição do sistema radicular, verificando no referido estudo que $90 \%$ das raĩzes estavam confinadas nos $30 \mathrm{~cm}$ superiores do perfil do solo.

BLACK et alii (1970aे), trabalhando com a cultura do feijoeiro em lisîmetros de pesagem e com tensiômetros, sujeitaram a cultura a dois períodos de secamento, verificando que durante o primeiro ciçlo de secamento do solo (34 a 43 dias apōs a emergência) a extração de água pela cultura foi restrita a $0-45 \mathrm{~cm}$. Durante o segundo ciclo (dos 47 e 54 dias apōs a emergência) a āgua foi retirada de $0-120 \mathrm{~cm}$ do perfil.

DASBERG e BAKKER (1970) confirmaram a influēncia oposta da aeração e umidade do solo no crescimento das raĩzes do feijoeiro, sendo que quanto maior foi a umidade e menor a aeração, menor foi o desenvolvimento radicular das piantas, sendo o inverso também verdadeiro.

Por sua vez a aeração do solo, para tensões de umidades não limitantes ao desenvolvimento das plantas, guarda uma relação exponencial com a produção de matéria seca pelo feijoeiro, segundo LEGARDA e FORSYTHE (1978).

2.3. Respostas do Feijoeiro às Condições Hĩdricas no Solo e na Plan$\underline{\text { ta }}$

2.3.1. No solo

A quantificação de parâmetros envolvidos nas relações 
hîdricas das culturas de interesse econômico è importante para caracterizar o comportamento destas frente a défices hídricos, fornecendo subsídios aos estudos de resistências a seca e de exigências em āgua pelas diferentes variedades, atendendo vārias āreas da ciência agronômica como a de melhoramento vegetal, a agrometeorologia e a prātica irrigacionista. Dentre as determinações que se realizam neste sentido, destacam-se as de evapotranspiração e a influência do dēfice hỉdrico.

Com relação ao consumo de āgua, SILVEIRA e STONE (1978), realizando o balanço hĩdrico no campo de uma cultura de feijão desenvolvendo-se em condições ótimas de umidade, determinaram que o consumo total de āgua pela cultura foi de $220,5 \mathrm{~mm}$. Para os diferentes estádios de desenvolvimento, o consumo foi de $3,2 \mathrm{~nm}$. dia ${ }^{-1}$ para o perīodo de germinação à floráção; $3,2 \mathrm{~mm} \cdot \mathrm{dia}^{-1}$ para o período de floração e de $1,7 \mathrm{~mm}$ para o perîodo de desenvolvimento de vagens atë a maturação corresponden :es a 0,62;0,77 e 0,38 do tota.l da evaporação do tanque "Classe A".

ENCARNAÇAO (1980), conduzindo a cultura de feijoeiro em evapotranspirômetros a nĩvel de lençol freātico constante, determinou que durante o perîodo vegetativo o consumo médio diārio de āgua foi de $3,8 \mathrm{~mm}$; no período de floração de $4,8 \mathrm{~mm}$ e no final do período de frutificação de $4,2 \mathrm{~mm}$ e na maturação fisiológica $3,8 \mathrm{~mm}$. 0 consumo total de àgua durante todo o ciclo foi de $284 \mathrm{~mm}$.

LUCHIARI (1978) encontrou um valor médio de $3,0 \mathrm{~mm} . \mathrm{dia}^{-1}$ : de evapotranspiração para todo o ciclo de uma cultura de feijoeiro desde o plantio até a maturação e o coeficiente médio de tarque para todo o ciclo da cultura foi de 0,88 . 
REICHARDT et alii (1974), atravēs do balanço hĩdrico no campo,determinaram a evapotranspiração do feijoeiro da variedade Carioca no período compreendido entre o início da fase vegetativa até 45 dias apōs; o total de āgua consumido pela cultura foi de $165,7 \mathrm{~mm}$ e o coeficiente de tanque para o período foi de 0,78.

BLACK et alii (1970̣̣) compararam a evapotranspiração do feijoeiro estimada pelo método de Penman-Montejth: (1965) e a evapotranspiração medida com um lisīmetro de pesagem. A evapotranspiração de referēncia foi em média $7,3 \mathrm{~mm} \mathrm{dia}^{-1}$, incluindo dois perīodos de secagem do solo, sendo que variou de $2,5 \mathrm{~mm} \cdot \mathrm{dia}^{-1}$ a $13,5 \mathrm{~mm} \cdot \mathrm{dia}^{-1}$. Durante o perỉodo de secamento, com o decréscimo da āgua disponível, a relação entre a evapotranspiração real e a evapotranspiração de referēncia, decresceu para 0,14 no primeiro período de secamento e para 0,20 no segundo período.

Segundo DOORENBOS e KASSAN (1979) a cultura do feijoeiro em média consome de 300 a $500 \mathrm{~mm}$ de água durante o seu ciclo de desenvolvimento, quando em condições de ampla disponibilidade hĩdrica no solo.

Alēm de determinar o consumo médio de āgua para uma cultura com a finalidade de projetar sistemas de irrigação e caracterização do potencial de plantio de determinadas regiões, em função das condições de precipitação e de disponibilidade hĩdrica, a determinação do comportamento da cultura frente a períodos de escassez de āgua no so10 è de grande importāncia, pois atravēs deste estudo podem-se selecionar variedades e também ëpocas de plantio de acordo com as características da região, procurando minimizar os custos de produção. 
Objetivando este tipo de estudo STANSELL e SMITLE (1980) estudaram as relações hîdricas do feijoeiro na estação da primavera e outono em três anos distintos. 0s diferentes tratamentos consistiram na irrigação da cultura durante os estādios de prē-florescimento, florescimento e pös-florescimento, quando o tensiōmetro instalado a uma profundidade de $10 \mathrm{~cm}$ acusava uma tensão de umidade no solo de $-0,025 \mathrm{MPa}$; $-0,05 \mathrm{MPa}$ e $-0,075 \mathrm{MPa}$. Os demais tratamentos consistiram em irrigar a cultura quándo a tensão de umidade alcançada $-0,075 \mathrm{MPa}$ em uma das três fases. A maior produção foi alcançada com tratamento de $-0,025 \mathrm{MPa}$ sen do que a mesma foi reduzida em 41 e $47 \%$ para os tratamentos de $-0,050$ e -0,075 $\mathrm{MPa}$, respectivamente. 0correu uma redução de 18 a $25 \%$ quando o tratamento de $-0,075 \mathrm{MPa}$ foi aplicado em um dos estádios reprodutivos. Para este tratamento não existiu diferença de sensibilidade dos diversos estādios, ao défice hîdrico. A relação média entre a evapotranspiração e a evaporação do tanque foi de 0,72 para o tratamento de $-0,025$

-. MPa de 0,55 para o tratamento de -0,050 $\mathrm{MPa}$ e de 0,49 para o tratamerito de $-0,075 \mathrm{MPa}$.

MAURER et alii (1969) determinaram que as plantas de feijoeiro que foram irrigadas quando o solo atingiu $88 \%$ da água disponível tiveram um desenvolvimento mais rápido, foram maiores e mais produtivas do que as plantas que foram irrigadas quando o solo atingiu $60 \%$ e $32 \%$ de sua āgua disponīvel. No tratamento sem défice hîdrico, as plantas exigiram 100 litros de água para produzir $280 \mathrm{~g}$ de matéria seca; no tratamento com nīveis intermediārios de āgua, as plantas exigiram 87 litros de água para formar $206 \mathrm{~g}$ de matéria seca e no tratamento de maior deficiência hîdrica exigiram 69 litros para produzirem $72 \mathrm{~g}$ de matēria seca. 
VEGA e CANTU (1982), dando um tratamento de umidade à cultura do feijoeiro, que consistiu na irrigação cada vez que a quantidade de āgua no solo alcançava 60 a $70 \%$ da quantidade total de água dis ponível às plantas na camada de solo explorado pelas. raízes da cultura, determinaram que o consumo total de água foi de $212 \mathrm{~mm}$ nos 95 dias de desenvolvimento da cultura. A eficiēncia do uso de āgua foi de 0,39 gramas de grãos por litro de água evapotranspirada.

MILLAR e GARDNER (1972), acompanhando as respostas das plantas de feijoeiro em períodos de secamento do solo,quantificaram os parāmetros que influenciavam este comportamento, ou seja: potencial de āgua no solo, potencial de āgua na planta, resistência eștomática, taxa de transpiração e indices fenológicos. Mostraram que a taxa de transpiração reduziu-se rapidamente quando o potencial de água no solo a $30 \mathrm{~cm}$ diminuiu para valores abaixo de $-0,025 \mathrm{MPa}$, quando o potencial de āgua no solo atingiu $-0,040 \mathrm{MPa}$ a taxa de transpiração foi reduzida em torno de $50 \%$ em relação àquela a-0,025 $\mathrm{MPa}$. Quando o potencial da āgua no solo diminuiu de $-0,028 \mathrm{MPa}$ para $-0,040 \mathrm{MPa}$ a taxa de produção de matéria seca reduziu-se em torno de $47 \%$. Segundo os autores, para regiões com limitações hídricas e onde o clima não tem uma variabilidade muito grande de ano para ano, seria de grande importāncia conhecer a re lação entre o potencial da água no solo e a taxa de crescimento e desen volvimento das culturas, para o auxîlio dos programas de irrigação.

MUIRHEAD e WHITE (1981) relacionaram o potencial de água no solo e o rendimento da cultura do feijoeiro. Os autores estudaram a influência do período em que a cultura tinha seu desenvolvimento 
em condições de baixo potencial de água no solo, no rendimento final da cultura. Os valores de potencial de água no sclo variaram de $-0,1$ a $-1,0 \mathrm{MPa}$, nas profundidades de 10,30,50 e $70 \mathrm{~cm}$ de solo. Determinaram para as condições estudadas, que o potencial da água no solo a. 50 e 70 $\mathrm{cm}$ de profundidade, mesmo durante os períodos críticos do feijoeiro (prē-florescimento e enchimento de grãos) não estiveram relacionados com a produção de vagens. Entretanto, a duração do perĩodo ( $n$ ọ de dias) em que o défice hîdrico permaneceu abaixo de $-0,5 \mathrm{MPa}$ na profundi dade de $30 \mathrm{~cm}$, explicou $77 \%$ da variação da produção de vagens, como também o coeficiente de determinação era sempre alto quando relacionavam o período em que a cultura se desenvolvia em condições de potenciais de água no solo abaixo de $-8,0 \mathrm{MPa}$ a $10 \mathrm{~cm}$.

Com a finalidade de caracterizar grupos de variedades quanto a sua sensibilidade à seca, SILVEIRA et alii (1981) avaliaram a resistência à seca de oito cultivares pertencentes ao grupo "Preto" e seis cultivares pertencentes ao grupo "Mulatinho" semeados em seis datas de plantio. Os tratamentos de défice aplicado à cultura foram baseados no número de dias em que a cultura permanecia com a umidade do solo abaixo de $25 \%$ do total da água disponível quando em capacidade de campo. Fazendo uma correlação simples entre o nūmero de dias em que a cul tura permanecia em estresse hĩdrico (estimado pelo balanço hîdrico) e o rendimento final das variedades, determinaram que a variação do rendimento foi explicada em $67 \%$, em média, pelo número de dias que a cultura permaneceu em défice hĩdrico. A medida que o número de dias de estresse 
hỉdrico aumentou, o rendimento diminuiu, sendo que a média dos rendimentos dos grupo "Mulatinho" foi maior que a média do grupo "Preto". Segundo os próprios autores, apesar do número de dias de estresse hîdrico explicar $67 \%$ da variação do rendimento seria conveniente realizar o estudo utilizando somente uma data de plantio, para eliminar 0 efeito "data de plantio".

\subsubsection{Na planta}

Segundo SCHOLANDER et alii (1965), a grande maioria das plantas vasculares tem o seu potencial de água variando de $-0,5$ e $-8,0$ $\mathrm{MPa}$. A variabilidade deste potencial depende de vários fatores, princi palmente da umidade do solo e das condições atmosféricas, mas comumente a variação diurna estā na faixa de $-1,0$ a $-2,0 \mathrm{MPa}$. Para a cultura do feijoeiro as faixas de potencial de āgua da folha comumente encontrada, para fins de estudo das relaçĩes hỉdricas foram diferentes, segundo vărias condições e autores.

KANEMASU e TANNER (1969a) em estudo do comportamento estomātico determinaram potenciais de āgua da folha de aproximadamente -1,40 MPa no campo e -1,2 MPa em casa de vegetação. MILLAR e GARDNER determinando a influência do potencial de āgua na planta sobre a produção de matēria seca caracterizaram potenciais de aproximadamente -1,2 MPa. O'TOOLE et alii (1977), estudando a relação entre a fotossintese e estresse hĩdrico em plantas crescendo em casa de vegetação, determinou potenciais de 0,0 a -1,0 MPa. HOFFMAN et alii (1978), estudando os elementos do meio no crescimento das plantas com relação à tolerançia das 
mesmas frente a condições de salinidade em vasos, determinaram potencial total, osmótico e de pressão, que alcançaram $-1,18 \mathrm{MPa}$, -1,65 MPa e 0,42 MPa, respectivamente. RESENDE et alii (1981), verificando a influência da frequência da irrigação em condições de campo sobre parâmetros hídricos e de crescimento da planta, determinaram poten ciais mínimos de potencial de pressão do xilema de aproximadamente $-1,18$ MPa. VAN VOLKENBURCH (1981), verificando o papel do potencial osmótico da āgua e da luz na expansão da folha, quando as plantas cresciam em soluções nutritivas, encontrou potenciais de $-0,16 \pm 0,9 \bar{a} \cdot-0,36 \pm 0,7$ MPa para o potencial total; de $-0,86 \pm 1,2$ a $1,06 \pm 0,4 \mathrm{MPa}$ para 0 potencial osmótico e de $0,5 \pm 1,2$ a $0,84 \pm 0,8 \mathrm{MPa}$ para potencial de pres são. JENSEN (1981), quando conduziu plantas em soluções nutritivas com vārias concentrações, determinou potenciais da água no xilema de $-0,67$ $\mathrm{a}-1,28 \mathrm{MPa}$ e potenciais osmóticos de $-1,06 \mathrm{a}-1,46 \mathrm{MPa}$.

JENSEN (1981) estudou a influência do estresse hîdrico causado em plantas de feijoeiro por duas soluções de diferentes concentrações. As plantas cresciam em solução nutritiva com potencial de $-0,07 \mathrm{MPa}$; a partir do florescimento os tratamentos diferenciais foram de $-0,07 \mathrm{MPa} ;-0,25 \mathrm{MPa}$ e $-0,45 \mathrm{MPa}$. Com estes tratamentos, quando 0 potencial de āgua na folha estava entre $-0,7 \mathrm{MPa}$ e $-0,9 \mathrm{MPa}$ ocorreu 0 fechamento estomático e quando apresentaram-se murchas o potencial de āgua na folha foi de $-1,0 \mathrm{MPa}$. Fazendo uma relação entre a condutância estomática da face inferior da folha e o seu potencial de pressão, notou-se que a condutância aumentou com o acrēscimo do potencial de pressão atē quando o mesmo atingiu o valor de $-0,3 \mathrm{MPa}$ e a partir deste pon to, permaneceu constante. Isto indica que o potencial da folha não 
reflete fielmente o estado de hidratação das cēlulas guardas.

Com relação a períodos de défice hĩdrico durante 0 desenvolvimento vegetal, mais precisamente da influência do estado energético da água na planta, os mecanismos de sobrevivência se manifestam segundo as espécies e estádios de desenvolvimento. 0 escape de perīodos críticos à seca pode ser conseguido através de um desenvolvimento mais rápido e ou por um desenvolvimento plástico, segundo TURNNER e BEGG (1981) e LAWN (1982 a, b, c.).

Para o feijoeiro, os estādios críticos do desenvolvimento em relação à seca são o prē-florescimento, florescimento e enchimentos de grãos (DOORENBOS e PREVITT, 1975), nos quais a atuação do défice hĩdrico causarā uma redução nos parāmetros de rendimento, como número de vagens por planta (JANES, 1948; ' KATTAN e FLEMING, 1956; BURMAN e BOHMONT, 1961; GODOY, 1966; EL NADI, 1969; MAURER et alii, 1969;FISCHER e WEAVER, 1974; MAGALHAES e MILLAR, 1978; MAGALHAES et alii, 15;9), e número e peso de grãos por vagens (JANES, 1948; KATTAN e FLEMING, 1956; BURMAN e BOHMONT, 1961; GODOY, 1966; MAURER et alii, 1969; MAGALHAES e MILLAR, 1978).

Com respeito à plasticidade de desenvolvimento para a cultura de feijoeiro existe pouca bibliografia a respeito. Para a cultura com boa disponibilidade hídrica no solo, SILVEIRA et alii (1980), estudando as respostas de duas variedades (Tambó e rio Tibagi)com relação à idade das plantas na floração e quanto ao pegamento de flores, mostraram que as variedades apresentaram perĩodos de floração de 19 a 24 dias respectivamente, e que, para ambas as cultivares, a relação entre a percentagem de pegamento ou vingamento de flores e o nūmero 
de grãos por vagem decresceu à medida que a idade de floração aumentou, sendo que as polinizações ocorridas até o quarto dia de floração foram aquelas que tiveram maior probabilidade de êxito; a partir desde dia o abortamento das flores cresceu continuamente até atịngir 100\%.

Para constatar se somente as primeiras flores formadas na planta de feijoeiro eram capazes de produzirem vagens ou se um mecanismo externo ou hormonal limitava o nümero de vagens aptas a serem colhidas, BINNIE e CLIFORD (1981) submeteram sete variedades de feijoeiro a diversos tratamentos de remoção de flores, constatando que todas as flores estiveram aptas a produzirem vagens, demonstrando que tal.vez a produção de vagens por todas as flores tenha uma limitação de vido ao suprimento de assimilados, a influência hormonal ou a combinação destes fatores.

0 citado estudo é muito importante sob o ponto de vista agronômico, pois atravēs dele e com estudos suplementares, submetendo as variedades ao estresse hídrico, pode-se identificar mais facilmente aquelas que possuem um perîodo maior de florescimento ou plasticidade de desenvolvimento, fato que pode auxiliar o melhoramento genético visando aumentar maior tolerāncia à seca.

Outro mecanismo apresentado por vārias leguminosas para escapar a períodos de estresse hîdrico é o movimento paraheliotrópico, o qual serve para diminuir a temperatura da folha sob estresse e presumivelmente evitar novas perdas de āgua; o grau de manifestação deste mecanismo segundo LAWN (1982 a, b e c) è diferente segundo espēcies e variedades. 
Segundo TURNER (1982), o mecanismo que comanda esta variação do āngulo das folhas está localizado na basé do folíolo, mais precisamente no pulvĩnulo, e as cēlulas são semelhantes às cēlulas buliformes das gramineas que provocam o enrolamento das folhas por per da de turgidez, diminuindo assim a ārea foliar "ativa".

DUBETZ (1969) estudou o fenômeno de paraheliotropismo em folhas de feijoeiro condicionadas ao estresse hĩdrico. Apōs trinta dias de emergência o solo deixou de receber irrigação e alcançou tensão da āgua de $-0,8 \mathrm{MPa}$. Nestas condições entre .0 30̣ e 40ọ dia, onde as temperaturas māximas variaram de $31^{\circ} \mathrm{C}$ a $36^{\circ} \mathrm{C}$, as plantas apresentaram o fenōmeno de paraheliotropismo. Este processo foi reversīvel, sendo que as folhas voltaram à posição anterior no inĩcio do dia, e este comportamento somente foi observado nas plantas estressadas. 


\section{MATERIAL E METODOS}

\subsection{Local.}

Os dados foram obtidos na ārea experimental do Departamento de Física e Meteorologia da Escola Superior de Agricultura "Luiz de Queiroz"/USP.

As coordenadas geogräficas do local são: latitude $22,70^{\circ}$ sul, longitude $47,63^{\circ}$ oeste e altitude de 586 metros (Município de Piracicaba, Estado de São Paulo).

0 clima desta região é do tipo mesotērmico Cwa (Sub tropical ümido com estiagem no inverno). A temperatura do mês mais frio é inferior a $18^{\circ} \mathrm{C}$ e a do mês mais quente è superior a $22^{\circ} \mathrm{C}$. Esse tipo $\mathrm{cli}$ mātico, segundo CAMARGO et alii (1974), ē denominado de "Tropical de altitude". 
A ārea em que foi instalado o experimento possui 0 solo descrito e classificado, segundo RANZANI et alii (1966), como pertencente à série Luiz de Queiroz, terra roxa estrutura, tendo como material de origen rochas eruptivas bāsicas. De acordo com a classificação americana (E.U.A., 1975), é um Oxic Paleudalf.

\subsection{Variedades}

Foram utilizadas duas variedades de feijoeiro (Phaseolus vulgaris), sendo ambas de hábito de crescimento indeterminado do tipo II, segundo classificação do CIAT (s.d.). Uma das variedades foi 0 "Aroana 80" que, em média, tem o inīcio de florescimento aos 35-40 dias apōs a emergência. A duração do perĩodo de desenvolvimento (emergênciamaturação fisiológica) è em média de 90-100 dias. A outra variedade utili zada foi a "Aeté 3 " que, em média tem o inīcio de florescimento com 30-35 dias apōs a emergência. A duração do seu período de desenvolvimento (emergência-maturação fisiológica) é de 90-95 dias,segundo descrição das variedades pelo Boletim Técnico do IAC (1982).

A densidade de plantio foi de 200.000 plantas/ha, semeadas manualmente com um espaçamento entre plantas de $0,1 \mathrm{~m}$ e entre linhas de 0,5m. Sempre que necessārio, fez-se aplicação de inseticidas, fungicidas e capinas.

A disposição das parcelas referentes aos tratamentos aplicados è mostrado na figura 1 . 


\subsection{Tratamentos Utilizados.}

Os tratamentos utilizados nas determinações foram consti tuídos por:

- Variedades de feijoeiro (Phaseolus vulgaris L.) "Aetê 3" e "Aroana 80".

- Trēs épocas de plantio, sendo:

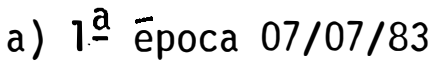

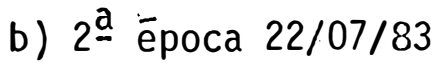
c) 3ㄹ ēpoca 04/08/83

- Tratamentos diferenciais de irrigação:

a) Cada variedade em cada época de plantio teve um tratamento conduzido em condições de altos valores de água disponível no solo durante o ciclo todo de desenvolvimento.

b) Cada variedade em cada época de plantio sofreu um pe rīodo de deficiēncia hỉdrica no solo, provocada atravēs da interrupção da irrigação por um período de dezessete dias a partir de 25 de setembro. No período considerado a primeira época de plantio encontrava-se no perīodo de pré-maturação fisiológica; a segunda época no estádio de formação e desenvolvimento de vagens; a terceira época no estádio de florescimento.

A localização dos tratamentos dentro da ārea experimental estā representada na figura 1 . 


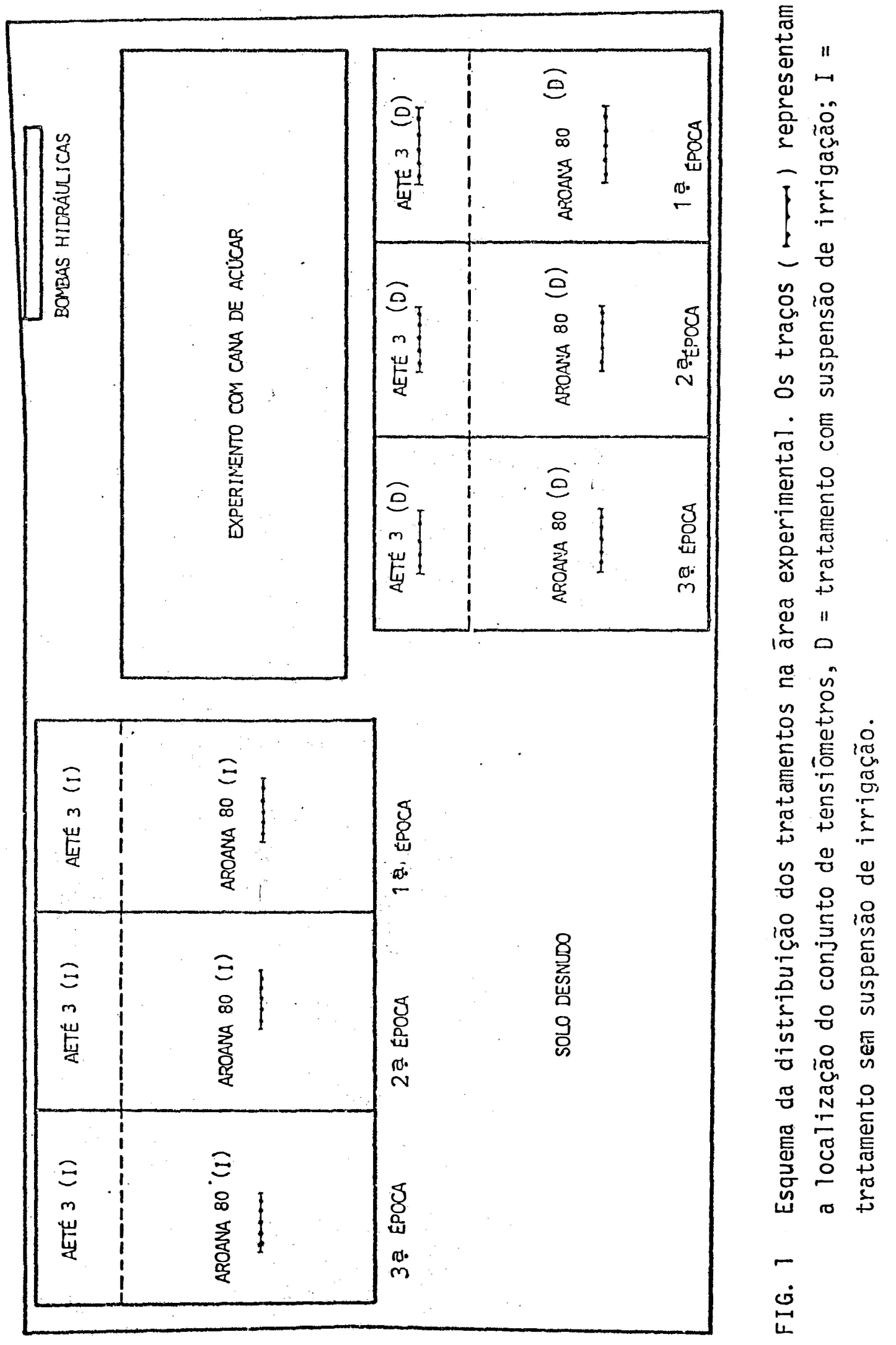




\subsection{Determinação dos Parâmetros Relacionados ao Fluxo de Agua}

Durante todo o ciclo de desenvolvimento do feijoeiro foram realizados balanços hîdricos em condições de campo para a determinação da evapotranspiração das culturas (ETc), nos tratamentos com e sem interrupção da irrigação na Aroana 80 e nos tratamentos com interrupção da irrigação na Aetē 3. Nesse mesmo perĩodo, foram feitas determinações do teor de água disponível no solo, bem como de evapotranspiração segundo o método de PENMAN (1948) de acordo com os critérios discutidos em itens seguintes, sendo que a determinação do ūltimo parāmetro citado foi realizada apenas para se obter um valor de referência.

Durante o perīodo de interrupção da irrigação, a ēem da medida diāria do potencial matricial de āgua no solo, foram determinados os potenciais de ãgua na folha nos tratamentos em que houve tentativa do estabelecimento de défice hî́d'ico acentuado. Por problemas de disponibilidade de equipamentos, o potencial total de āgua na folha $\left(\psi_{t}\right)$ foi determinado somente na variedade Aroana 80; os componentes de $\psi_{t}$, potencial osmötico $\left(\psi_{0}\right)$ e a somatöria do potencial osmōtico e matricial $\left(\psi_{0+m}\right)$, foram medidos nas duas variedades, mas por problemas de conservação das amostras, as determinações não puderam ser realizadas em todos os dias do período de estabelecimento do défice hídrico, sendo que os valores de $\psi_{0}$ e $\psi_{\text {otm }}$ foram determinados somente nos primeiros dias e para alguns dias do período, respectivamente.

Nesse período de interrupção da irrigação foram realiza das medidas de resistência estomātica e de fluxo transpiratōrio nas duas variedades e nos tratamentos com deficiência hîdrica. 
métodos adotados relativos a esses parāmetros.

\subsubsection{Balanço hîdrico no campo}

Para o cálculo da evapotranspiração māxima e evapotranspiração real utilizou-se o mētodo do balanço hīdrico no campo. 0 balanço hîdrico em um volume de solo é baseado na lei da conservação das massas. A saîda e entrada de água no volume do solo com profundidade "Z", variando de 0 (zero) a "Z" em um periodo de tempo definido entre $t_{1}$ e $t_{2} \quad \bar{e}$ descrita pela equação:

$\int_{t_{1}}^{t_{2}} p d t+\int_{t_{1}}^{t_{2}} i d t-\int_{t_{1}}^{t_{2}}$ edt $\pm \int_{t_{1}}^{t_{2}} q d t= \pm \int_{0}^{z} \int_{t_{1}}^{t_{2}} \frac{\partial \theta}{\partial z} d t \cdot d z$

onde:

p - intensidade de precipitação pluviométrica;

i - intensidade de irrigação;

e - intensidade de evapotranspiração;

q. - intensidade de percolação profunda ou ascensão capil ar em "Z";

$r$ - intensidade de escorrimento superficial;

$\theta$ - umidade do solo.

A "Irrigação" foi determinada atravēs da amostragem

da ägua adicionada (em número de duas por dose de irrigação por tratamento), feitas aleatorïamente junto ao conjunto de tensiômetros, com recepientes de ārea de captação conhecida. As irrigações por aspersão foram feitas de acordo com as necessidades dos tratamentos diferenciais, com um volume de āgua suficiente para elevar a umidade do solo à 
condição de capacidade de campo ou prōximo a ela, nas camadas de maior absorção de āgua pelas raîzes.

Foi desprezado o "Escoamento superficial", pois as condições do terreno quanto à sua inclinação e a taxa de infiltração. do solo no local do experimento permitem este procedimento, sem que acarrete erros significativos.

A obtenção da "Variação de āgua" no volume de solo considerado, foi feita por integração dos valores do conteúdo de ãgua nos $675 \mathrm{~mm}$ superiores do perfil do solo. Para a determinação da umidade em cada camada do perfil utilizou-se uma curva de retenção de umidade elaborada com valores de umidade volumétrica, sendo as amostras coletadas das camadas de $0-15 ; 15-30 ; 30-45 ; 45-60$ e $60.75 \mathrm{~cm}$ e os valores de potencial matricial da água obtidos com os tensiōmetros instalados nas profundi dades limites das camadas de extração das amostras. Foram obtidas duas amostragens com duas subamostras, a intervalos de tempo variāveis durante a condução do experimento entre 5 a 10 dias. A umidade foi determinada pelo mëtodo gravimētrico e a umidade com base em peso seco foi transformada em umidade com base em volume.

A densidade global foi determinada atravēs de três amostras por camada, com o auxîlio de cilindros volumétricos.

. A "Percolação profunda" foi estimada com base na equação geral que se tem utilizado descreve o fluxo de água em um perfil de solo (DARCY, 1856) como segue:

$$
q=-K(\theta) \cdot\left|\frac{\partial H}{\partial Z}\right|_{Z}
$$


onde:
$\left|\frac{\partial H}{\partial Z}\right|_{Z}$ é o gradiente de potencial hidrāulico operado através do plano $K(\theta)$ è a condutividade hidrāulica do solo.

A condutividade hidráulica do solo foi determinada no 10cal do experimento pelo mētodo de LIBARDI et alii (1980), sendo a relação entre a condutividade hidrāulica e a umidade do solo dada por:

$$
K(\theta)=K_{0} \cdot e^{\gamma\left(\theta-\theta_{0}\right)}
$$

onde

$$
\begin{aligned}
& \gamma \rightarrow \text { é o coeficiente ángular da reta de ln K versus } \theta \\
& K_{0} \rightarrow \text { condutividade hidrāulica no tempo zero de drenagem } \\
& \theta_{0} \rightarrow \text { umidade volumétrica de saturação no tempo zero de drenagem } \\
& \theta \rightarrow \text { umidade volumétrica no instante considerado }
\end{aligned}
$$

Para o solo em questão tal equação pára $67,5 \mathrm{~cm}$ apresentou como:

$$
K(\theta)=0,188 \cdot e^{272,590(\theta-0,367)}
$$

Os potenciais matricial e hidrāulico foram obtidos com 0 auxīlio de tensiōmetros atravēs de leituras diārias. 0 quociente da diferença entre os potenciais hidráulicos nas profundidades de 60 e $75 \mathrm{~cm}$ pe1a distância entre as duas profundidades, foi considerado como o gradiente de potencial da água no plano a $67,5 \mathrm{~cm}$ de profundidade. 
Para se obter os valores diārios de drenagem profunda estimaram-se os valores de umidade do solo atravēs da curva caracterīstica da água no solo, a qual foi determinada, para baixas tensões de umidade do solo atravēs da relação entre a umidade média obtida por gravime tria na cama onde se localizava o. tensiōmetro, com os valores dos potenciais matriciais estimados pelas leituras dos tensiômetros. De posse de todos estes parâmetros foi obtido o termo "Percolação profunda" pelo pro duto da condutividade hidrāulica determinada a 67,5am pelo gradiente do potencial hidrāulico entre $60-75 \mathrm{~cm}$, para o perīodo considerado.

Em cada parcela referente a cada tratamento foi instalado um conjunto de dez tensiōmetros com manômetros de mercürio, localizado no centro da parcela, sendo as profundidades dos tensiōmetros de 15, $30,45,60,75,90,105,120,135$ e $150 \mathrm{~cm}$. Nos tratamentos de umidade que visaram dar condições ōtimas de desenvolvimento à cultura não foram instalados os conjuntos de tensiōmetros da variedade Aeté 3 e o momento de rega foi controlado pelo conjunto de tensiómetros localizados nas par celas da variedade "Aroana 80".

Para o cálculo da evapotranspiração pelo método do balanço hîdrico subdividiu-se o ciclo da cultura em perĩodos de trēs a cinco dias em mēdia. Após esta divisão calculou-se a evapotranspiração mēdia de períodos variāveis e sobrepostos, de preferência englobando os perĩodos de chuva com os de drenagem referente ao mesmo período. Em certos intervalos de tempo não foi possível calcular os valores da evapotranspiração, devido a uma super estimativa ou sub-estimativa da drenagem 
profunda. Para sanar esta deficiência, com os valores destes intervalos variāveis, determinou-se uma relação entre a evapotranspiração da cultura e aquela segundo PENMAN (ETC/ETP) para cada um desses intervalos, cons truindo-se uma curva em função dos dias apōs a emergēncia. Com os valores médios tomados dessa curva para intervalos de cinco dias, determinou-se o ETC para este mesmo intervalo com o auxîlio da ETp para o mesmo período. Este procedimento é satisfatōrio, pois os perīodos com falta de ETc ocorreram em épocas chuvosas, quando então a relação ETc/ETp segue uma tendéncia geral sem apresentar provavelmente desvios acentuados.

3.5.2. Evapotranspiração segundo o método de PENMAN

Foi utilizada a equação proposta por PENMAN (1948):

$$
E T p=\frac{\Delta}{\Delta+\gamma} \cdot H+\frac{\gamma}{\Delta+\gamma} \cdot E \bar{C}
$$

onde

ETp - evapotranspiração māxima (mm)

$\Delta$ - tangente à curva de saturação de vapor d'água $\left(m m .{ }^{0} C^{-1}\right)$

$\gamma$ - constante psicrométrica $\left(\mathrm{mm}^{\circ}{ }^{\mathrm{o}} \mathrm{C}^{-1}\right)$.

H - energia líquida disponível ao sistema (mm de evap.equivalente)

Ec - termo de evaporação (mm de evap. equivalente)

- 0 termo $\frac{\Delta}{\Delta+\gamma}$, ou coeficiente de correção, utilizado para a obtenção do termo energético, e o termo $\frac{\gamma}{\Delta+\gamma}$ ou coeficiente de correção utilizado para a obtenção do termo aerodināmico, foram determinados atra vēs dos valores da temperatura média do ar com o auxīlio de uma tabela 
elaborada com os valores de $\frac{\Delta}{\Delta+\gamma}$ e $\frac{\gamma}{\Delta+\gamma}$ e temperaturas mëdias diārias, (.OMETTO, 1981).

Para a determinação diāria de energia lĩquida disponīvel (H) utilizou-se uma equação determinada atravēs de equação linear simples entre a radiação global (RG) medida atravēs de um piranōmetro Eppley e tipo "branco e preto" com dez junções e constante de $3,55 \times 10^{-6} \mathrm{mVW}^{-1} \mathrm{~m}^{-2}$ e a radiação líquida obtida pelo balanço de energia feito na prōpria cul tura do feijoeiro em estāgio de máximo desenvolvimento e em condições de não restrição hỉdrica à cultura. Esta relação foi determinada através de 15 pares de dados ( $R G \times H$ ), obtendo-se um coeficiente de determinação de $r=0,982$.

Na determinação do balanço de energia utilizou-se um radiômetro para radiação líquida marca MIDDLETON não ventilado ccm uma constante de $28,173 \mathrm{mV} / \mathrm{cal} \mathrm{cm}{ }^{-2} \min ^{-1}$. Para a obtenção do fluxo de calor no solo utilizaram-se dois fluximetros em sērie marca MIDDLETON com constantes de 16,55 e $17,05 \mathrm{mV} / \mathrm{cal}^{\mathrm{cm}} \mathrm{cm}^{-2} \mathrm{~min}^{-1}$ para cada uma delas.

Os sinais elétricos desses equipamentos foram medidos com um potenciômetro (Cambridge Portable Potentiometer, fabricado pela Cambridge Instrument Company Limited, England) com sensibilidade de atē $0,0.1 \mathrm{mV}$.

Na determinação diāria do termo aerodinâmico (Ec) foi utị lizada a equação:

$$
E_{c}=(0,35+0,184 U) \cdot\left(e_{s}-e_{a}\right)
$$


onde

$\mathrm{U} \quad=$ velocidade do vento a $2 \mathrm{~m}$ acima da superfície evaporarte $\left(\mathrm{m} . \mathrm{s}^{-1}\right)$

$e_{s}-e_{a}=$ défice de saturação de vapor de ãgua do ar (mmHg)

A velocidade do vento a dois metros de altura acima da superfície evaporante foi determinada com um anemōmetro integrador ( $\mathrm{Km} /$ dia) marca FUESS modelo de canecas.

0 défice de saturação de vapor de āgua do ar foi obtido através do método e aparelho especificado no item 3.5.5.

\subsubsection{Cálculo da fração de āgua disponível (F.A.D.)}

Para o cálculo da F.A.D. utilizaram-se os valores de umidade $(\theta)$ estimada atravēs da tensiometria e as curvas características de umidade do solo para cada profundidade considerada. De posse desses valores calculou-se a F.A.D. pela fórmula:

$$
\text { F.A.D. }=\frac{\Theta-{ }_{\text {PMP }}}{{ }_{C C}-{ }^{\Theta_{P M P}}}
$$

onde

$\Theta_{\text {CC : }}$ - umidade da camada de solo a "capacidade de campo"

$\Theta_{\text {PMP }}$ - umidade da camada de solo no "ponto de murchamento permanente"

$\Theta \quad \rightarrow$ umidade da camada de solo observada no dia considerado

0 valor de $\Theta_{C C}$ foi estimado através da curva representativa da variação do teor de āgua $(\theta)$ em função do tempo, obtida após o solo ter sido saturado e coberto para evitar a evaporação da umidade da superfície. Quando os valores de $\Theta$ apresentaram pequena variação 
(aproximadamente de 0,005\%/dia) caracterizou-se esta umidade como sendo aquela da capacidade de campo e os valores correspondentes de potencial matricial de āgua no solo variaram em torno de 0,001 $\mathrm{MPa}$.

0 valor de $\Theta_{\text {PMP }}$ foi determinado submetendo amostras indeformadas de solo, coletadas em nümero de três por profundidade, a pres sões de 1,5 MPa na câmara de RICHARDS.

\subsubsection{Potencial da āgua na planta}

0 potencial da àgua na planta é determinado básicamente pé la concentração de solutos nos vacuolos das células, pela quantidade de substãncias hidratadas e pela pressão exercida pela parede celular e de acordo com a expressão:

$$
\psi_{\text {total }}=\psi_{\text {osmötico }}+\psi_{\text {pressão }}+\psi_{\text {matricial }}
$$

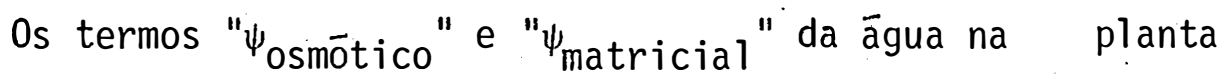
possuem,para efeito de estudos, sinal negativo. 0 termo "廿pressão" deve ser sempre positivo ou no máximo igual a zero.

0 potencial total e o desdobramento em seus componentes foram determinados por higrometria de par termoelétrico atravēs de equipamento marca Wescor constituĩdo de três câmaras de amostras modelo "C--52" e três cãmaras de inserção nas folhas, modificadas para conterem as amos tras retiradas das folnas e de um microvoltímetro higrométrico modelo "HR-33".

Antei iormente ao inĩcio das determinações fez-se um estudo para verificar o tempo necessārio para que a amostra entrasse em 
equilî́brio com a atmosfera das câmaras higromētricas.

Para a determinação do potencial total da água na folha $\left(\psi_{t}\right)$, os discos de tecido eram retirados das folhas superiores mais expandidas, evitando-se a amostragem em folhas sombreadas. 0 local de amostragem dentro de cada parcela era próximo à localização dos tensiōmetros.

Para cada determinação do potencial total da ägua na foTha no tratamento considerado foram utilizadas três câmaras e as amostras do tecido das folhas procediam de três plantas diferentes. Após a coleta as câmaras foram colocadas em ambiente com temperatura controlada.

As determinações do potnencial $\psi_{(0+m)}$ foram feitas atravës de amostras provenientes de três folhas de três plantas tomadas ao acaso dentro do tratamento. Estas três folhas foram acondicionadas em sacos de polietileno e imediatamente apōs a identificação imergidas por 30-60 se gundos em $\mathrm{N}_{2}$ liqquido e ao final do dia eram armazenadas sob temperaturas abaixo de $0^{\circ} \mathrm{C}$ atē que fossem utilizadas para a determinação do $\psi_{(0+m)}$. Para cada amostragem de um determinado horārio fez-se de duas a três determinações atravēs da retirada de pequenos discos do tecido foliar, con forme tēcnica descrita por SLAVIK (1974).

Na determinação do potencial osmótico $\left(\psi_{0}\right)$ utilizou-se as mesmas folhas da determinação do $\psi_{(0+m)}$. Para tanto, as amostras (três folhas) eram acondicionadas em um aparelino de metal com sistema perfurado de coleta de seiva e, com o aunîlio de uma prensa hidrāulica manual,eram submetidas a pressões de 20MPa. A seiva recolhida foi acondicionada em frascos de vidro e armazenadas sob temperaturas suficientemente baixas 
para manterem- se congeladas atē a determinação do $\psi_{0}$. Apōs retiradas do congelador as amostras eram deixadas a entrar em equilibrio com 0 ambiente utilizando-se então apenas pequena quantidade da mesma, suficiente para umedecer três discos de papel de filtro, os quais eram colocados em câmaras higromētricas distintas.

Do posse dos valores do $\psi_{t}$ e do $\psi_{(0+m)}$, com 0 auxilio da equação (8) determinou-se algebricamente o potencial de pressão.

3.5.5. Resistência estomática à difusão de vapor e taxa de transpiração

Paralelamente às medidas dos potenciais de ãgua na planta e no solo durante o estádio de secamento, determinou-se diariamente no período luminoso com o auxîlio de um porometro de equilíbrio dinâmico ("Steady State Parometer") marca LI-COR modelo LI-1600, a densidade do fluxo transpiratório e a resistência estomática à difusão de vapor de àgua na folha.

A amostragem para a determinação dos pontos dá curva representativa das variações desses parâmetros, ao longo do perĩodo lumino so, foi feita em oito plantas diferentes, sendo que em quatro delas as determinações foram reaiizadas na face dorsal e as quatro restantes na face ventral dos folíolos totalmente expandidos, localizados em posições de maneira a não estarem sofrendo sombreamento. 
3.5.6. Condições de demanda evaporativa da atmosfera

Para a caracterização da demanda evaporativa da atmosfera foram determinados o défice de saturação de vapor d'ãgua do ar e a radiação solar global.

0 défice de saturação de vapor d'água do ar foi determinado através dos valores de umidade relativa e temperatura do ar, regịstrados por um termohigrógrafo marca FUESS de registro semanal, com 0 auxîlio da tabela que relaciona os valores de temperatura do ar e tensão māxima de vapor sobre a āgua em mmHg $\left(e_{s}\right)$ apresentada por OMETTO (1981).

A determinação da radiação solar global estā descrita no item 3.5.2.

3.6. Determinações Fenolōgicas

3.6.1. Determinação dos estādios fenológicos

A caracterização dos estādios fenológicos foi feita atra vēs de vistoria diāria. Os critérios foram os mesmos adotados por FEHR e CAVINESS (1977), para a cultura da soja. 
3.6.2. Peso seco de plantas

Para a determinação do peso seco fez-se amostragem semanal de cinco plantas contidas em $0,5 \mathrm{~m}$ de linha, com três repetições por tratamento, em locais prōximos aos tensiōmetros. Apōs coletadas, estas plantas eram lavadas em āgua corrente. Apōs 0 acondicionamento (em sacos de papel, eram secadas em estufa de ventilação forçada, a uma temperatura de $75 \pm 5^{\circ} \mathrm{C}$ até atingirem peso constante. 
4. RESULTADOS

4.1. Relativos ao ciclo de desenvolvimento das culturas

4.1.1. Variação da água disponível do solo

A figura 2 mostra a variação da fração de ăgua disponīvel no solo (FAD) nas três épocas de plantio considerando.um perfil até a profundidade de $67,5 \mathrm{~cm}$. para a variedade Aroana 80 na parcela que não sofreu interrupção do suprimento de água no solo (I) e para as duas variedades utilizadas nas parcelas que sofreram interrupção na irrigação (D).

Verifica-se pelos dados, que houve pelo menos cinco perío dos distintos quanto aos valores de $F A D$ durante o ciclo de desenvolvimento das culturas. No primeiro periodo, que ocorreu atē o 500, 350 e 200̣ dia apōs a emergência na primeira, segunda e terceira épocas de plantio, respectivamente, a fração de āgua disponível manteve-se com valores médios entre 0,48 e 0,60 e sem grandes oscilações nas duas ūitimas épocas, com valores inferiores no tratamento que não sofreria posteriormente a intşirúpção da irrigação, enquanto que na primeira época 


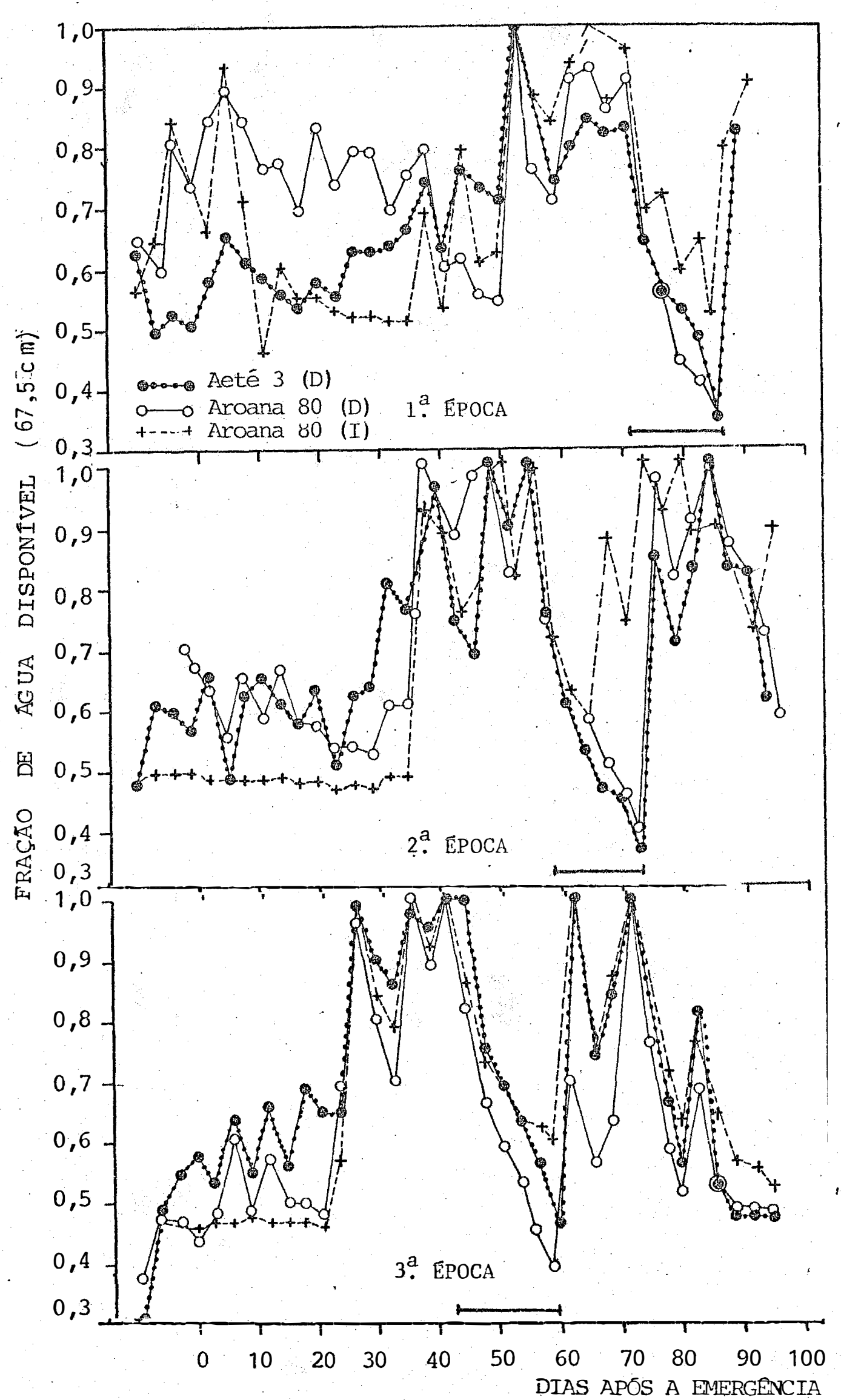

FIG. 2 - Frařũc da āgua disponivel (F.A.D.) para ds variedades AROANA 80 e AETE 3 nas trēs épo cas de plantio durante o ciclo de desenvolvimento da cultura. 0 intervalo ( representa o periodo sem irrigação. 
de plantio, os valores de FAD, além de se mostrarem em média maiores do que nas duas outras ēpocas, mostraram maiores oscilaçũes, principalmente no tratamento Aroana 80 (I). Em todos os casos houve tendência de ocorrerem maiores valores de FAD no tratamento Aroana 80 (D), excluindo-se o tratamento Aeté 3 (D) na terceira época.

0 segundo perīodo é caracterizado pelos altos valores de FAD ocorrendo até o 700, 550 e 40 dia após a emergência, na primeira, segunda e terceira épocas de plantio, respectivamente. Nesse período os valores oscilam entre 0,7 e 1,0 nos tratamentos que sofreriam interrupção da irrigação e 0,75 e 1,0 no Aroana 80 (I).

0 - terceiro período é representado pela interrupção do suprimento hîdrico do solo, caracterizando-se pela diminuição dos valores de FAD de modo mais drástico nos tratamentos Aroana 80 (D) e Aetē 3 (D), nos quais os valores diminuiram atē valores em torno de 0,35. nas duas épocas de plantio, enquanto na terceira época atingiram 0,39 para 0 Aroana 80 (D) e 0,46 para Aeté 3 (D). No Aroana 80 (I), os valores mînimos de $F A D$ atingidos foram $0,52,0,57$ e 0,60 para a primeira, segunda e terceira épocas de plantio, respectivamente.

0 quarto período, que se iniciou no 860,730 e 580 dia apōs a emergência na primeira, segunda e terceira épocas de plantio, res pectivamente, caracteriza-se por um aumento nos valores de FAD em todos os tratamentos, atingindo valores médios acima de 0,80 nas duas primeiras ēpocas, enquanto que na ūitima época de plantio foram atingidos valores acima de 0,74 nos tratamentos Aroana 80 (I) e Aetē 3 (D) e acima de 0,56 (mas com média acima de 0,70) no tratamento Aroana 80 (D). 
A determinação posterior de FAD mostrou valores médios inferiores em relação ao perīodo citado anteriormente nas duas ēpocas de plantio. Na segunda época, nos tratamentos que sofreram interrupção de irrigação a FAD diminuiu até pröximo de 0,6 entre 94-96 dias apōs a emer gência, quando o tratamento Aroana 80 (I) ainda sofreu um acréscimo. Na terceira época de plantio no 820 dia apōs a emergência a FAD, que mantinha uma tendência de diminuição apōs o 710 dia, se elevou e tornou novamente a diminuir até o final do ciclo nos três tratamentos, terminando com valor superior no Aroana $80 \mathrm{I}$.

4.1.2. Duração dos estādios fenológicos e acúmulo de matéria se$\mathrm{ca}$

A figura 3 representa a caracterização do inīcio e / ou final dos estādios fenológicos da cultura em função dos tratamentos aplicados.

Para a primeira época de plantio não ocorreram diferenças quanto à duração dos estādios e do ciclo todo, independente do tratamento aplicado.

$\mathrm{Na}$ segunda época de plantio as diferenças entre tratamentos aconteceram entre aquele que não sofreu a suspensão da irrigação e o que sofreu, isso para a variedade Aroana 80 , sendo que na variedade Aeté. 3 isto não aconteceu.

A terceira época comportou-se diferentemente da segunda época com respeito a influência do estresse hĩdrico na duração do ciclo da cultura; para a variedade Aroana 80 a duração do ciçı foi diferente 


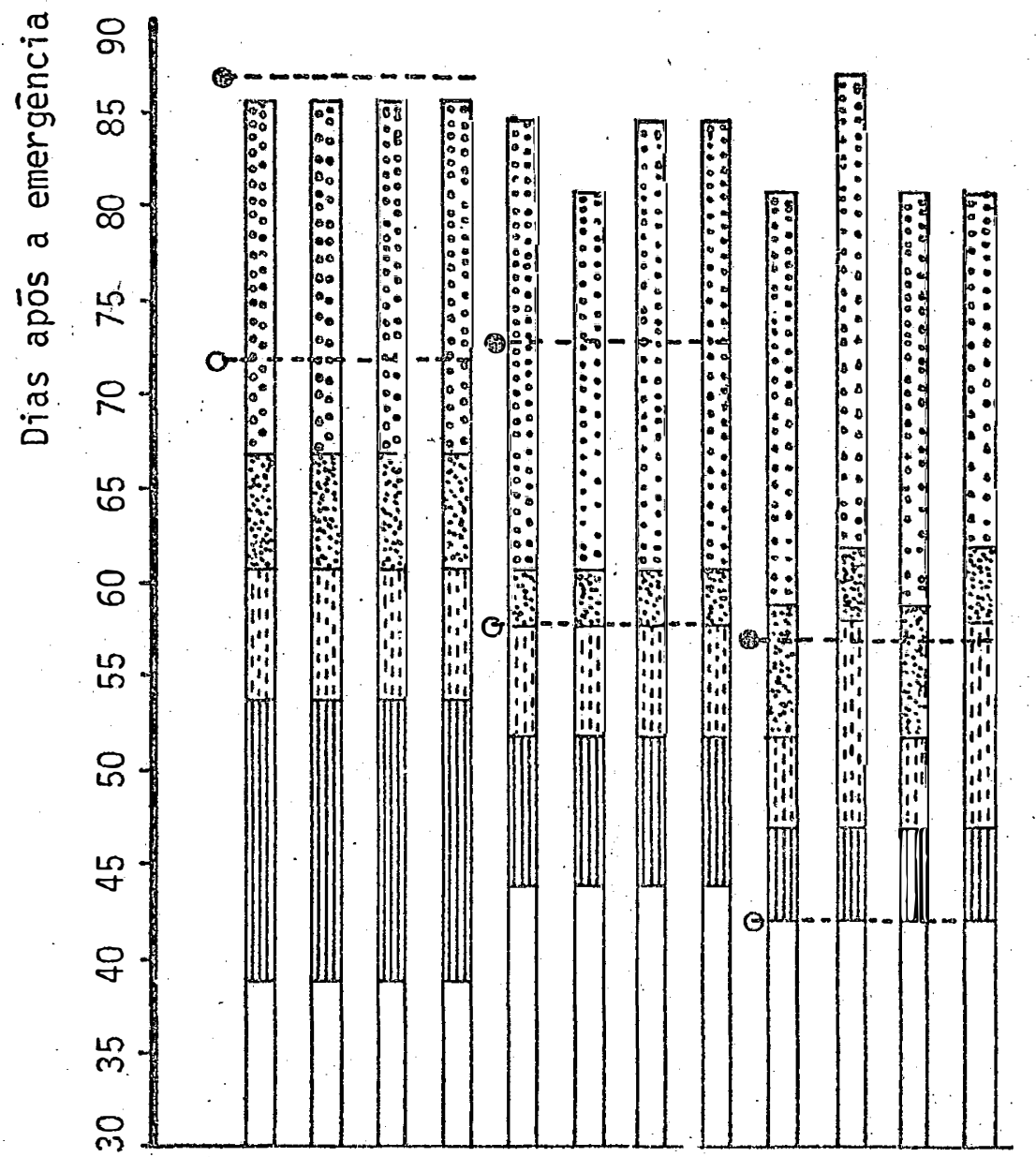

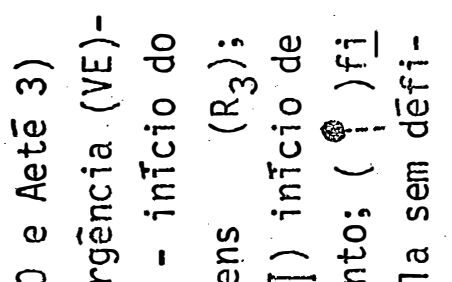

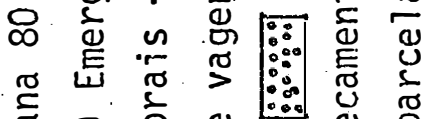

范

远

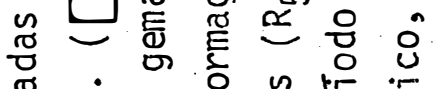

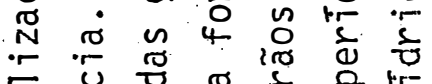

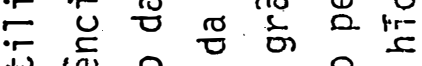

씩 임 웅 웅

n बे

吾 E E

ठृ

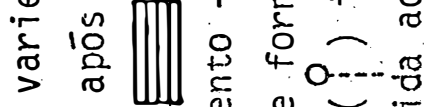

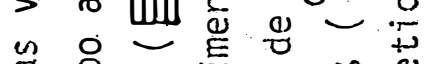

号萛

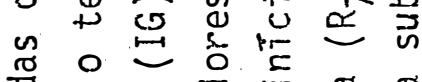

\%

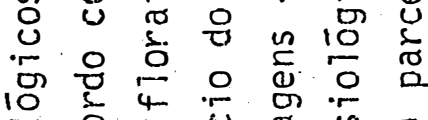

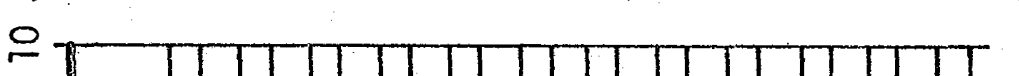

过 n

(ब E

\%

号. 吕至

䒠袋

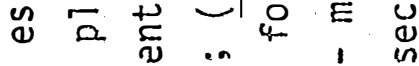

\%

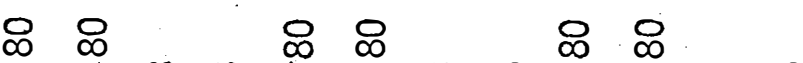

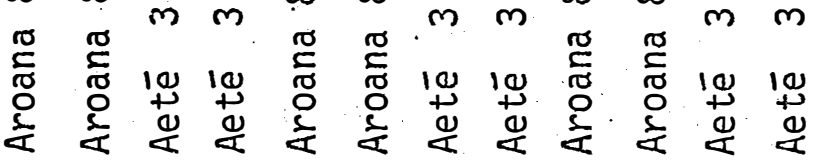

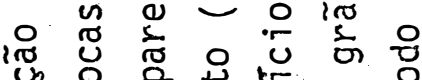

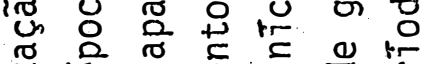

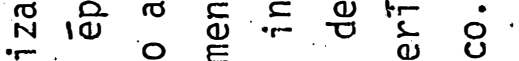

为 응 雚

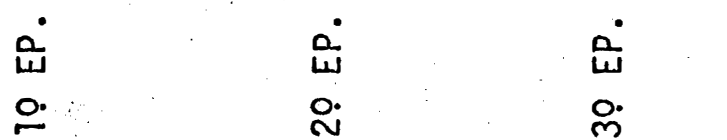

焉

m

尔 
enquanto que para a variedade Aetē 3 foi igual. Na segunda época Aroana 80 o estresse hĩdrico provocou uma redução no ciclo da cultura em relação ao tratamento sem suspensão da irrigação; na terceira ēpoca, no tratamentos com suspensão da irrigação, o ciclo da cultura teve um acréscimo de duração em relação ao tratamento sem suspensão da irrigação na mesma ēpoca de plantio.

A redução do ciclo na variedade Aroana 80 na segunda época de plantio em consequência da aplicação do tratamento de estresse hĩdrico foi devido a uma redução no estádio compreendido entre o inīcio de formação de grãos e a maturação fisiológica, estádio no qual suspendeuse a irrigação na referida parcela. Jā na mesma variedade, na terceira é-poca de plantio o acréscimo da duração do ciclo da cultura em consequên - cia da suspensão da irrigação, foi devido a um aumento no estádio compreendido entre o inīcio de florescimento e inīcio de formação de vagens e tambēm no perīodo compreendido entre o inīcio de formação de yrãos e a maturação fisiológica.

\subsubsection{Evapotranspiração}

As figuras 4,5 e 6 mostram a evapotranspiração acumulada para as três épocas de plantio da variedade Aroana 80 mantida sem deficiência hîdrica (I) e com interrupção da irrigação (D), bem como da Aetē 3.com intèrupção da irrigação. Na primeira época de plantio a eva potranspiração calculada pelo método de Penman (ETp) mostrou uma diferença relativamente ampla em relação à evapotranspiração calculada pelo método do balanço hídrico no campo (ĖTC) nos tratamentos atē por vulta do 650 


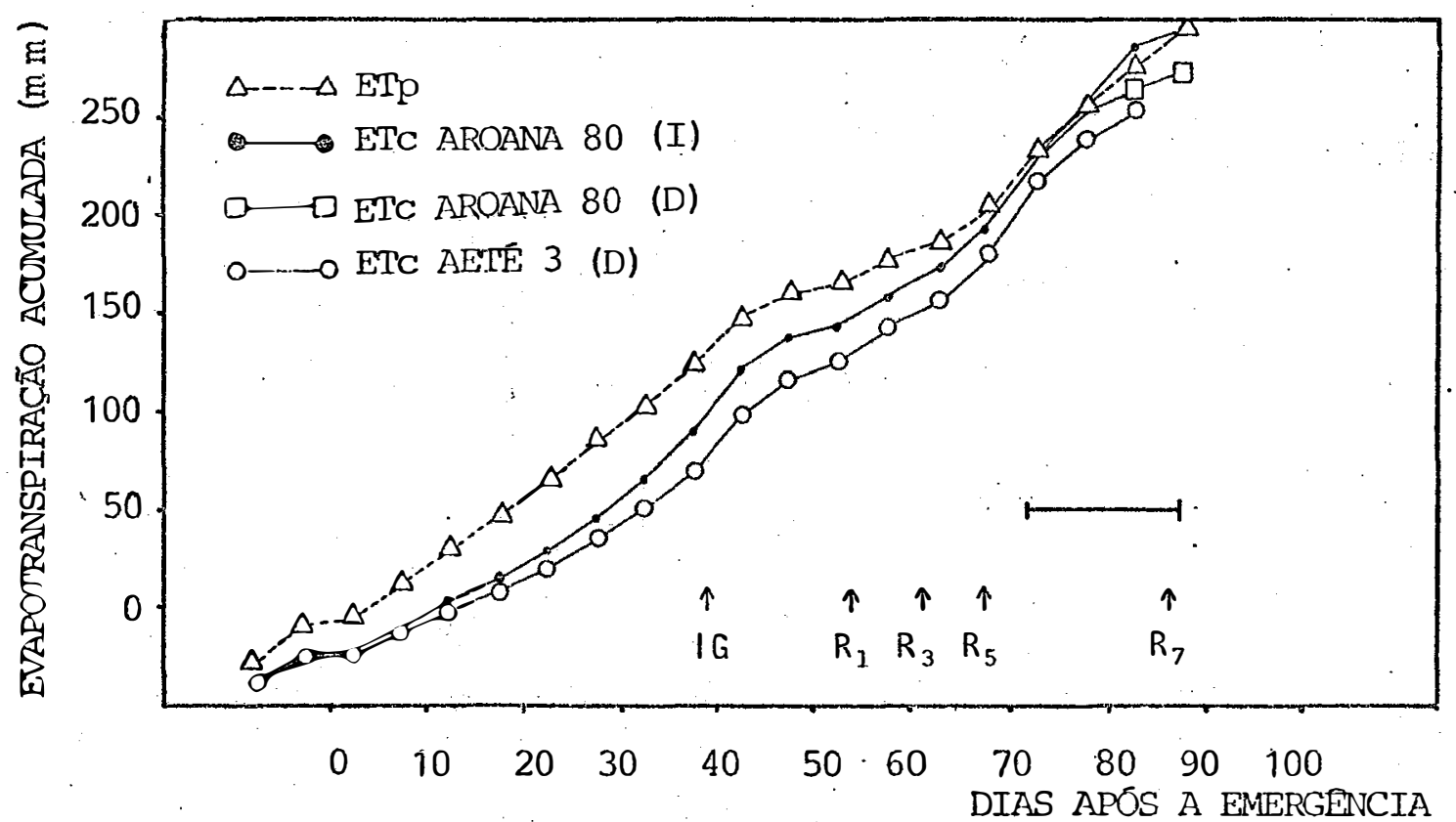

FIG. 4 - Evapotranspiração das culturas (ETC) e pelo método de Penman (ETp) nos diferentes tratamentos, na primeira época de plantio. As setas $(\uparrow)$ indicam 0 início de cada estādio da cultura, vide figura 3 , e o intervalo (—) è o período de suspensão da irrigação. 


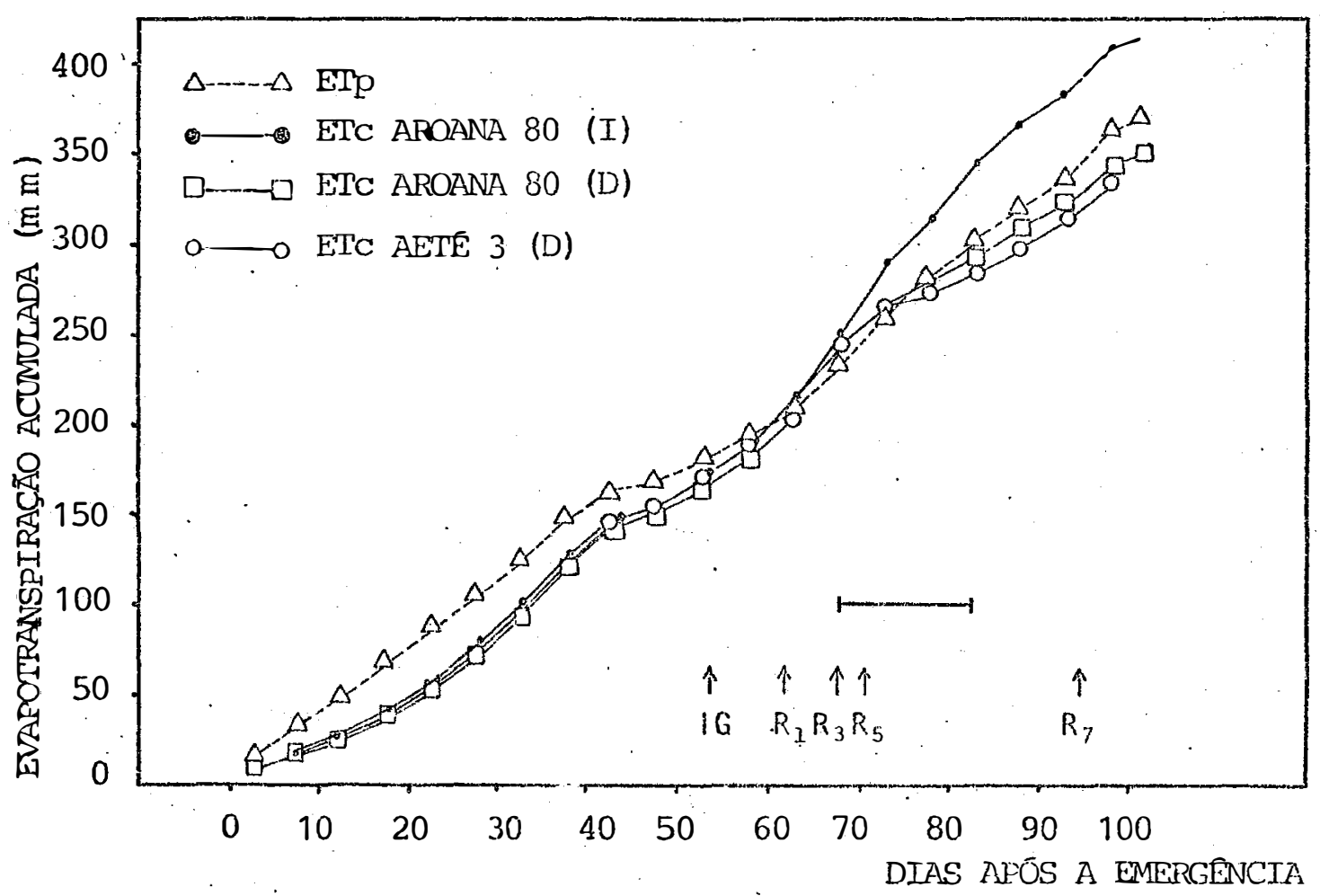

FIG. 5 - Evapotranspiração das culturas (ETC) e pelo método de Penman (ETP) nọs diferentes tratamentos, na segunda época de plantio. As setas $(\uparrow)$ indicam o início de cada estádio da cultura, vide figura 3 , e o intervato ( - ) è o perỉodo de suspensão da irrigação. 


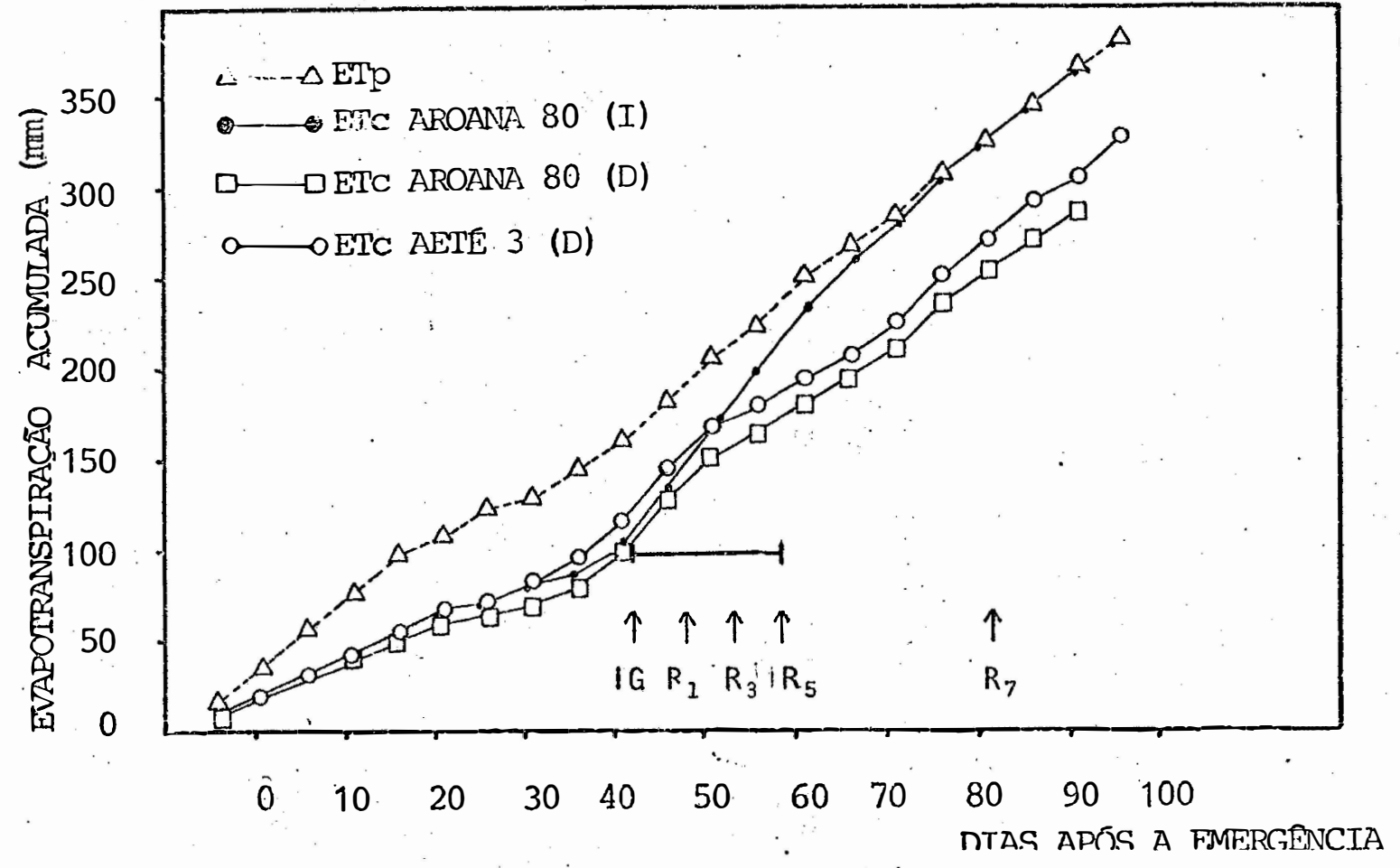

FIG. 6 - Evapotranspiração das culturas (ETC) e pelo método de Penman (ETp) nos diferentes tratamentos, na terceira época de plantio. As setas ( $\uparrow$ ) indicam.o início de cada estādio da cultura, vide figura 3 , e o intervalo ( - - ) . e o período de suspensão da irrigação. 
dia apōs a emergência. Essa aproximação com a ETp foi maior na variedade Aroana 80 que na variedade Aeté 3. A partir do 700 dia o tratamenro Aroana 80 (I) mostrou valores acumulados de ETc maiores do que os da ETp, enquanto que os demais tratamentos, sofrendo a influência do secamento do solo,mostraram uma taxa de perda de āgua inferior à da ETp. No ta-se, para os dois tratamentos Aroana 80 (D) e Aeté 3 (D), ainda na prị meira época, uma diminuição da taxa de perda de água entre o 40 e e 060 ̣ día apōs a emergência, sendo neste período onde ocorreu a menor taxa de perda de āgua. A maior taxa de perda ocorreu para todos os tratamentos entre o 30 e e o 40 ̣ e posteriormente entre o 650 e o 750 dia apōs a emer gência.

$\mathrm{Na}$ segunda época de plantio as diferenças entre a ETC de todos os tratamentos foram bem menores do que as ocorridas na primeira época até o 40 Q dia, a partir do qual a diferença foi progressivamente diminuida até o 570 dia quando os valores de evapotranspiração acumulada tornaram-se aproximadamente iguais. Apōs essa igualdade os tratamentos responderam às diferenças de āgua disponīvel no solo, sendo que a varieda de Aroana 80 (I) teve um grande acréscimo nos valores de ETc acumulada, os quais ultrapassaram bastante os valores de ETp acumulada. Os tratamentos Aroana 80 e Aeté 3 com deficiência voltaram a ter valores acumula los de ETC menores que os de ETP, sendo que a variedade. Aroana 80 mostrou valores mais altos de ETc acumulada. A diferença nos valores de ETc acumulada entre as variedades com o tratamento de imposição do défice hĩdrico foi quase que nula atē o fornecimento de āgua ao solo ser interrompido, a. partir do que ocorreu uma pequena diferença da perda de água entre as variedades estudadas, sendo maior para a variedade. Aroana 80 
que para a Aeté 3. A maior taxa de perda de água ocorreu entre o 60 e e 70 ọ dia e a menor entre o 420 e 0 530 dia apōs a amergência.

Para a terceira época de plantio, nos estágios iniciais de desenvolvimento da cultura ocorreu a maior diferença entre ETp e ETc acumulada e em nenhum tratamento nesta época de plantio a ETc superou os valores da ETp. A diminuição desta diferença ocorreu somente no tratamento Aroana 80 (I) a partir do 50 ọ dia após a emergência, sendo que para os demais tratamentos ela permaneceu quase constante com um ligeiro aumento desta mesma diferença para ambas as variedades. A partir do 750 dia após a emergência, os valores acumulados de ETc e ETp̣ igualaram-se e assim prosseguiram atē a maturação fisiológica. Para os tratamentos com deficiencia hîdrica a diferença entre os valores acumulados de ETc nas variedades Aroana 80 e Aetē 3, com valores superiores na primeira, foi iniciada nos primeiros dias após a emergência, permanecendo aproximadamente constante a partir do 300 dia apōs a emergência até a uaturação fisiológica. A maior taxa de acréscimo da ETc ocorreu entre o 400 e 0 50 ọ dia apōs a emergência e a menor taxa de aumento entre o 20 e e o 35 o dia.

A Tabela 1 mostra os valores da evapotranspiração acumulada em cada estādio da cultura como tambēm a evapotranspiração acumulada desde a emergència atē o inīcio e ou final do estādio em questão. Os valores māximos de ETc. acumulada em cada estādio foram atingidos a partir da emergēncia atē o inîcio da formação de gemas florais, excluindo-se o tra tamento sem deficiēncia hĩdrica na segunda época de plantio para a varie dade Aroana 80 na qual a evapotrasnpiração acumulała no estádio do inicīo 


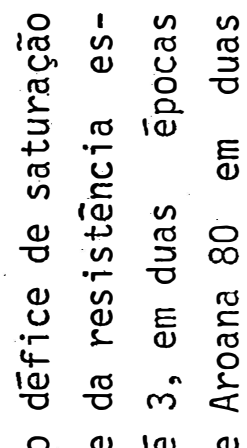

웅 0 용

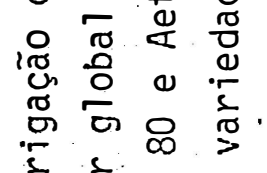

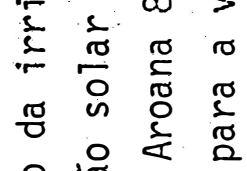

i⿱宀⿻⺀大土

紫告

रे

芒

ช ฮั

융 융

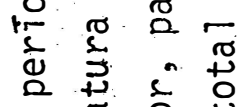

○ s

a \&

茂离

吉 0 i

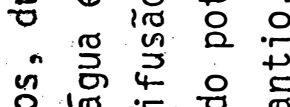

임 0

压 هั

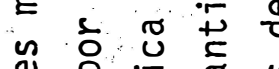

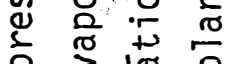

\% ه

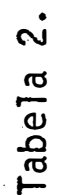

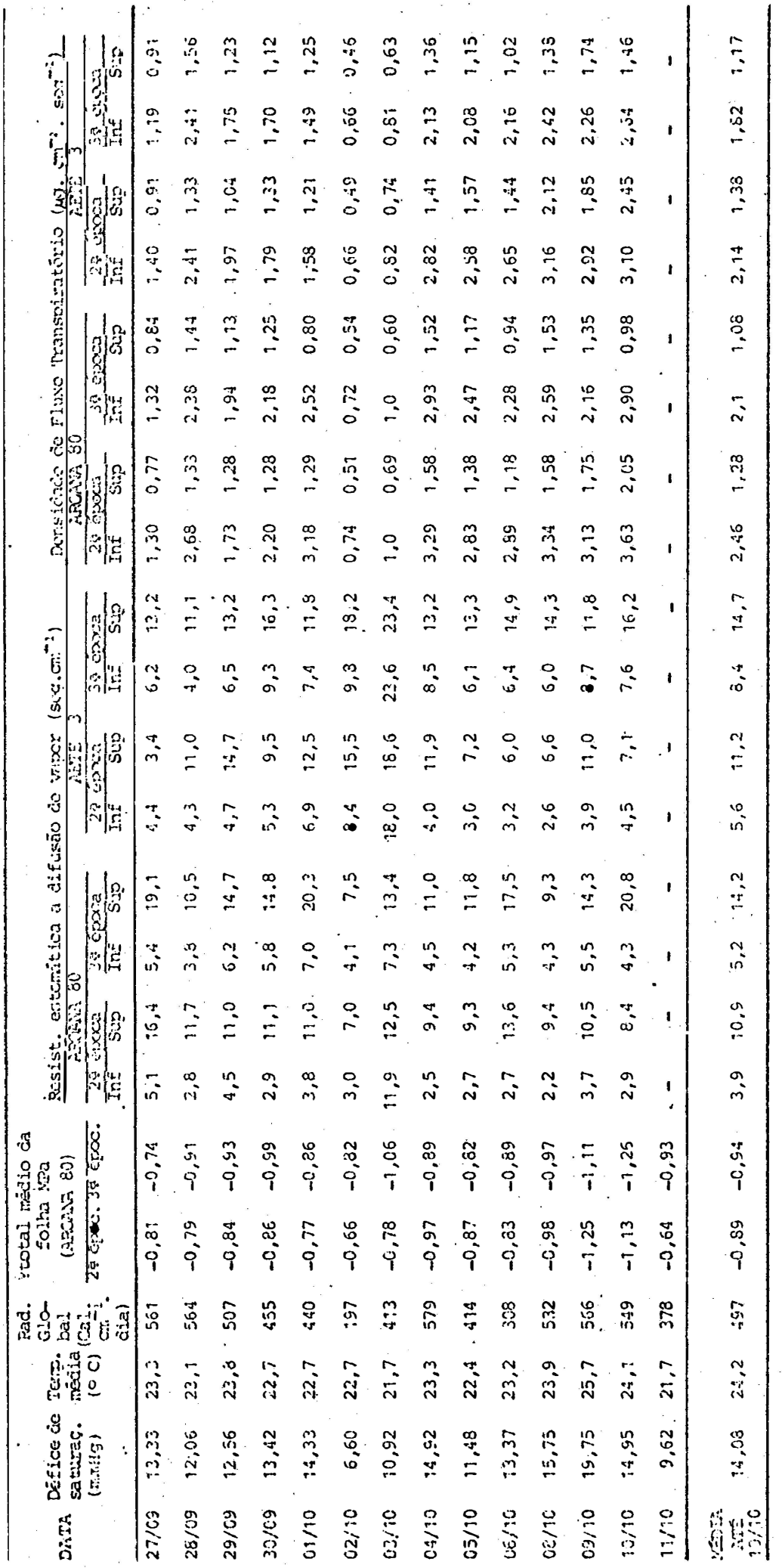


de formação de grãos à maturação fisiológica foi de $203,2 \mathrm{~mm}$ contra $170,4 \mathrm{~mm}$ do estádio anterior considerado. Os valores mīnimos de ETc acumu lada ocorreram dentro do estádio compreendido entre o inĩcio de florescimento ao inîcio de formação de vagens e do inĩcio de formação de vagens ao inīcio de formação de grãos. A evapotranspiração acumulada no ciclo mostrou valores máximos para a variedade Aroana 80 (I) sendo que estes valores foram māximos $(467,2 \mathrm{~mm})$, intermediārios $(345,9 \mathrm{~mm})$ e menores $(341,7 \mathrm{~mm})$ para a segunda, terceira e primeira épocas de plantio, res pectivamerite. Com relação aos valores máximos, atingidos nos tratamentos com défice hîdrico os valores acumulados no ciclo foram de $373,6 \mathrm{~mm}$, $347,0 \mathrm{~mm}$ e $347,0 \mathrm{~mm}$ para a variedade Aroana 80 (I) na segunda e primeira épocas e Aetē 3 (D) na primeira época, respectivamente. Os valores mīnimos atingidos nos tratamentos com défice hîdrico foram de $286,9 \mathrm{~mm}$ e $291,3 \mathrm{~mm}$ e $305,1 \mathrm{~mm}$ para o Aroana 80 (D) e Aeté.3 (D) na terceira ēpoca e no Aetē 3 na primeira época, respectivamente.

- A figura 7 mostra o acúmulo de matéria seca total por unidade de ārea de terreno ao longo do ciclo da cultura para as variedades Aroana 80 e Aeté 3 . Na variedade Aetē 3 não houve diferenças acentuadas entre os valores de matēria seca acumulada atē a ūltima amostragem (anterior à maturação fisiológica completa) nas trēs épocas de plantio, nos tratamentos que não sofreram interrupção do suprimento hỉdrico do solo. Os valores totais nesse caso foram de $280 \mathrm{~g}$ de matéria seca.m $\mathrm{m}^{-2}$ de terreno, $266 \mathrm{~g}$ de matēria seca. $\mathrm{m}^{-2}$ de terreno e $270 \mathrm{~g}$ de matéria seca.m $\mathrm{m}^{-2}$ de terreno, para a primeira, segunda e terceira épocas, respectivamente. 

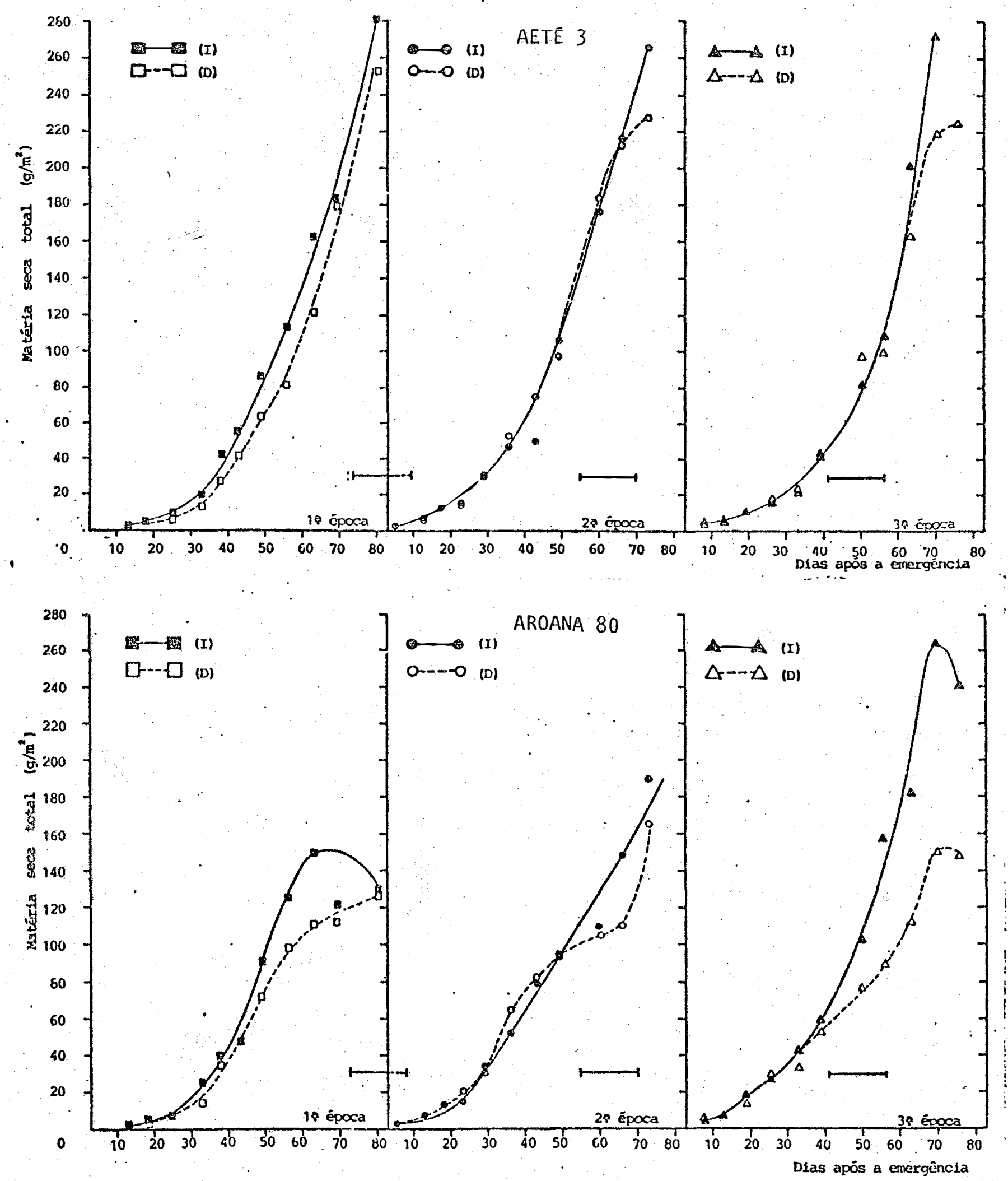

FIG. 7 - Curvas representativas do acümulo de matéria seca para as variedades AETE 3 e AROANA 80 nas três épocas de plantio, com (D) e sern perío do de restrição hídrica (I) no solo. O intervalo ( $\longrightarrow$ ) indica o período de suspensão da irrigação nos tratamentos de irrigação (D) . 
Entretanto, houve diferença na resposta dos tratamentos no que se refere às taxas de acúmulo de matéria seca nos diferentes perĩodos dentro do ciclo de desenvolvimento. Observou-se que atē o 40 ? dia apōs a emergência não houve diferença significativa entre a primeira e terceira épocas de plantio, sendo que a segunda época apresentou um acúmulo maior até este dia. Considerando como uma boa aproximação que as taxas de variação de produção de matēria seca foram constantes em intervalos de dez dias entre o 400 e o 700 dia após a emergência, è possível verificar que entre o 40 e e 500 dia, as culturas apresentaram valores muito próximos para a primeira e segunda épocas de plantio (4,2 e 4,0g de matéria seca $\mathrm{m}^{-2} \cdot$ dia $^{-1}$, respectivamente) e um valor menor na terceira época $\left(3,2 \mathrm{~g}\right.$ de matéria seca $\left.\mathrm{m}^{-2} \cdot \mathrm{dia}^{-1}\right)$, entre o 50 e e o $609 \mathrm{dia}$, os valores foram de $4,2,6,4$ e $5,8 \mathrm{~g}$ de matéria seca $\mathrm{m}^{-2} \cdot \mathrm{dia}^{-1}$, respectivamente para a primeira, segunda e terceira época, valores estes que passa ram a ser de $6,4,6,4$ e $12,3 \mathrm{~g}$ de matéria seca $\mathrm{m}^{-2}$. dia ${ }^{-1}$ para as mesmas respectivas épocas no perīodo entre 60 e 79 dias apōs a emergência.

Para os tratamentos que sofreram um perĩodo de interrupção da irrigação o total de matéria seca acumulada foi semelhante para a segunda e terceira épocas, com a primeira época apresentando um valor de $254 \mathrm{~g}$ de matéria seca $\mathrm{m}^{-2}$ terreno e $225 \mathrm{~g}$ de matéria seca $\mathrm{m}^{-2}$ para as duas épocas restantes. O comportamento do tratamento que sofreu estresse hĩdrico foi semelhante ao do tratamento irrigado até o inīcio do estabelecimento do período de secamento, com exceção da primeira época na qual o tratamento com estresse hídrico apresentou, durante todo o ciclo, valores menores de matéria seca acumulada em relação ao tratamento sem interrupção da irrigação; no entanto os valores de matéria seca 
acumulada neste tratamento e nesta época coincidiram na maior parte do ciclo com os valores da terceira época de plantio. A deficiēncia hídrica afetou a produção de matéria seca mais intensamente na segunda e terceira épocas de plantio, sendo que o efeito da mesma na primeira época não ficou muito caracterizado.

Para a variedade Aroana 80 ocorreram diferenças significativas entre épocas de plantio para o tratamento irrigado, sendo que 0 acúmulo de matéria seca total foi menor, intermediārio e maior para a primeira, segunda e terceira época, respectivamente, com valores de $152 \mathrm{~g}$ matēria seca $\mathrm{m}^{-2}$ terreno, $190 \mathrm{~g}$ matēria seca $\mathrm{m}^{-2}$ terreno e $262 \mathrm{~g}$ matēria seca $\mathrm{m}^{-2}$ terreno, respectivamente. A primeira época apresentou seu valor māximo de matéria seca aos 67 dias apōs a emergēncia, enquanto que a segunda e terceira época aos 74 e 70 dias apōs a emergência, respectivamente, ressaltando-se que para a segunda época a queda da matéria seca total no final do ciclo, provocada pela seneścēncia, não foi caracterizada pela falta de amostragem no final do ciclo.

Atē 0 30 ̣̂ dia apōs a emergência a segunda e terceira épocá tiveram comportamento e valores de acúmulo de mátéria seca semelhantes, apresentando a primeira época durante todo este período valores menores em relação às duas épocas. A partir deste dia, os valores de acūmulo de matéria seca da 1 a época tenderam a aproximar-se dos valores da terceira época atē o dia 550 apōs a emergência, quando então voltaram a . divergir da terceira época, em função do processo de senescência. A segurida ểpoca a partir do 300 dia apōs a emergência adquiriu valores mais baixos de acūmulo de matéria seca em relação às duas outras épocas, 
passando a diferenciar-se das demais, apesar de ter uma ligeira diminuição no acúmulo de matéria seca neste período, ela foi mantida por um tem po maior em relação à primeira época, fazendo com que seus valores de ma téria seca acumulada ultrapassassem os da primeira e mantivessem uma diferença quase constante em relação à terceira época atē o 720 dia.

Considerando-se a aproximação de que os teores de acúmulo de matéria seca em cada época foram constantes a intervalos de dez dias a partir do 40 ̣ dia após a emergência, obteve-se os valores de 5,6, 3,0 e 4,2 g. matéria seca $\mathrm{m}^{-2}$ de terreno. dia-1, respectivamente para a primeira, segunda e terceira épocas de plantio entre o 400 e 509 dias; e $4,6,3,2$ e 6,0 g.matéria seca $\mathrm{m}^{-2}$ de terreno.dia-1 entre o 509 e 609 dia, mantida a sequência anterior de épocas, 3,6 e 10 g.matéria seca $\mathrm{m}^{-2}$ de terreno. dia $^{-1}$ respectivamente para a segunda e terceira épocas entre o 609 e o 700 dia. Atē cerca de 75 dias apōs a emergēncia, a segunda época continuou a apresentar ganho de peso seco quando as delilais já apresentavam diminuição devido a senescência.

Com relação ao tratamento que sofreu o estresse hîdrico nesta mesma variedade, os valores máximos de matéria seca acumulada foram de $127 \mathrm{~g} . m a t e ̄ r i a ~ s e c a . m^{-2}$ de terreno, $165 \mathrm{~g}$. matēria seca.m ${ }^{-2}$ de terreno e $152 \mathrm{~g}$.matēria seca.m $\mathrm{m}^{-2}$ de terreno para a primeira, segunda e terceira épocas de plantio, respectivamente. Neste tratamento notou-se claramente a influência do período de secamento para a segunda e terceira épocas de plantio, sendo maior para a terceira época em relação à segunda. Jā na primeira época esta influência foi atē certo grau confundida com uma diferença que ocorreu desde o início do ciclo entre os 
tratamentos com e sem retirada da irrigação. Na segunda época de plantio houve recuperação de maneira mais intensa do período de estresse do que a terceira época, na qual a influência do período de secamento não causou uma variação tão brusca como na época anterior. Com relação à da ta de máxima matéria seca acumulada não se pode caracterizar com segurança a influência do perīodo de secamento, jā que a ūltima amostragém na primeira e segunda épocas não demonstrou o decréscimo de matéria seca acumulada decorrente da senescência.

Comparando as variedades Aroana 80 e Aetē 3 no tratamento irrigado verificou-se que enquanto a variedade Aetē 3 não respondeu de modo significativo à época de plantio, produzindo na média das trè s épocas em torno de $270 \mathrm{~g}$ de matéria seca. $\mathrm{m}^{-2}$ de terreno, a variedade Aroa na 80 respondeu ao tratamento de épocas e produziu $152 \mathrm{~g}$ de matēria seca $\mathrm{m}^{-2}$ de terreno, $190 \mathrm{~g}$ de matéria seca. $\mathrm{m}^{-2}$ de terreno e $262 \mathrm{~g}$ matéria se$\mathrm{ca} \cdot \mathrm{m}^{-2}$ de terreno na primeira, segunda e terceira épocas de plantio, res pectivamente. Para os tratamentos com interrupção da irrigação o compor tamento foi semelhante ao anterior, modificando porēm os valores māximos, os quais para a variedade Aeté 3 foram em torno de $220 \mathrm{~g}$ de matéria seca. $\mathrm{m}^{-2}$ de terreno para a primeira e segunda épocas e $252 \mathrm{~g}$ de matéria seca. $\mathrm{m}^{-2}$ de terreno para a terceira época; para a variedade Aroana 80 fo ram de $127 ; 165$ e $152 \mathrm{~g}$ de matéria seca. $\mathrm{m}^{-2}$. de terreno pạra a primeira, segunda e terceira épocas de plantio, respectivamente. 
4.2. Relativos ao Perĩodo de Diferenciação dos Tratamentos de Agua no. $\underline{\text { Solo }}$

4.2.1. Valores médios diārios dos parâmetros medidos na planta e na atmosfera

Na tabela 2 e figura 8, são apresentados os valores médios diārios dos diversos parâmetros utilizados para caracterizar as res postas das variedades durante o ciclo de secamento, os valores de défice de saturação de vapor d'água do ar, temperatura do ar e radiação global. A variação māxima destes três parâmetros em torno da média do período es tudado ocorreu para os dias 02,03 e 11/10 com valores minimos e para os dias 08, 09 e 10/10 com valores máximos. Nos demais dias, os valores dos parâmetros utilizados para a caracterização das condições do local apresentaram pequena variação, principalmente no que se refere ao défice de saturação de vapor de água e à temperatura do ar.

0 potencial total da água na folha para a variedade "Aroa na 80" apresentou seus menores valores nos dias 09 e 10/10 e seus maiores valores para os dias $02 / 10$ e $11 / 10$. Excluindo-se a 3 a época para 0 dia $11 / 10$, esses valores extremos 'coincidiram com os extremos dos valores médios de temperatura, dēfice de saturação de vapor de āgua da atmos fera e radiação global. Com relação aos valores de potencial de água na folha, notou-se.que os mesmos mostraram tendência de serem ligeiramente mais negativos para a 3 a época de plantio.

Para ambas as épocas os potenciais totais de āgua na folha permaneceram em termos médios, sem variações bruscas atē prōximo ao dia 

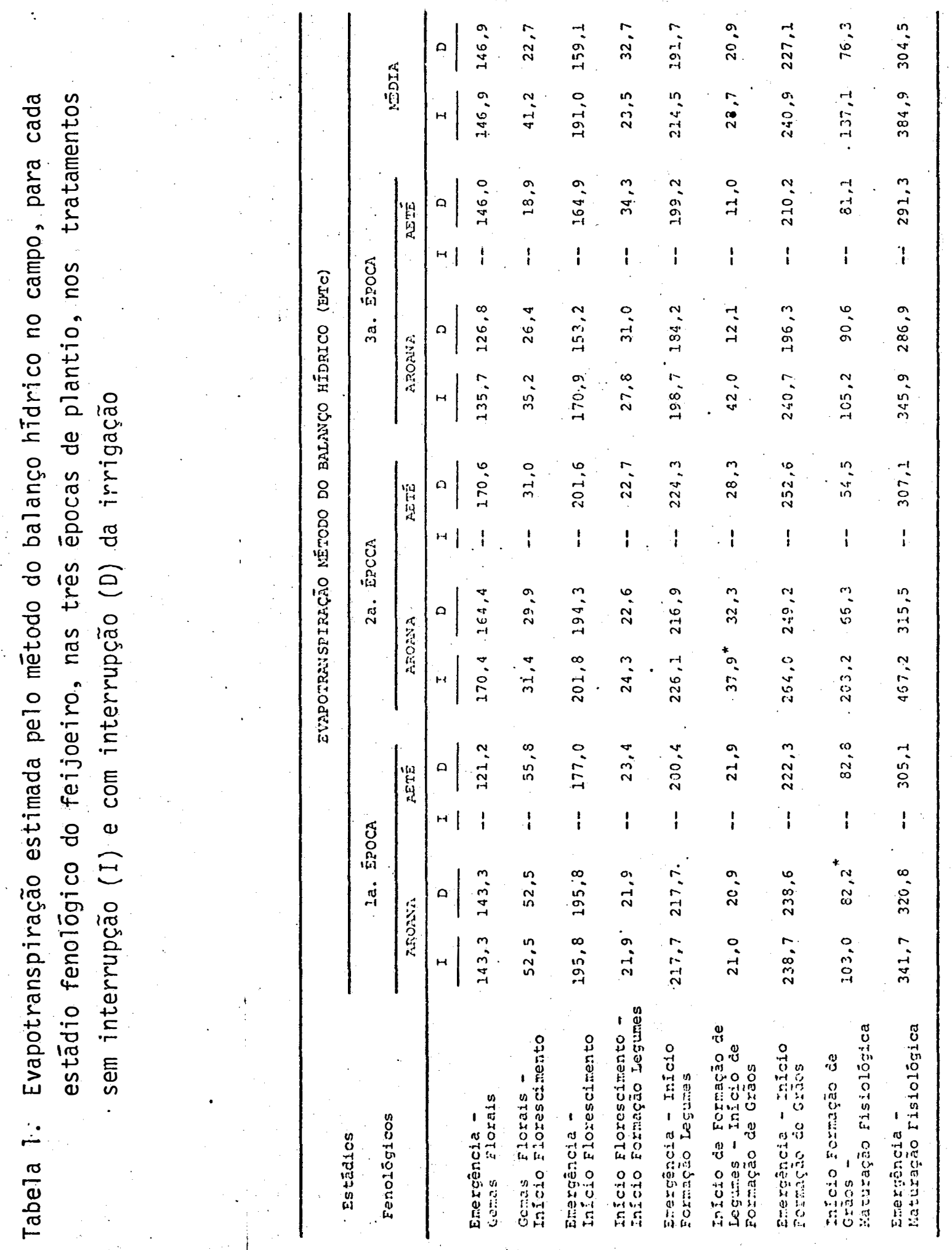


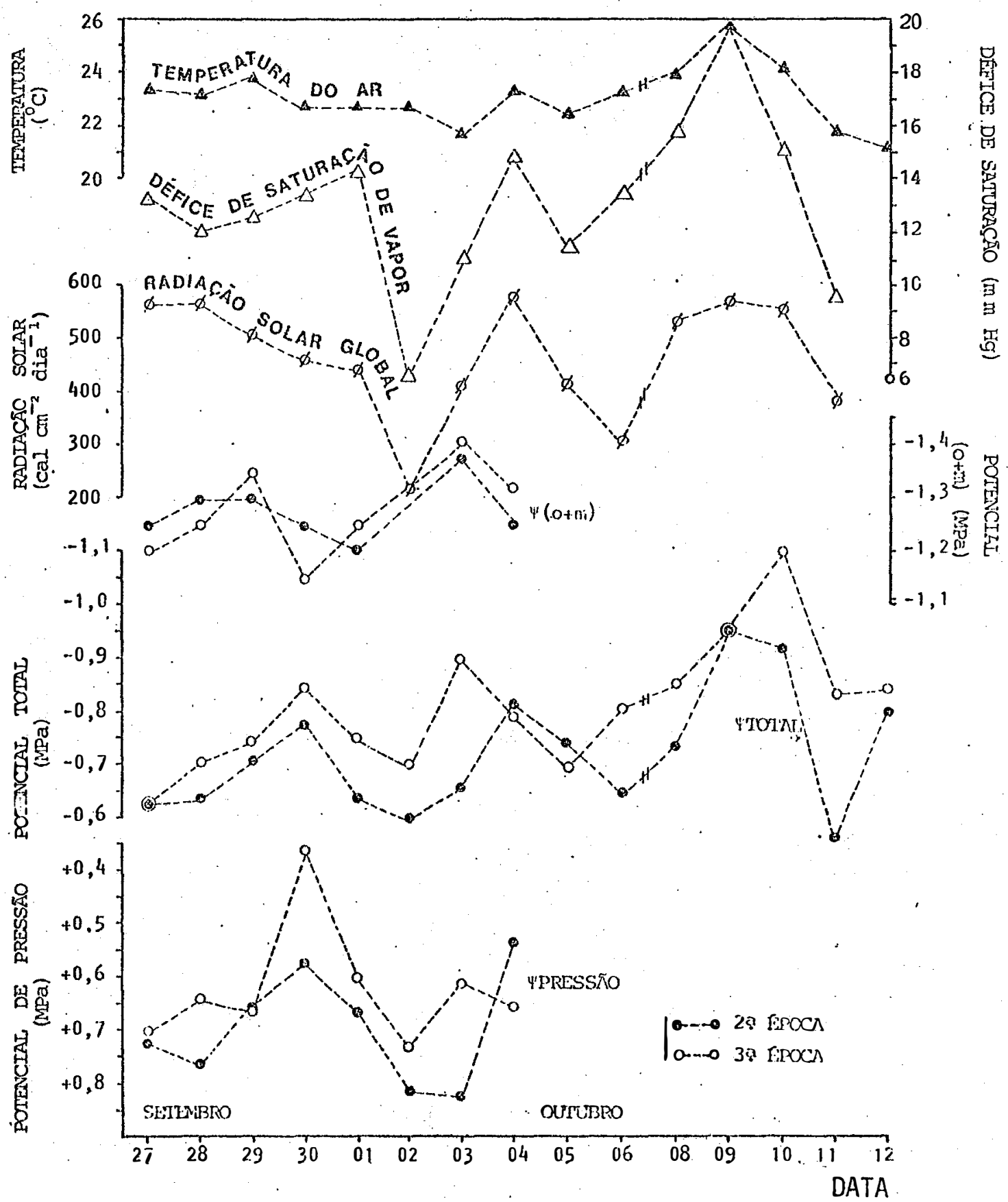

FIG.8. Variação dos valores médios diārio no fotoperīodo,durante o período de secamento do solo do défice de saturação de āgua e da temperatura do ar, da radiação solar global, do potencial total, da soma do potencial osmótico e matricial e do potencial da água na folha na variedade Aroana 80 nas duas épocas de plantio 
08/10, sendo que a partir deste dia a variação foi mais acentuada.

Nas colunas 7 e 8 na figura 9 estão dispostos os valores médios diārios da resistēncia estomātica à difusão de vapor para as duas variedades e duas épocas de plantio. Os valores da resistēncia estomátíca à difusão de vapor durante todo o período foram maiores na face ada xial do que na face abaxial, em ambas as variedades e ambas as épocas de plantio. E a diferença entre as faces apresentaram-se, na maioria dos casos, maiores para a variedade Aroana 80 nas duas ëpocas de plantio. Com relação às épocas, a resistēncia estomātica à difusão de vapor de água na face adaxial da terceira época foi sempre. superior à da segunda época em ambas as variedades, e na variedade "Aroana 80" es ta diferença se apresentou, em média, ligeiramente inferior à da varieda de "Aeté 3". Comparando os valores da resistēncia estomātica à difusão de vapor de āgua, ocorreu sempre uma superioridade da variedade "Aroana 80 " em relação a Aeté 3 , sendo mais pronunciada em relação ã face superior da segunda época de plantio. Considerando ambas as faces das foThas, os valores da resistēncia foram maiores na terceira época. No decorrer do período de secamento a diferença das resistências estomáticas entre as faces das folhas variou aleatoriamente independente do tempo apōs o inīcio do período de secamento, variedade ou época de plantio, e esta variação foi devida principalmente a uma maior variação da resistência estomática da face superior da folha.

Os valores máximos de resistência ocorreram para 0 dia 03/10 onde a temperatura média caracterizou-se como mínima dentro do período. 


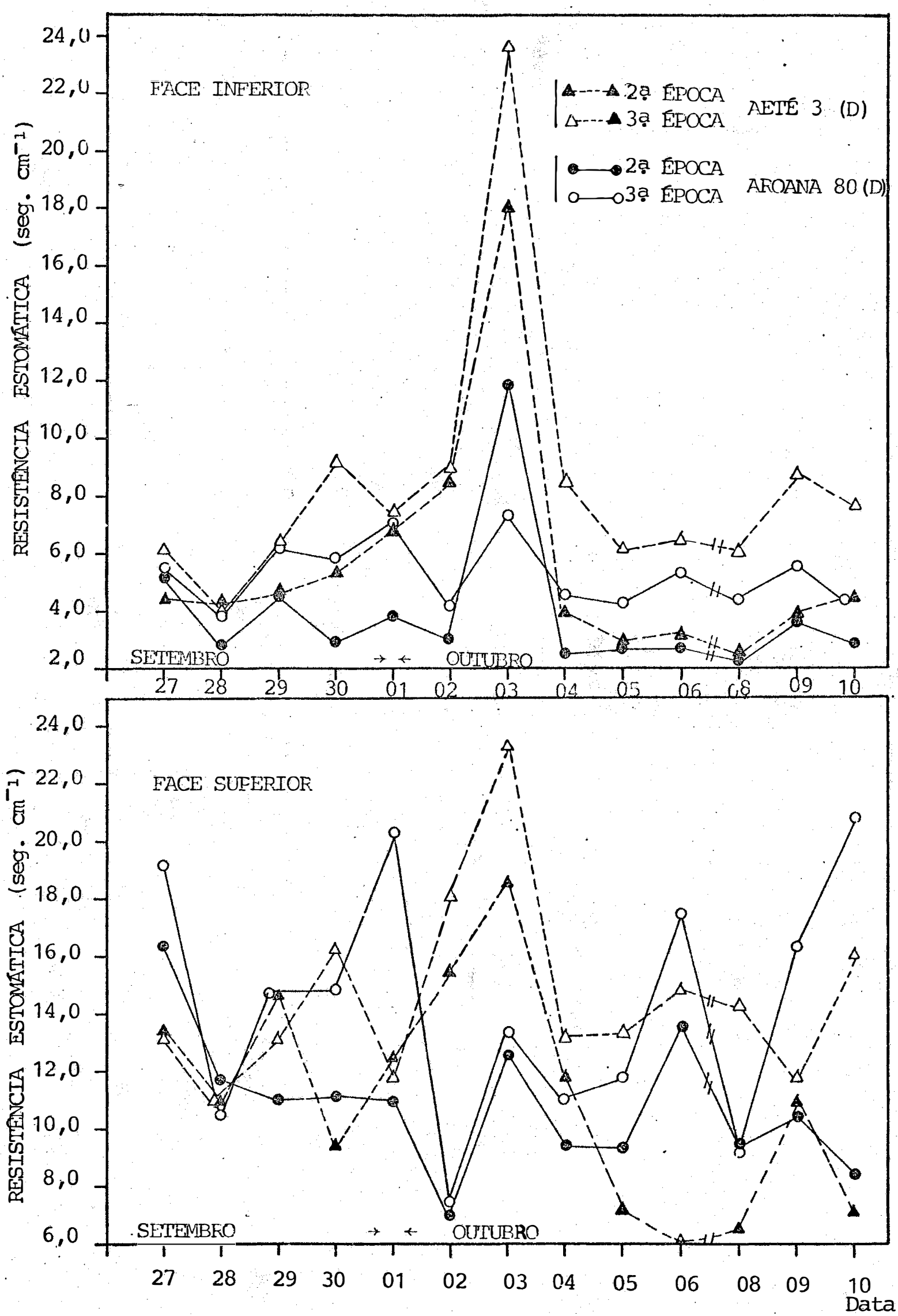


A tabela 2 e a figura 10 trazem a variação dos valores médios diārios da densidade do fluxo transpiratório nas faces abaxial e adaxial para a segunda e terceira épocas deplantio nas variedades "Aroana 80" e "Aeté 3 " durante o período de secamento. Os valores de taxa transpiratōrias para a face abaxial da folha foram sempre inferiores na variedade "Aetē 3" e ligeiramente mais pronunciados na segunda época de plantio em ambas as variedades. Na superfície adaxial a taxa transpiratōria foi superior na variedade "Aroana 80", sendo aproximadamente iguais pará a se gunda e terceira épocas. Em termos médios, as duas variedades apresentaram maiores diferenças entre as duas faces da folha na segunda época de plantio, e em valor absoluto essas diferenças foram quase duas vezes maio res na "Aroana 80 " em relação ao $A$ ao Aeté 3.

$\mathrm{Na}$ tabela 3 são apresentados os valores dos componentes do potencial da àgua para as variedades "Aroana 80" e "Aeté 3" nas duas épocas de plantio no período de 27:09 a 04/10 e no dia 11/10, sendo que o potencial de pressão é apresentado somente para a variedade Aroana 80 . Tais valores são representados na figura 11 .

Com relação aos valores da soma de potenciais osmótico e matricial, notou-se que na variedade "Aroana $80 "$ ocorreu somente um leve acréscimo em termos médios, no decorrer do perīodo estudado, enquanto que na variedade Aeté 3 , houve um significativo acréscimo, iniciando o período com uma diferença da variedade Aroana 80 acima de $-0,3 \mathrm{MPa}$ passando no final a uma diferença de aproximadamente $-0,1 \mathrm{MPa}$ ou menos. Com respeito ao tratamento de épocas não se notaram diferenças significativas, havendo alguma alternância de tendência entre elas no perĩodo. Com 

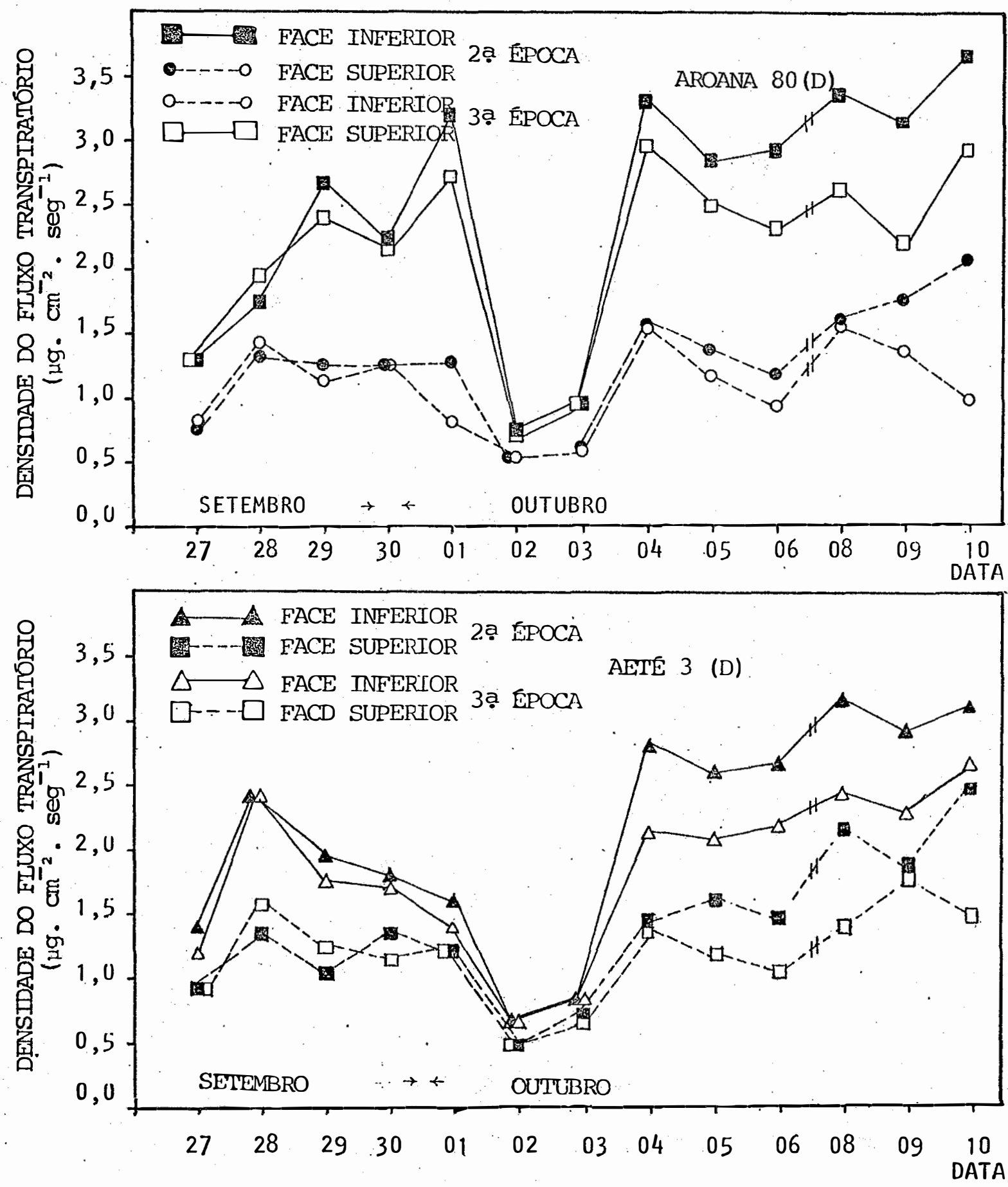

FIG. 10 - Variação da densidade de fluxo transpiratôrio (média horária entre 10:00 às 15:00 horas) durante o período de interrupção da irrigação as duas variedades (A ROANA 80 e AETÉ 3) e duas épocas de plantio. 
respeito aos valores do potencial de pressão, verificou-se uma variação acentuada no decorrer do perĩodo, independente da época de plantio; em termos médios os valores foram maiores para a segunda época em relação à terceira época de plantio.

Os valores da tabela 3 e figura 11 mostram uma diferença de aproximadamente $-0,1 \mathrm{MPa}$ nos valores de potencial osmótico $\left(\psi_{0}\right)$ entre as variedades, a qual é mantida quase constante, sendo que $\psi_{0}$ foi maior para a variedade "Aeté 3". Esta mesma variedade apresentou uma variabilidade bem ampla nos quatro primeiros dias, mantendo-se menos variāvel nos dias restantes; no mesmo período em que houve a maior variabilidade ocorreu também a maior diferença entre épocas com a terceira época apresentando valores mais negativos. Para a variedade Aroana 80 ocorreu tam bém esta mesma variação no início do perĩodo, mas a diferença entre épocas restringiu-se aos primeiros dois dias e com menor intensidade que na variedade Aetē 3 .

Nas duas ūltimas colunas da tabela 3 são apresentados os valores do potencial matricial para a segunda e terceira época de plantio da variedade "Aroana 80", determinados algebricamente pela equação 8. Estes valores não mostram nenhuma tendēncia no perĩodo, nem quanto a uma superioridade de uma época sobre a outra, nem quanto a um decréscimo ou acréscimo dos valores com a sequência de dias. A maior variação. foi encontrada no dia $03 / 10$ onde $0 \psi_{m}$ atingiu os valores máximos de $-0,30$ e $-0,34 \mathrm{MPa}$ para a segunda e terceira épocas de plantio, respectivamente. 


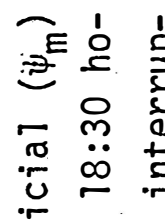

产 थ

E 0 잉

- 음ํㅁ

200

₹ 2

음 음

in 0

ข

莒吕

ه

○

Еั

号

$\geqslant 20$

-

둔 음 등

† a d

茞 的

+ ป ํㅣ

언 으 을

$\because 0$

落

至

n 10

.

‘

ริ

品

쥬

กำ

n 등

$\therefore$ \&

1ॄ

- 5 年

ข

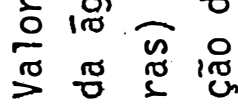

$m$
$\frac{0}{0}$
$\frac{0}{\pi}$

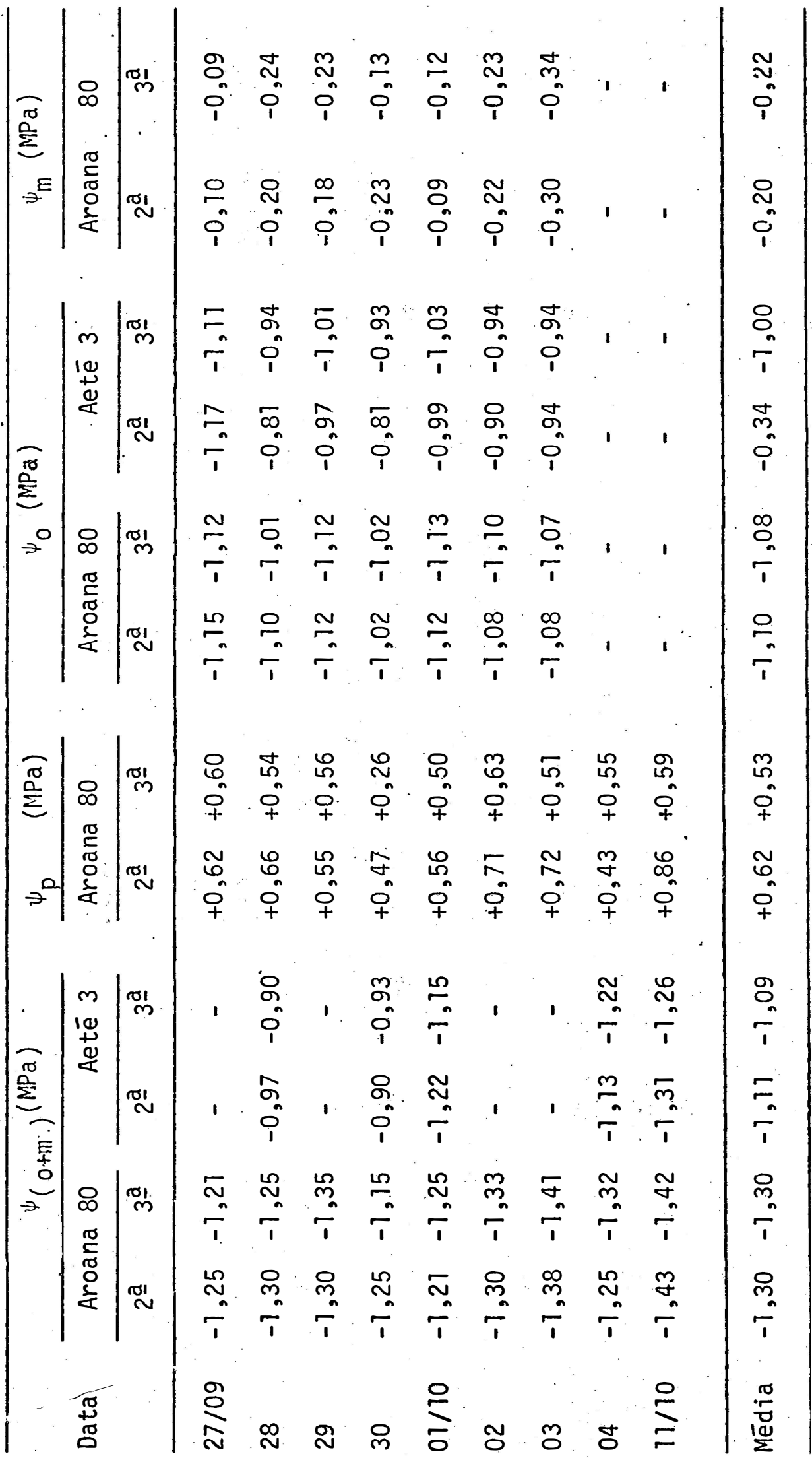



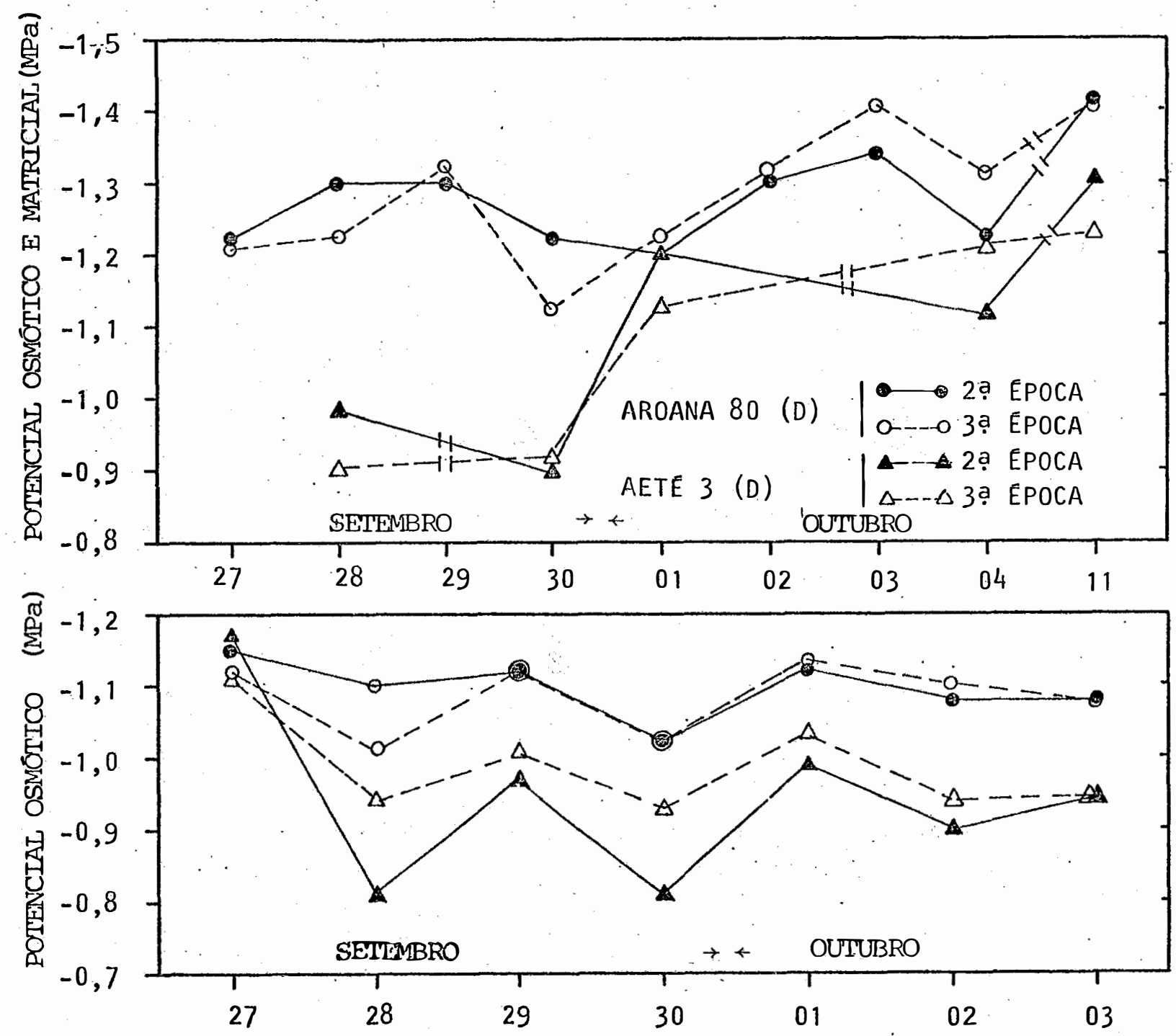

FIG. 11 : Variação dos valores médios horários da soma dos potencias Osmótico Matricial no período compreendido entre $6: 30$ as $17: 30$ horas (a) e do potencial osmótico entre 7:00 às 18:00 horas (b) durante parte do período de seca mento para as duas variedades (AROANA 80 e AETÉ 3) e duass épocas de plantio. 
4.2.2. Variação durante o dia dos parâmetros medidos

As figuras 12 e 13 mostram a variação, durante o perĩodo diurno e no inīcio do período noturno, do potencial total da água na foIha, da taxa de transpiraçāo e da resistēncia estomática à difusão de vapor de āgua na variedade Aroana 80 , bem como do défice de saturação de vapor d'água do ar e da radiação solar global. Devido ao grande número de dados apresentados, foram selecionados vārios dias durante o período de secamento, representativos das variações médias e extremas do perīodo, de modo que a não apresentação dos dados dos demais dias não altera subs tancialmente os resultados e a futura discussão.

0 potencial de água na folha mostrou um padrão de variação caracterīstico em todos estes dias começando com valores máximos em torno das 6:30 horas, os quais variaram entre $-0,25 \mathrm{MPa}$ nos dias $27 / 09$ e 10/10 e valores minnimos de $-0,6 \mathrm{MPa}$ nos dias 04/10 e 11/10, na segunda e na terceira épocas respectivamente. Os menores potenciais ocorreram entre 11:30 e 15:30 horas e, para todos os dias, a maior taxa de recuperação do estado de energia da água da folha ocorreu entre aproximadamente 15:30 e 18:00 horas, tornando-se mais lenta entre 18:00 e 21:00 horas (horário final de medida no dia) e durante o restante do perīodo noturno conforme atestam os valores iniciais de medida no dia subsequente (exemplos nos dias 1, 2, 3 e 4 de outubro). Em vārios casos hā uma elevação do potencial da água em torno das 13:30 horas e uma diminuição em torno das 15:30 horas, que não se mostrou sistemática para ambas as épocas nos dias em que ocorreram. De modo geral os potenciais da àgua foram mais 

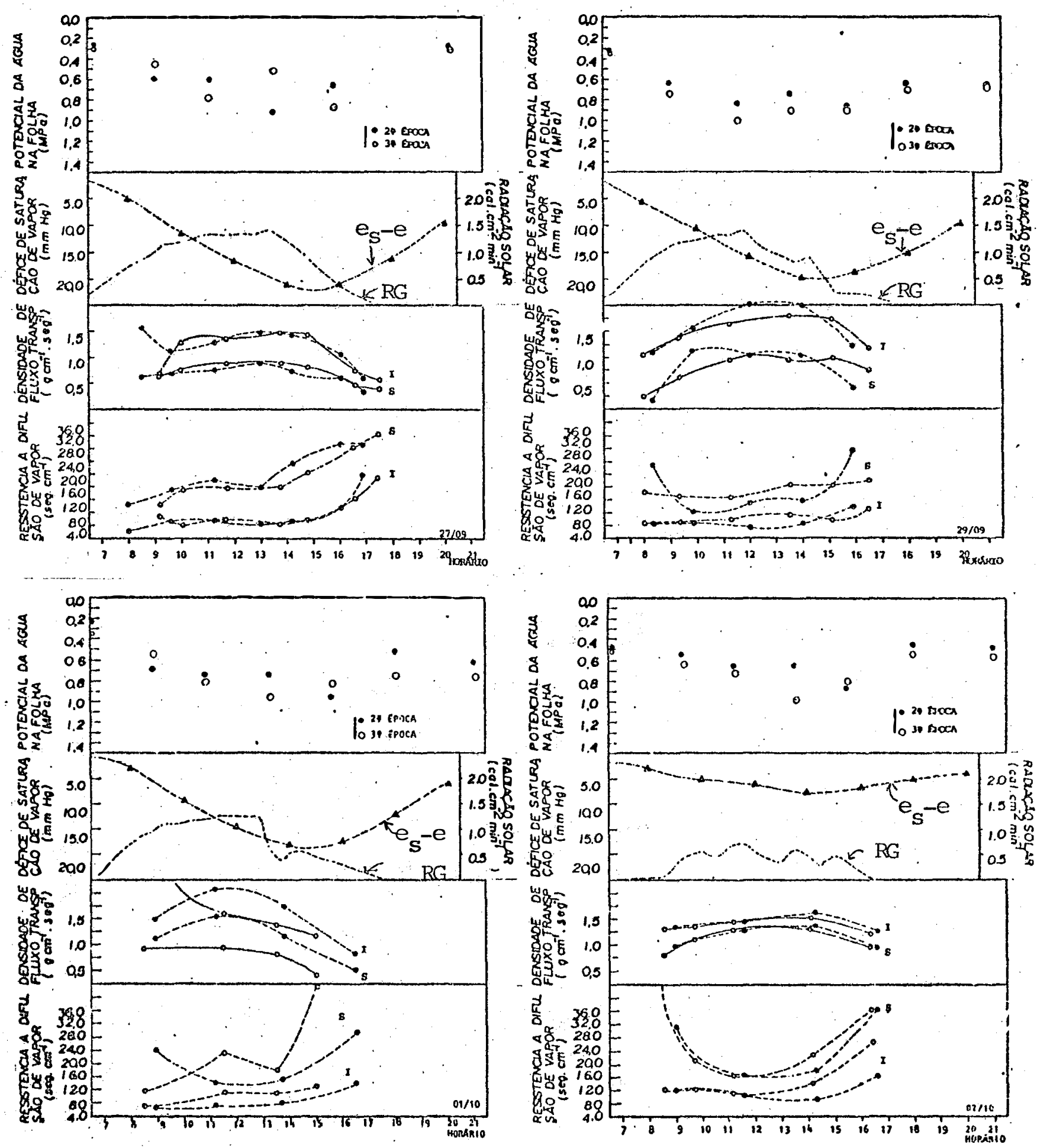

FIG. 12 - Variação do potencial de água na folha, da densidade de fluxo trans piratório, da resistência estomática à difusão de vapor para a variedade AROANA 80 e do défice de saturação e radiação global em vários dias do período de interrupção da irrigação. As letras "I"e"S". indicani a face abaxial e adaxial da folha, respectivamente. 

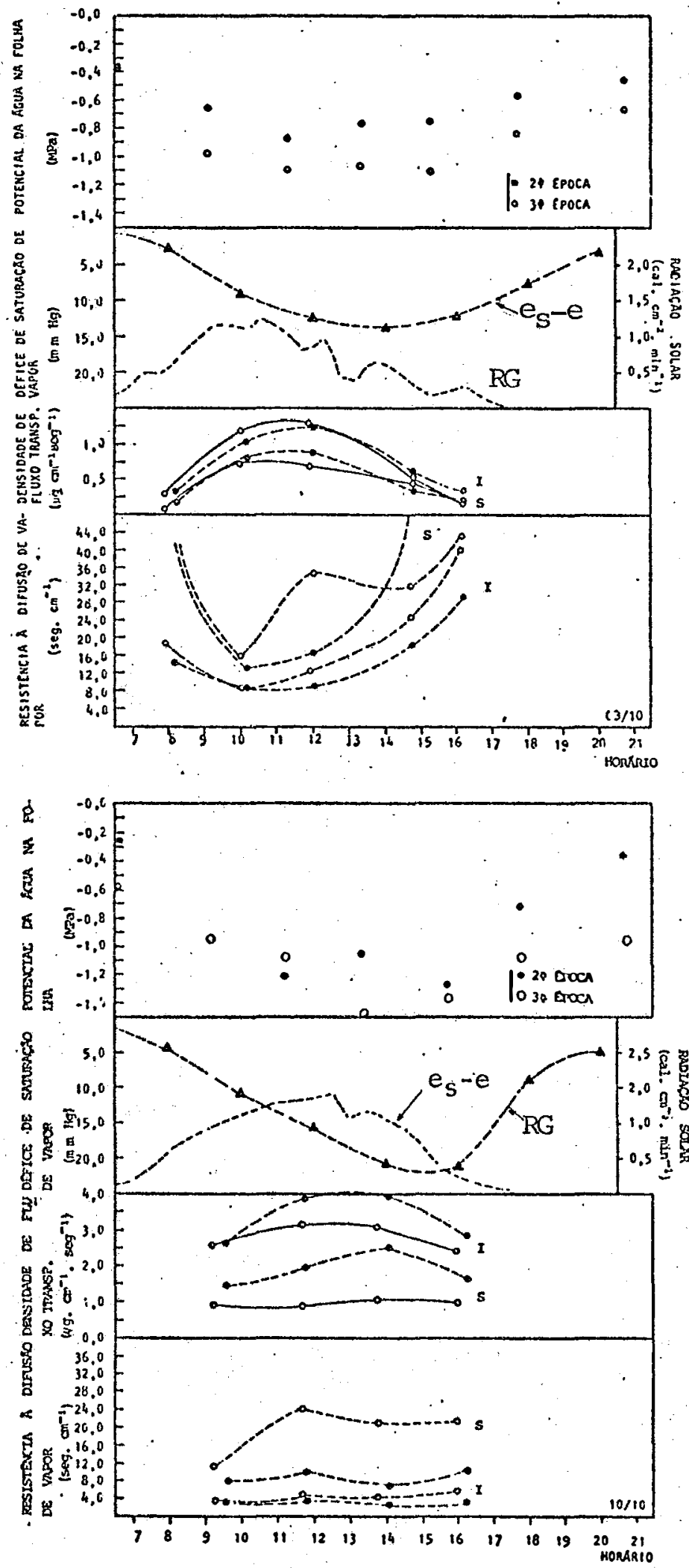
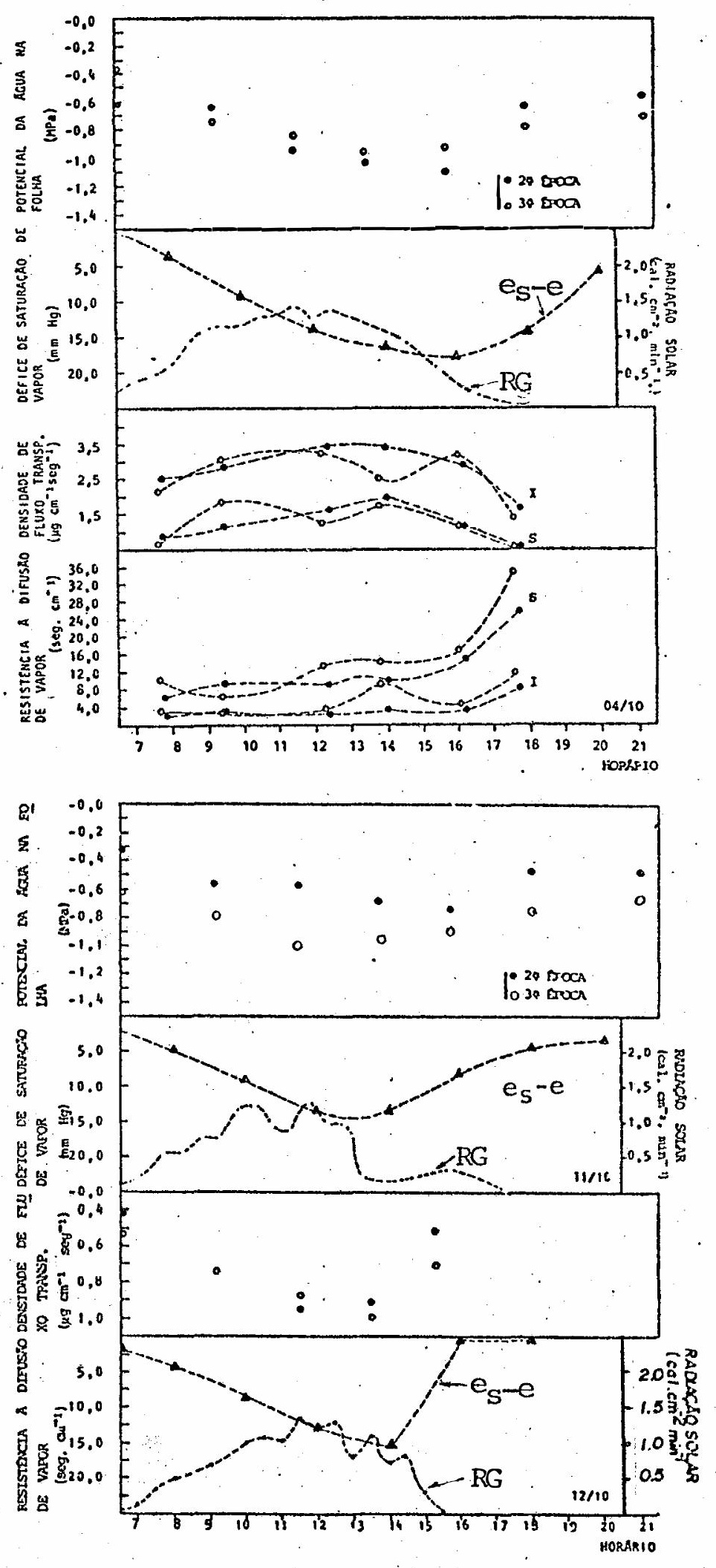

FIG. 13 - variação do potencial de água na folha, da densidade de fluxo transpiratório, da resistência estomática à difusão de vapor para a variedade AROANA80 e do défice de saturação e radiação global em vários dias do período de interrupção da irrigação. 
negativos na terceira época, tendência esta mais acentuada nos dias 10, 11 e $12 / 10$.

A densidade de fluxo transpiratōrio mostrou a tendēncia de aumentar até o meio do dia e início do período vespertino, mostrando uma diminuição a partir de aproximadamente 13:30 horas até o final das medidas, exceção a isso ocorrendo no dia 04/10 para a terceira época de plantio. Na maioria dos dias esse parāmetro mostrou maiores valores para a segunda época de plantio, sendo as maiores diferenças notadas nos dias 27, 29/09, 02 e 03/10, considerando ambas as faces. A maior variação ocorreu no dia 04/10 na terceira época, em ambas as faces, e no dia 29/09 (na face superior) na segunda época. Os maiores valolores ocorreram nos dias 04 e 10/10 onde a densidade de fluxo transpiratōirio na segunda época foi, na maior parte do periodo de medidas, superior à da terceira ēpoca, sendo os valores mínimos determinados no dia 02/10. A face inferior apresentou sempre valores maiores que os da face superior.

Com relação ao comportamento estomātico, verificou-se, com exceção do dia 10/10, uma tendēncia de aumento da resistência à difusão de vapor a partir das 14:00 horas aproximadamente, com valores que variaram pouco entre o início do período de medidas e o meio do dia com exceção da face superior nos dias 01/10 (segunda época) e 02/10 (ambas as épocas) e em ambas as faces e épocas para o dia 03/10. As resistēncias da face superior foram maiores que os da face inferior em todos os dias. Quanto aos tratamentos de épocas de plantio, notou-se que somente para o dia 27/09 os mesmos não diferiram entre as duas épocas, tanto para a 
- face abaxial como na adaxial. Para a resistência de face abaxial notaram-se as maiores diferenças entre as ēpocas, sendo māxima para o dia 10/10, intermediāria para os dias $01 / 10$ e 03/10 e menores para os demais, sendo que os valores foram sempre maiores para a terceira época de plantio. No dia 03/10 foram observados os maiores valores de resistência para esta face entre 10:00 e 15:00 horas. A maior diferença de valores da resistência entre as faces ocorreu para o dia 01, 03 e 10/10 e 27/09 para a terceira época e nos dias 27/09, 03 e 01/10 para a segunda época. Notou-se para os dias 01,02 e 03/10 e levemente para o dia 04/10 que a diferença da resistência dentro de época foi devida ao fato de que o inîcio da elevação dos valores ocorreu na terceira época, antecipadamente ao da segunda época.

O défice de saturação de vapor de āgua no ar apresentou variação muito semelhante no período da manhã e no perĩodo da tarde a té cerca das 15:00 horas nos dias 27, 29/09, 01, 04 e 10/10, com valores mäximos entre $18,0 \mathrm{mmHg}(04 / 10)$ e $22,0 \mathrm{mmHg}(27 / 09$ e 10/10). Esta variação pode ser considerada também como semelhante no periodo compreendido entre às 15:00 e às 20:00 horas mantendo-se as diferenças mäximas de 4,0mm encontradas quando do estabelecimento do valor máximo do défice às 15:00 horas, com exceção do dia 10/10, em que a recuperação de $e_{s}-e_{a}$ foi rápido, passando de 22,0mmHg para 8,5mmH jā às 18:00 horas. Nesses dias ocorre ram os maiores valores de radiação global no período, com as māximas de

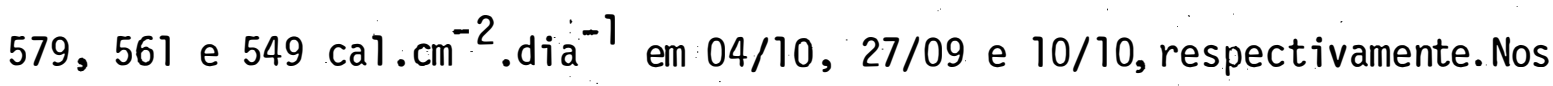
dias 29/09, 01/10 ocorreu nebulosidade mais intensa no período da tarde que ocasionou uma diminuição nos valores de radiação global nessas datás 
29/09 e 01/10 (507 e $440 \mathrm{cal}^{\mathrm{cm}} \mathrm{cm}^{-1} \cdot \mathrm{dia}^{-1}$, respectivamente), mas de modo geral pode-se concluir que os cinco dias citados são comparāveis quanto às condições de radiação global e de défice de saturação de vapor de àgua do ar.

Os dias $02 / 10,03 / 10$ e $11 / 10$ foram particularmente diferentes quanto a radiação solar global e ao défice de saturação de vapor d'água do ar em relação aos cinco dias anteriormente citados. 0 dia 02/10 mostrou pequena variação do défice de saturação de vapor, atingindo um valor máximo de $8,0 \mathrm{mmHg}$, sendo um dia com baixo valor de radiação global (197 cal. $\mathrm{cm}^{-2} \cdot \mathrm{dia}^{-1}$ ) com oscilações desta ūltima indicando um dia nublado. Esse ūittimo fato também foi observado nos dias 03 e $11 / 10$, com as diferenças de que estes dias apresentaram uma variação maior do défice de saturação, atingindo 14,0 e $15,5 \mathrm{mmHg}$, respectivamente, mas com 1 igeira diferença entre ambos os dias quanto ao horário em que esses valores foram atingidos e à variação posterior a estes, pois no dia $11 / 10$ a recuperação do défice de saturação ocorreu numa taxa maior atē às 19:00 horas como consequência da diminuição da radiação global observada nesse dia para tal perīodo.

Em termos, de anālise, podem-se considerar três grupos de dias durante o período de secamento do solo, com características idênticas de elementos meteorológicos observados dentro de cada grupo: um com alta nebulosidade, baixo défice de saturação de vapor e de radiação global $(02 / 10)$; outro com valores intermediários desses valores (03 e 11/10); e um terceiro combreendendo os demais dias, com valores máximos desses parâmetros. Os dados de 1 e 12/10 foram apresentados apenas para 
caracterizar os dias finais de medida no período de secamento do solo, jā que não foram realizadas medidas de transpiração e de resistēncia estomática, tendo havido inî́cio de precipitação pluvial no dia 12/10 a par tir das 15:00 horas.

\subsubsection{Variação dos parâmetros relacionados ao fluxo hỉdrico e às condições meteorológicas no fotoperíodo e inīcio do perīodo noturno}

\subsubsection{Na variedade "Aroana 80"}

As figuras 14 e 15 mostram para as mesmas datas referidas no item 4.2.1, as variações no período diurno e parte do noturno do potencial total $\left(\psi_{t}\right)$ e de seus componentes, potencial osmótico $\left(\psi_{0}\right)$ e potencial de pressão $\left(\psi_{p}\right)$, bem como a soma dos potenciais osmótico e matricial $\left(\psi_{0+m}\right)$ da āgua na folha, para a variedade "Aroana $80 "$ na segunda e terceira época de plantio. 0 potencial osmótico é mostrado somente para os dias 29/09, 01/10,02/10 e 03/10, devido aos mọtivos citados em Materiais e Métodos, sendo sua representação grä́fica, para o dia 27/09 mostrada na figura 16.

Tanto o potencial osmótico quanto a soma deste com 0 potencial matricial acompanharam a tendência de variação diāria do potencial total, com valores máximos no início e no final do período de medidas e mînimos ao redor do meio dia, sendo porém que a amplitude de varia ção foì menor quando comparada à de $\psi_{t}$, os valores de $\psi_{(0+m)}$ mostraram tendēncia de terem menor amplitude de variação em relaçã்o aos de $\psi_{t}$, porém amplitude maior em relação aos de $\psi_{0}$. 

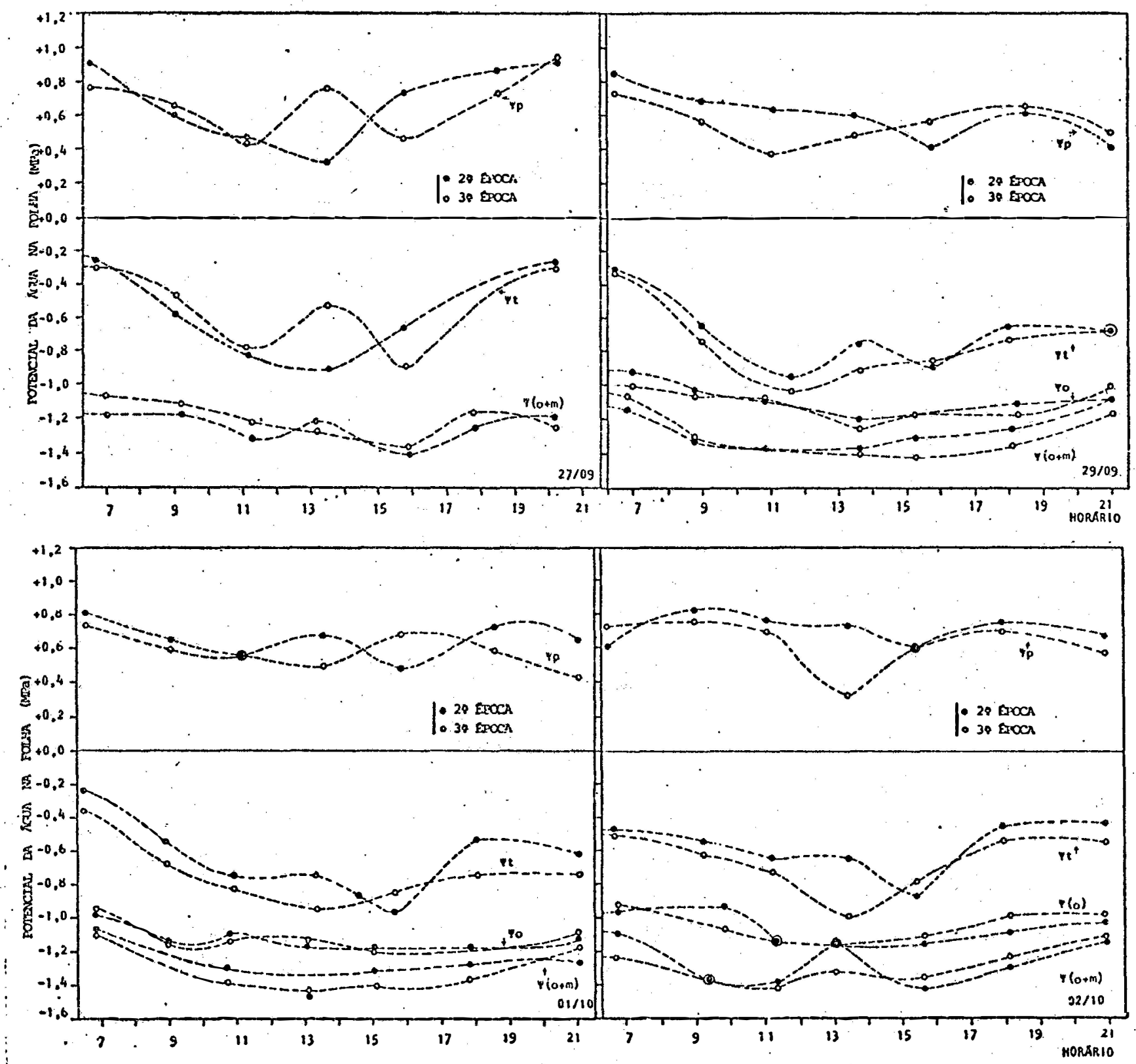

FIG. 14 - Variação durante o periodo diurno e parte do noturno, do potencial total da àgua na folha $(\psi t)$ de seus componentes, potencial osmótico $\left(\psi_{0}\right)$ potencial de pressão $(\psi p)$ e da soma dos potenciais osmōtico e matricial $\left(\psi_{0}+m\right)$ da variedade Aroana 80 para os tratamentos de interrupção da irrigação 

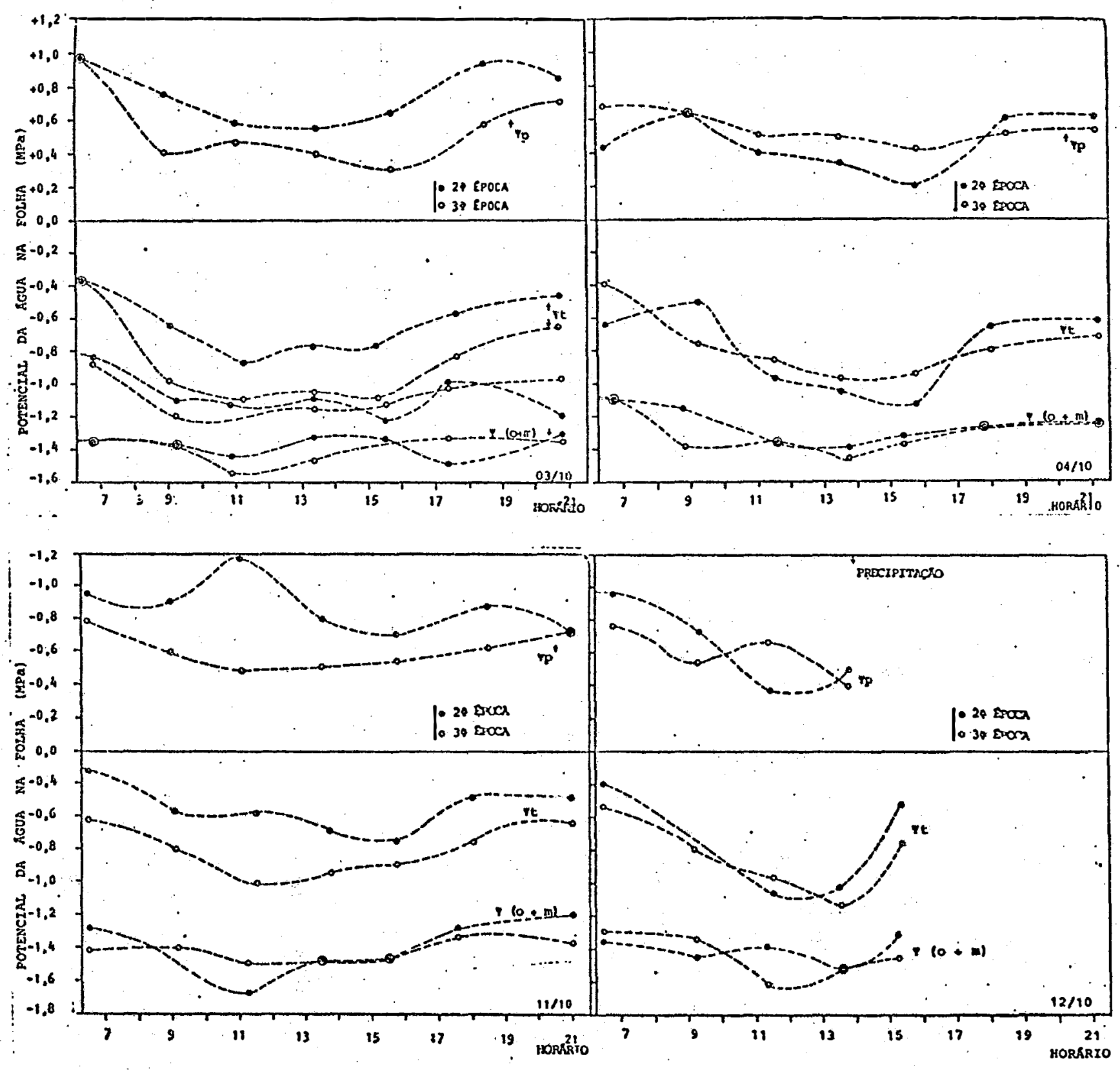

FIG. 15 - Variação durante o perïodo diurno e parte do noturno, do potencial total da àgua na folha ( $\Psi t$ ) de seus componentes, potencial osmótico ( $\psi$ o) potencial de pressão ( $\Psi p$ ) e da soma dos potenciais osmótico e matricial $\left(\psi_{0}+m\right)$ da variedade Aroana 80 para os tratamentos de interrupção da irrigação 
0 potencial de pressão mosirou para a maioria dos dias uma tendēncia de recuperação no final da tarde, sendo que às 21:00 horas apresentou valores jā próximos do inīcio do período matinal nos dias 27/09, 02/10,03/10,04/10 e 11/10, enquanto que nos dias 29/09 e 01/10, a variação de seus valores foi relativamente pequena e para as 21:00 horas mostraram tendēncia de diminuirem em relação às medidas anteriores do dia, embora essa possa ser apenas uma tendência aparente, pois os erros envolvidos na determinação de $\psi_{p}$ podem ser de magnitude idēntica à prōpria variação dos valores no dia.

Dentro de cada dia geralmente é difícil verificar uma pre dominância dos valores dos componentes do potencial total da água de uma época em relação à outra, com exceção dos dias 03 e $71 / 10$, em que os potenciais de pressão da āgua na segunda época foram superiores aos da ter ceira o dia todo, e no dia $04 / 10$ em que os da terceira época sobrepujaram os da segunda época atē o inî́cio da noite. Entretanto, durante o perīodo de recuperação do potencial da āgua a partir do final da tarde, o potencial de pressão na segunda época tende em todos os dias, com exceção do dia 29/09, a aumentar mais rapidamente do que na terceira época de plantio. Para o período matinal e início do período da tarde sempre houve uma tendēncia do potencial de pressão na terceira época ser in ferior ao da segunda época de plantio em todos os dias, com exceção do dia $04 / 10$ e no dia $27 / 09$ no qual a variação do potencial total e do potencial de pressão apresentaram um aumento brusco às 13:30 horas na terceira época de plantio, que pode ter sido causado por problemas de variabilidade espacial e de amostragem no campo. 


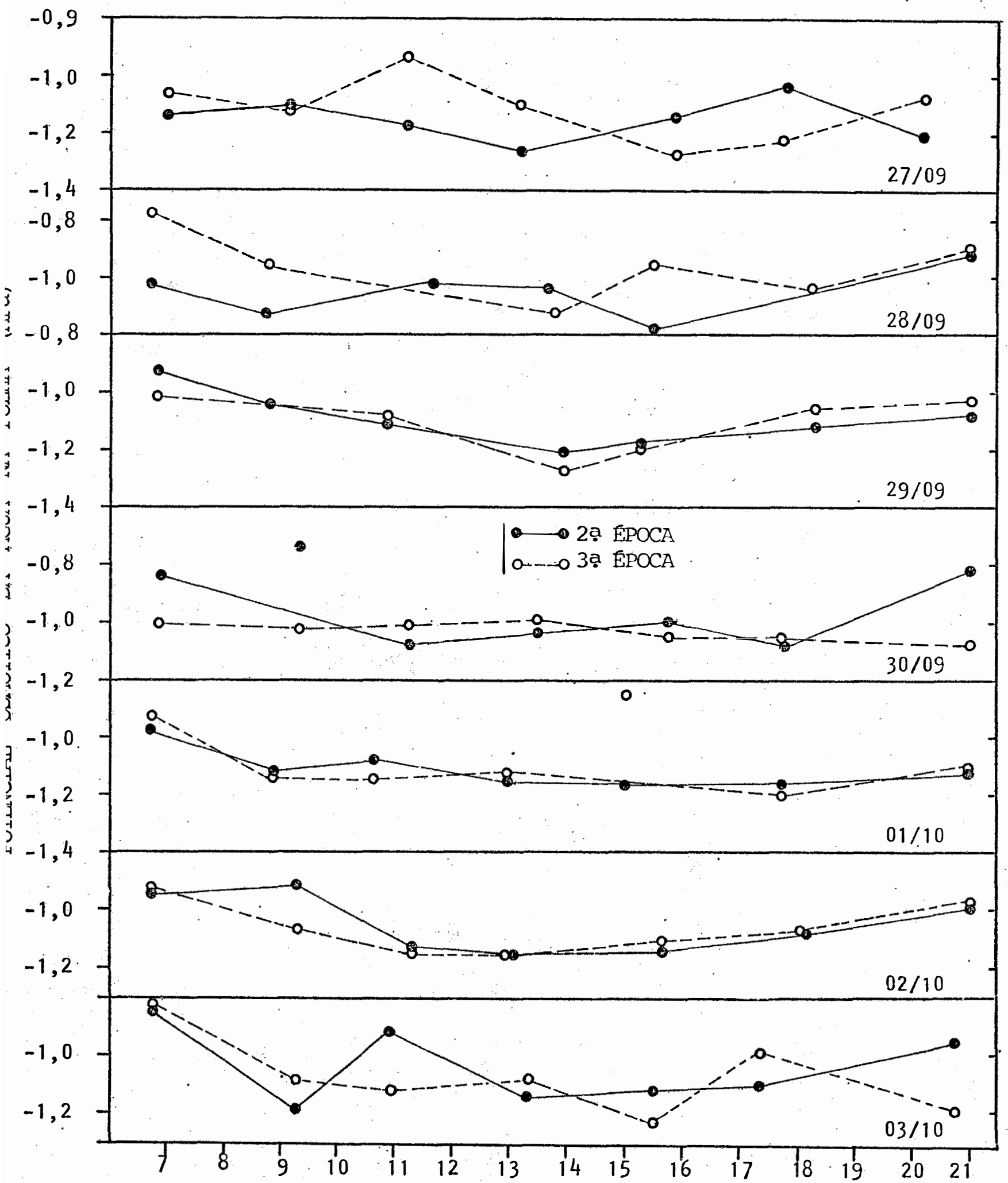

FIG. 16: Variação dos valores de potencial osmótico da áqua na folha nORÁRlo no fotoperiodo e primeiras horas notumas na variedade AROANA 80 em duas épocas de plantio, na épora e para os tratamentos de interrupção de irrigação. 
Para maior detalhamento das variações de $\psi_{0}$ na variedade Aroana 80 a figura 16 mostra seus valores para os dias no período .. de $27 / 09$ à $03 / 10$. Os dados indicam que a tendência do comportamento encontrada é comparāvel àquela encontrada em espécies estudadas por outros au tores, onde o potencial mais elevado è atingido nas primeiras horas da manhã e o minnimo no inīcio da tarde e com posterior recuperação durante o perĩodo noturno. Não foi notada nenhuma diferença significativa e constante em qualquer hora do dia e primeiras horas noturnas, em função da época de plantio. Para o dia $27,28 / 09$ e $03 / 10$ os valores de $\psi_{0}$ apresentaram uma alternância mais acentuada do que os demais dias e os valores mais baixos e mais altos ora estão na segunda época, ora na terceira ēpoca, não apresentando tendência définida. Para os dias restantes os valores dos potenciais são bastante semelhantes para as duas épocas. A maior amplitude de variação ocorreu em termos médios, para 0 dia 29/09 e a menor amplitude ocorreu, em termos médios, para 0 dia $30 / 09$.

Em linhas gerais pode-se dizer que as diferenças entre as duas épocas quanto ao potencial total na folha tiveram uma contribuição maior do potencial de pressão, embora se ressalve que nas determinações de $\psi_{p}$ incorram os maiores erros em relação aos demais potenciais medidos pelo fato de $\psi_{\mathrm{p}}$ ser determinado algebricamente depois de conhecidos os potenciais totais e a soma dos potenciais osmótico e matricial.

Observou-se que o potencial da água na folha raramente ultrapassou o valor mínimo de $-1,0 \mathrm{MPa}$, com exceção no dia 03/10 para a terceira época e 04/10 na segunda época de plantio, bem como no dia 10/10 
no qual as duas épocas apresentaram valores inferiores a $-1,0 \mathrm{MPa}$ em boa parte do fotoperíodo.

Em termos de estado de energia da āgua na folha, observou-se pelos dados que, em geral; as plantas da terceira época de plantio estiveram submetidas a um défice hídrico maior, sendo em alguns dias por um período mais prolongado do que os da segunda época.

\subsubsection{Na variedade Aetē 3}

A figura 17 mostra a variação do $\psi_{0}$ da variedade "Aetē 3" ao longo do perīodo luminoso e primeiras horas noturnas entre 27/09 e 03/10. Em termos médios, apesar da pequena diferença em termos absolutos, a tendência é um maior valor de potencial na primeira determinação da manhã, um gradual decréscimo até atingir valores mĩnimos no inî́cio da tarde, para então começar a recuperação. Esta recuperação não ocorreu totalmente atē prōximo às 21:00 horas somente para o dia 27/09 e para os dias 01/10 e 02/10 para a terceira época e dia 28/09 para a segunda época. Apesar de uma certa oscilação durante o período luminosó, notou-se uma tendēncia da segunda época ter um $\Psi_{0}$ maior em relação à terceira épo ca de plantio. A diferença mais constante durante o decorrer do dia deu se em 27/09 e em 02/10, com a maior e a menor diferença, respectivamente. A variação de $\psi_{0}$ mostra uma tendéncia de ser maior no perīodo de desenvolvimento do estresse hîdrico do que para as horas de recuperação. A maior amplitude de variação para a terceira época ocorreu no dia 27/09 e a menor no dia 02/10. Para a segunda época a maior amplitude de variação ocorreu no dia 01/10 e a menor no dia 02/10, coincidindo com 0 


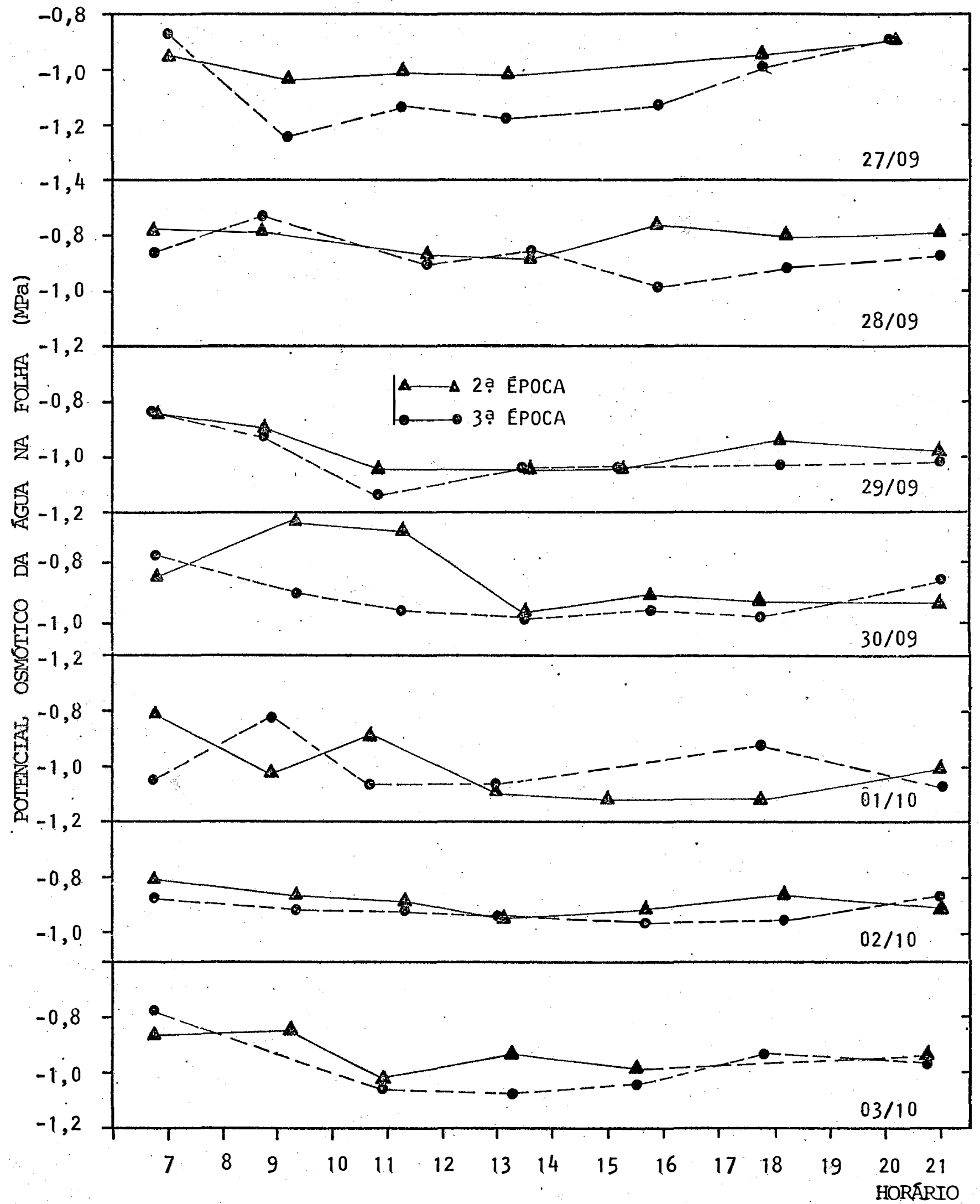

FIG. 17 - Variação dos valores do potencial osmótico da água na folha no fotoperiodo e primeiras horas noturnas na variedade AEIE 3 em duas épocas de plantio, durante e para os tratamentos de interrupção da irrigação. 
dia de menor amplitude da terceira época.

Na figura 18 são mostradas as variações da densidade de fluxo transpiratório e a resistência à difusão de vapor de āgua na variedade Aeté 3 nas duas épocas de plantio para os tratamentos com deficiência hĩdrica.

A transpiração mostrou a tendência de apresentar-se com valores mínimos no inîcio do período de medidas, máximo por volta do meio do dia e valores mínimos novamente no final do perīodo. A maior va riabilidade, maior diferença entre faces das folhas para uma mesma época ocorreram nos dias 28/09, 04/10 e 10/10, sendo que a maior diferença ocorreu para a segunda época de plantio. Os dias 02/10, 03/10 e 01/10 foram os dias que apresentaram a menor variabilidade e a menor diferença entre épocas e.entre faces, sendo menor, intermediāria e maior respectivamente para os referidos dias para as diferenças entre faces. Para os dias de menor variabilidade dos valores e para o dia 04/10 as diferenças entre faces e entre épocas quando existentes permaneceram com valores relativamente constantes durante o perīodo. Nos demais dias esta situação foi alterada por uma variação mais brusca dos valores ae uma das faces.

A densidade de fluxo transpiratório nos dias apresentados foram sempre maiores para a face inferior excluindo-se o dia 03/10 no qual, por volta das 15:30 horas, houve uma inversão desta situação. Os dias em que os valores se apresentaram com menor variabilidade foram aqueles de menores valores de densidade de fluxo transpiratório para ambas as faces. 

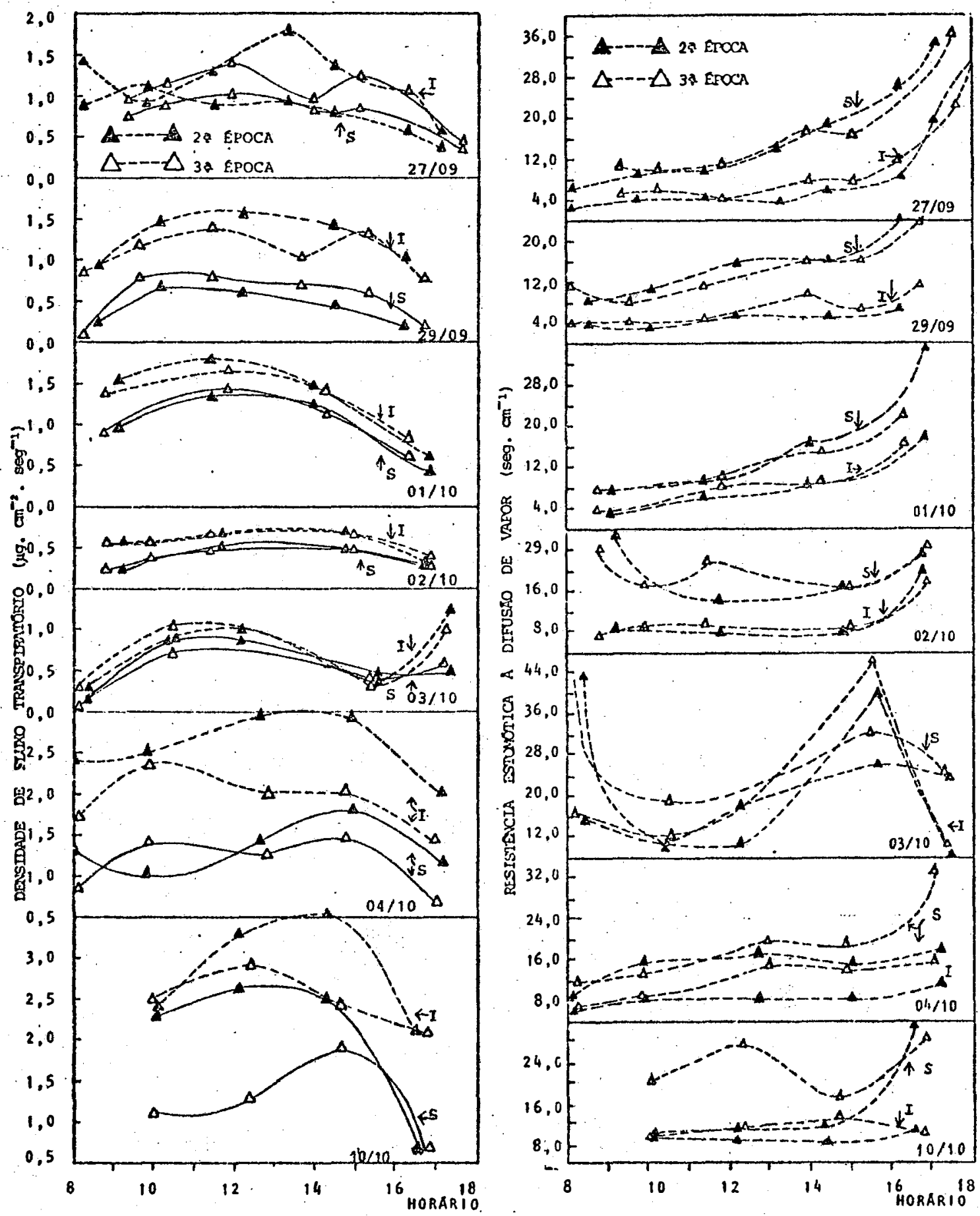

FIG. 18 - Variação da densidade de fluxo transpiratório e da resistên cia estomática à difusão de vapor de água na variedade AEI 3 em duas épocas de plantio para os tratamentos com interru pção da irrigação. As letras "I" e "S" indicam a facē abaxial e adaxial da folha, respecitvamente. 
Para o dia $27 / 08,02 / 10$ e $03 / 10$ não se notou uma diferença entre épocas tanto na face inferior como na superior. Nos dias 29/09 e 01/10 notou-se, uma pequena diferença no comportamento das épocas sendo que a densidade do fluxo transpiratōrio na terceira época da face inferior foi maior em relação à da segunda época e em relação à face superior a densidade de fluxo foi maior para a segunda época.

Para os dias 04/10 e 10/10 ocorreram as maiores diferenças entre as faces e entre as épocas.

A resistência estomātica à difusão de vapor seguiu o comportamento normal à cultura do feijoeiro, ou seja, com valores mais ou menos constantes entre as 10:00 e 15:00 horas, salvo para o dia 02/10, 03/10 e 10/10 onde os valores apresentaram uma certa variabilidade, prị cipalmente para a terceira época de plantio. As diferenças entre as faces dentro de cada época foram maiores no dia 10/10 para a terc?ira época, onde jā às 10:00 horas apresentaram-se altas.

Em termos de valores médios a resistência da face abaxial permaneceu na faixa de $3-10 \mathrm{seg} \cdot \mathrm{cm}^{-1}$, salvo para 0 dia $03 / 10$, onde estes valores apresentaram-se como os mais altos dentre todos os dias para o período compreendido entre as 10:00 e 15:00 horas, sendo da ordem de aproximadamente $44,0 \mathrm{seg} . \mathrm{cm}^{-1}$ às $15: 00$ horas. Para a face adaxial 0 comportamento foi semelhante, sendo que prōximo das 15:00 horas, os valores médios não ultrapassaram o valor de $18 \mathrm{seg} . \mathrm{cm}^{-1}$ excetuando-se 0 dia $03 / 10$, onde os valores atingidos foram de aproximadamente $29 \mathrm{seg} . \mathrm{cm}^{-1}$ naquele horário. Com relação ao acréscimo dos valores no final da tarde notou-se que ocorreu primeiro na face adaxial e posteriormente na face 
abaxial. Com relação a valores relativos pode-se dizer que este aumento na parte final da tarde ocorreu para os dias $27 / 09,01 / 10,03 / 10$ com uma certa antecedência quando comparado com os demais dias.

Em linhas gerais pode-se considerar como característicos os dias 03/10, por apresentarem valores superiores aos demais por volta das 15:00 hioras e uma inversão de valores com referência a faces no mesmo horário. E o dia 10/10 pelo fato de que da terceira época apresentou valores superiores de resistência estomática à difusão de vapor em relação aos da segunda época.

\subsubsection{Comparação das duas variedades}

Na figura 19 são apresentados os valores médios de potencial osmōtico da segunda e terceira épocasde plantio em cada horārio de medida para as duas variedades estudadas. "Ao utilizar valores médios normalizaram-se osdados e a variabilidade dentro de cada período foi diminuîda. Esta diminuição de variabilidade no período para cada variedade possibilitou visualizar uma diferença razoável e constante entre elas, exceção a alguns valores que introduzem variações bruscas nā curva . representativa das respostas das plantas com respeito ao $\psi_{0}$, como nos dias 27, 29/09, 01 e 03/10 às 11:15, 10:20, 15:00 e 10:50 horas, respectivamente. A variedade Aetē 3 apresentou valores superiores aos da variedade Aroana 80, salvo nos horários acima referidos. As maiores e menores diferenças entre elas não ocorreram em uma faixa de horārio definida, variando segundo o dia considerado. Notou-se, no entanto,que as maiores diferenças não ocorreram no inîcio e tampouco no final do período de 


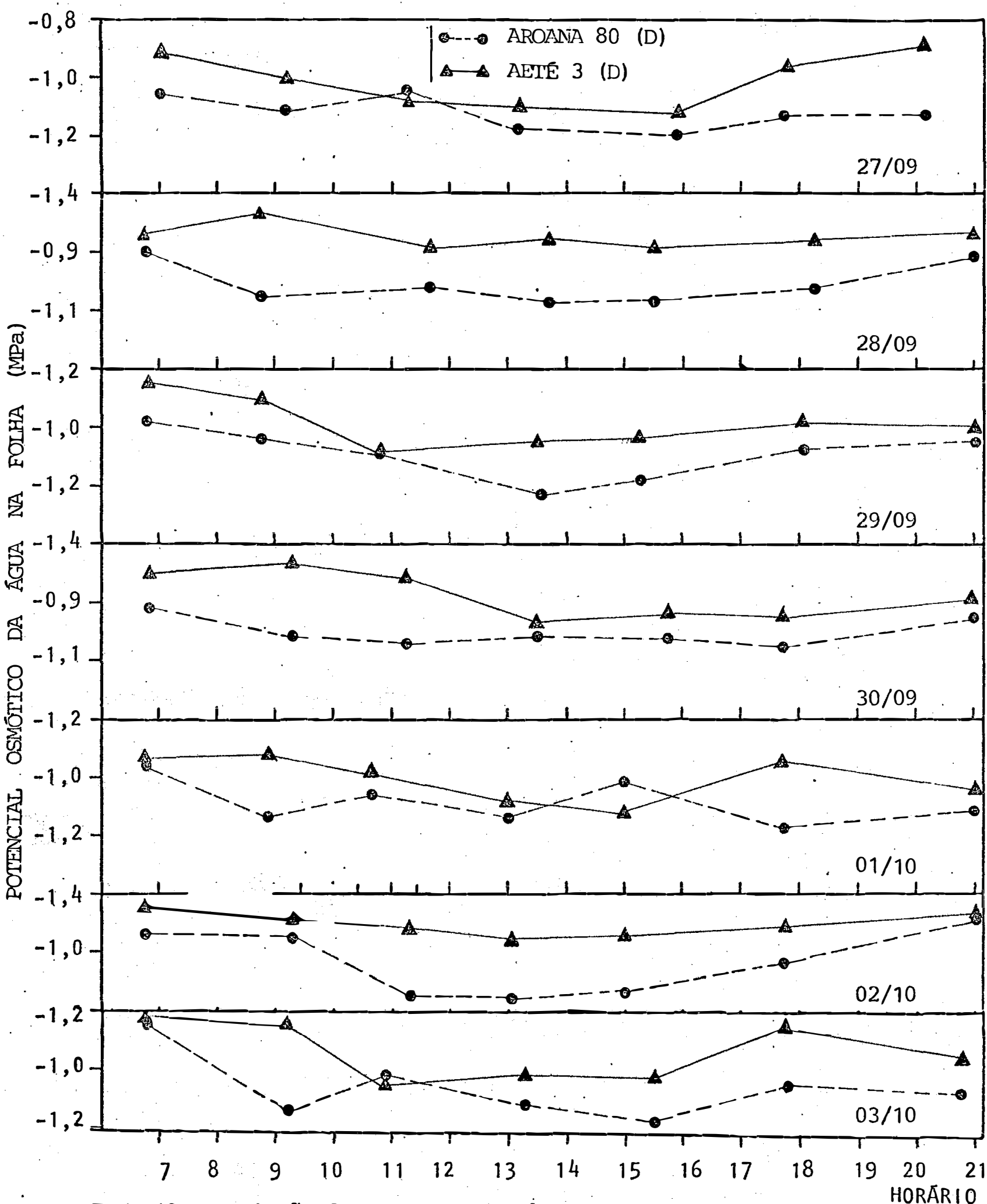

FIG. 19 - Variação do potencial da água na fol ha durante o fotoperíodo e parte do periodo noturno na época de interrupção da irrigação; cada ponto da curva representa a média da segunda e terceira é pocas para as variedades AROANA 80 e AETÉ 3. 
medida (prōximo às 21:00 horas) com exceção do dia 27/09, onde em torno das 20:15 horas a diferença entre as variedades apresentou-se máxima para o dia em questão. Nos dias apresentados não existiu uma tendência da diferença entre variedades apresentar-se no início do período ou no final do período, ou seja, as diferenças entre elas nos extremos das cur vas de variação do $\psi_{0}$, ora foram maiores no inīcio do perīodo, ora foram menores no final do período.

Para a variedade Aeté 3 os valores de $\psi_{0}$ permaneceram entre $-0,75$ e $-1,13 \mathrm{MPa}$ e para a variedade Aroana 80 entre $-0,85 \mathrm{MPa}$ e $-1,23 \mathrm{MPa}$, sendo que estes valores extremos ocorreram em dias diferentes.

Na figura 20 que representa a variação da $\psi_{(0+m)}$ das variedades Aroana 80 e Aetē 3 nas duas épocas de plantio, notou-se uma maior variabilidade dos dados para o Aroana 80 , e que esta variabilidade tendeu a ser diminuîda para ambas com o decorrer dos dias de secamento. Em função desta mesma variabilidade a possīvel tendência de haver amplas diferenças entre épocas não foi visível, somente apresentando-se visĩvel a diferença entre variedades, parecendo ser maior no inicio do ciclo e tendendo a ter uma diminuição em função do progresso do período de secamento salvo para o dia $11 / 10$ no qual tambēm ocorreu uma relativa variabi lidade.

Para a variedade Aroana 80 as médias dos valores iniciais da curva de variação para as duas épocas de plantio não apresentaram grandes diferenças entre um dia e outro nos quatro primeiros dias, permanecendo entre -1,02 $\mathrm{MPa}$ e $-1,15 \mathrm{MPa}$; jā no dia 11/10 este valor médio 


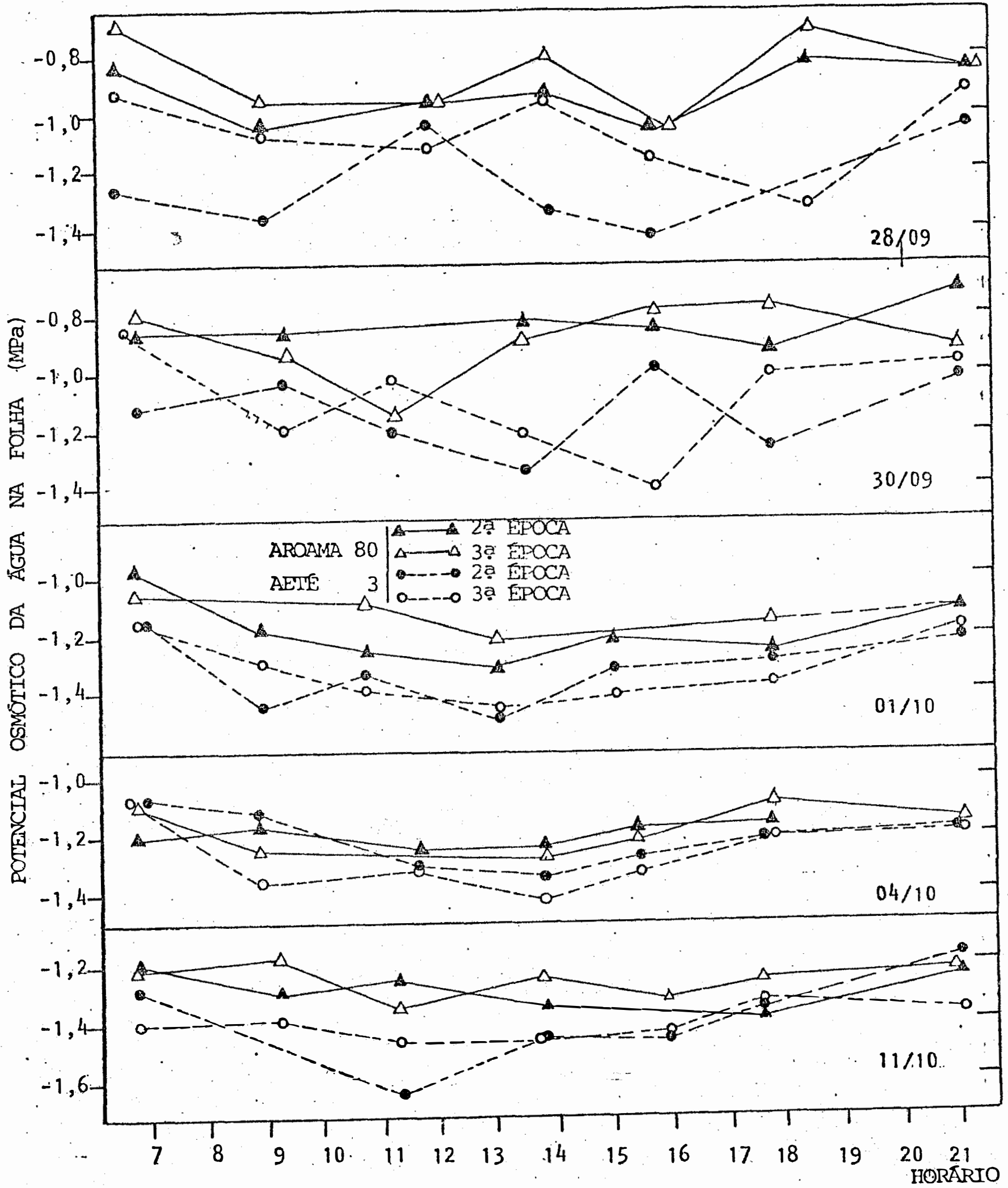

FIG. 20 - Variação da soma do potencial osmótico e matricial da água na fo tha durante o fotoperíodo e parte do periodo notumo na época de interrupção da irrigação, para a variedade AROANA 80 e AETE 3 em duas épocas de plantio. 
esteve prōximo de -1,30 MPa. Para a variedade Aetē 3 as diferenças nos valores entre um dia e outro foram visíveis, sendo que os valores mostraram uma progressiva diminuição desde $-0,77 \mathrm{MPa}$ no dia 28/09, passando pelos valores de $-0,85,-1,02$ e $-1,75 \mathrm{MPa}$ nos dias $30 / 09,01$ e 04/10 respectivamente e atingindo 0 valor de $-1,20 \mathrm{MPa}$ no dia $11 / 10$. Neste horārio, a maior diferença entre épocas e entre variedades ocorreu no dia 28/09, o qual apresentou-se também como o de maior variabilidade ao longo do período de medidas juntamente com o dia 30/09, este com uma variabilidade um pouco menor.

Os valores de $\psi_{(0+m)}$ no final do período de medida, para a variedade Aroana 80, apresentaram-se de maneira crescente com o passar do perīodo de secamento, iniciando com um valor médio de -1,0 MPa no dia 28/09, passando por valores intermediārios nos dias 30/09, 01 e 04/10, atinsindo o valor mínimo de $-1,25 \mathrm{MPa}$ no dia $11 / 10$. Para a variedade Aetē 3, a mesma tendência de comportamento foi apresentada, sendo porém que a amplitude desta variação foi maior, desde um valor médio de -0,86 $\mathrm{MPa}$ no dia 28/09 até um valor de -1,24 MPa no dia 11/10, passando por valores intermediārios nos demais dias. Em geral os potenciais no fim do período de medida foram menores que os do início do período, mostrando falta de recuperação total da planta atē ao redor das 21:00 horas, ex ceção sendo feita nos dias 28/09 e 11/10 para a Aroana 80 e no dia 30/09 para a variedade Aeté 3. Para uma caracterização do período pode-se afirmar que os dias 28 e 30/09 apresentaram-se como os de maior variabilidade e os dias restantes como os de menor variabilidade. 


\subsubsection{Valores dos parâmetros de água no solo}

Nas figuras 21 e 22 sãomostradas as variações do potencial ma tricial da água no solo durante o período luminoso nas profundidades de $15,30,45,60$ e $75 \mathrm{~cm}$. Para cada dia são apresentadas somente as curvas de resposta na profundidade que apresentou variação significativa e na imediatamente inferior.

Em todos os tratamentos em que a irrigação foi cessada a variação do potencial matricial ocorreu principalmente nas camadas super ficiais, iniciando-se com a profundidade de $15 \mathrm{~cm}$ e passando sequencialmente às profundidades maiores, para ambas as variedades e épocas de plantio. A variação significativa do potencial durante o dia em uma determinada profundidade iniciou-se, em mēdia, 1 a 2 dias apōs o potencial matricial da camada imediatamente superior ter atingido o limite mensurā vel pelo tensiómetro, salvo para as camadas de 45,60 e $75 \mathrm{~cm}$ na terceira época do Aroana 80 e na segunda época do Aeté 3 , que apresentaram variações simultāneas para as referidas profundidades.

Na segunda época de plantio, o potencial matricial atingiu o valor limite mensurāvel pelos tensiōmetros na profundidade de $15 \mathrm{~cm}$ um e dois dias antes que na terceira época, respectivamente para o Aroana 80 e Aeté 3. Na profundidade de $30 \mathrm{~cm}$, essa tendēncia permaneceu para - Aetē 3 mas não para o Aroana 80 , onde as datas em que o valor limite foi atingido é a mesma nas duas épocas, sendo que nestas variedades tambēm não houve diferença significativa entre o comportamento do potencial matricial nas duas épocas para a profundidade de $45 \mathrm{~cm}$. Já na camada de 

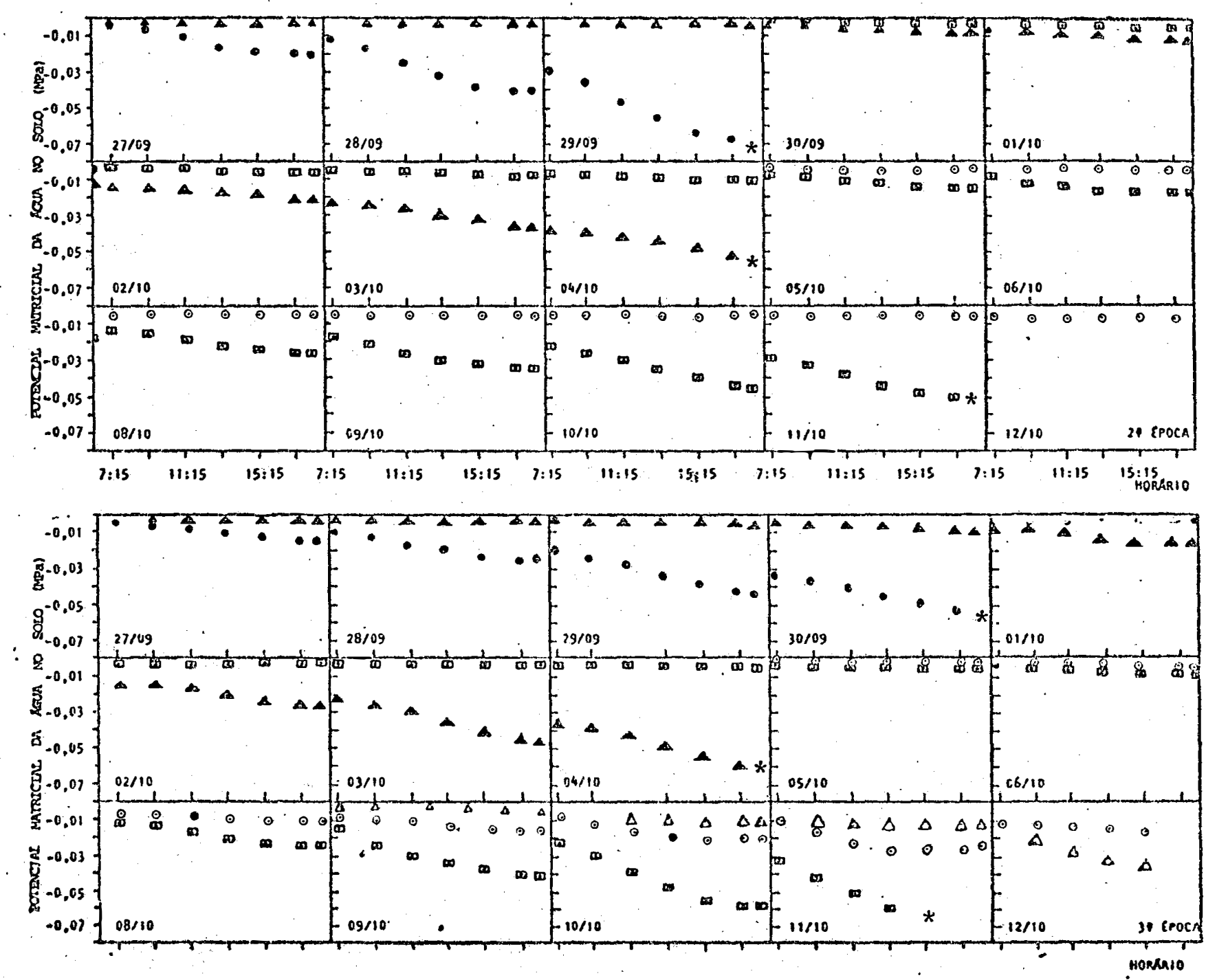

FIG. 21 - Variações horárias do potencial matricial da água no solo durante o pe ríodo luminoso nas profundidades de 15 (•), 30 (\$), 45 (四), 60 (•) e $75(\Delta) \mathrm{cm}$, para a variedade AROANA $80 \mathrm{em}$ duas êpocas de plantio durante o período de interrupção da irrigação. o símbolo (*) representa o último valor determinado antes de ser atingido o limite mensurável pelos tensiômetros. 

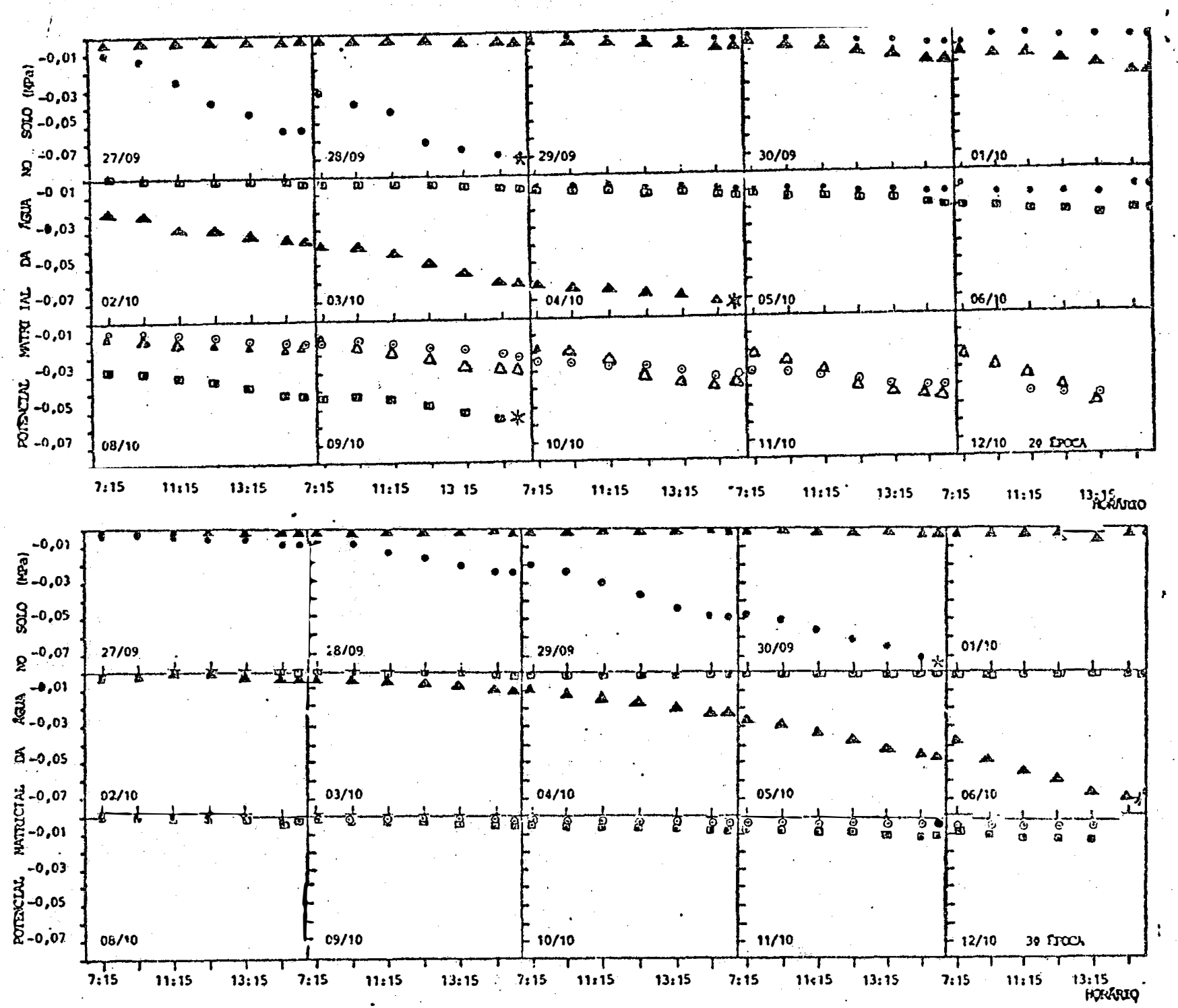

FIG. 22 - Variações horárias do potencial matricial da água no solo durante o pe

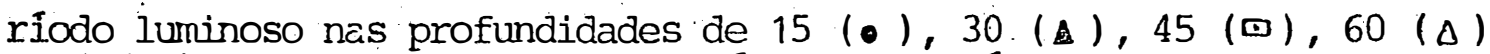
e $75(\circ) \mathrm{cm}$, para a variedade AETE 3 em duas épocas de plantio durante o periodo de interrupção da irrigação. O símbolo $(*)$ representa o último valor determinado antes de ser atingido o limite mensurável pelos tensiômetros. 
$60 \mathrm{~cm}$ houve diferença entre as duas épocas de plantio nessa mesma variedade.

Para o Aetē 3 , as profundidades de 45 e $60 \mathrm{~cm}$ apresentaram variações diferentes com o passar dos dias durante o período de secamento, tendo a terceira época de plantio apresentado valores superiores de $\psi_{\mathrm{m}}$ atē o final deste período.

Comparando as variedades dentro da mesma época de plantio, observou-se que na segunda época, na profundidade de $15 \mathrm{~cm} 0$ Aeté 3 atingiu o valor limite mensurāvel um dia antes que o Aroana 80, não havendo diferença de data na profundidade de $30 \mathrm{~cm}$, embora nesta profundidade o Aeté 3 tendesse inicialmente à um decréscimo mais rápido de $\psi_{m}$. Quanto às camadas mais profundas, o valor limite foi atingido no Aetē 3 dois dias antes que no Aroana 80 à $45 \mathrm{~cm}$, e na profundidade de $60 \mathrm{~cm}$ a variação na primeira variedade foi maior que na segunda à partir :o dia 04/10, embora atē o dia 12/10 não fosse atingido o valor limite. Na terceira época, não houve diferenças tão acentuadas entre as duas variedades na profundidade de $15 \mathrm{~cm}$, mas a $30 \mathrm{~cm}$ o decréscimo de $\psi_{\mathrm{m}}$ no Aroana 80 foi mais rápido, atingindo o valor limite dois dias antes que no Aeté 3. Nas camadas de 45, 60 e $75 \mathrm{~cm}$ essa tendência de diminuição mais brusca do potencial matricial no Aroana 80 manteve-se, pois na profundidade de $45 \mathrm{~cm}$ foi atingido o valor limite no dia $11 / 10$, o que não aconteceu no Aetē 3 , que manteve potenciais altos nessa profundidade e também a 60 e $75 \mathrm{~cm}$ até o final do período de secamento. Em todos os tratamentos ocorreu uma recuperação do potencial da água do solo durante o período noturno, recuperação esta que foi no māximo de 0,026 $\mathrm{MPa}$. Esta recuperação 
foi detectada somente nas camadas onde a variação do potencial foi ampla durante o perīodo luminoso e de modo geral apresentou um acréscimo gradual a medida que os potenciais aproximaram-se dos limites mensurāveis pelos tensiômetros. Como esta recuperação ocorreu somente quando a variação do $\psi_{m}$ foi ampla, primeiramente se deu na camada de $15 \mathrm{~cm}$. Dentre todos os tratamentos, o que apresentou menor variação nesta camada foi a terceira época da variedade Aeté 3 , sendo maior para a terceira época da mesma variedade. Independente da variedade, a recuperação foi sempre maior para a segunda época de plantio. Com relação à variação dos potenciais nas camadas inferiores, notou-se que foi maior para a segunda e terceira épocas da variedade Aetē 3 e Aroana 80, respectivamente, onde as trēs profundidades inferiores $(45,60$ e $75 \mathrm{~cm})$, variaram conjuntamente. Na segunda e terceira épocas da variedade Aroana 80 a camada mais inferior que apresentou uma variação visĩvel foi a de $45 \mathrm{~cm}$ sendo que esta mesma variação foi maior para a segunda época. Para estes mesmos tra tamentos os potenciais nas camadas de 60 e $75 \mathrm{~cm}$ näo demonstraram variações significativas.

Para a camada de $30 \mathrm{~cm}$ a recuperação de $\psi_{\mathrm{m}}$ durante 0 período noturno foi quase imperceptivel, somente notada para a terceira época da variedade Aroana 80.

A figura 23 mostra a variação da fração de āgua disponīvel (FAD) para os tratamentos Aroana 80 (I) e (D) e Aeté (D) durante o perĩodo de secamento e nas trēs épocas de plantio, para um perfil com profundidade de $47 ., 5 \mathrm{~cm}$ Com relação às diferenças da FAD provocada pelos tratamentos de défice hĩdrico, observa-se que na primeira e terceira 


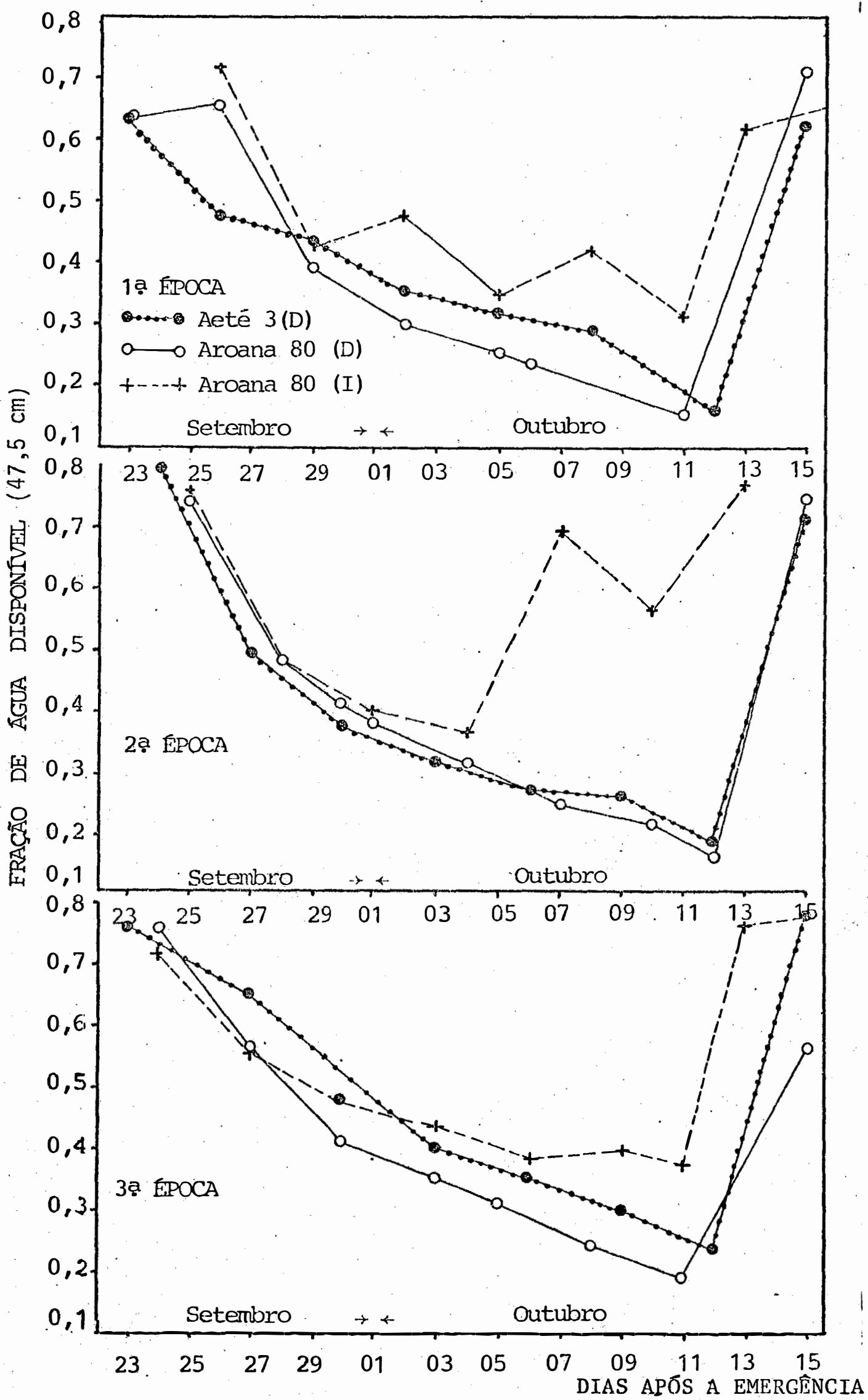

FIG. 23 - Fração de āgua disponīvel no solo para um perfil com profundidade de $475 \mathrm{~mm}$ durante 0 perĩodo de interrupção da irrigação em diferențes tratamentos. 
ëpocas o tratamento Aroana 80 (D) apresentou valores menores em relação ao tratamento Aetē 3 (D) e na segunda época os valores são aproximadamente iguais. As diferenças entre o tratamento Aroana 80 (I) e os demais foram maiores dentro da segunda época; nas duas outras épocas estas diferenças foram aproximadamente as mesmas.

Para o tratamento Aroana 80 (I) os valores mīnimos atingidos no perīodo foram de 0,31,0,36 e 0,37 para a primeira, segunda e terceira épocas, respectivamente, sendo que na primeira e segunda épocas os valores da FAD permaneceram inferiores em relação à segunda época por um período maior.

0 tratamento Aroana 80 (D) apresentou valores minimos de FAD de $0,15, \quad 0,15$ e 0,20 para a primeira, segunda e terceira épocas de plantio, respectivamente. Os valores de $F A D$, quando da progressão do perĩndo c'e secamento, não apresentaram diferenças significativas entre épocas neste tratamento, havendo uma diferença quando da retomada do pro cesso de umedecimento do solo apōs o dia $11 / 10$, pois na terceira época de plantio a FAD atingiu o valor de 0,56 inferior à média de 0,7 obtida nas duas outras épocas.

Para o tratamento Aeté 3. (D) os valores mínimos atingidos foram de $0,15,0,15$ e 0,25 para a primeira, segunda e terceira épocas respectivamente. Com relação ao comportamento da FAD durante o avan ço do período de secamento, notou-se uma tendência de a segunda época ter apresentado valores menores ao longo do perīodo em relação às demais, sendo que na primeira época mostrou-se com tendência de permanecer com valores intermediārios. 
5. DISCUSSÃO

5.1. Dos Resultados Relativos a todo o Ciclo de Desenvolvimento das Culturas

Comparando-se os tratamentos com e sem suspensão de irrigação, denominados de (D) e (I) respectivamente, nos diferentes estādios de بeserivolvimento dentro da variedade Aroana 80, na qual os balanços hi dricos no campo foram realizados em ambas as condições de regime de suprimento hídrico do solo, verificou-se que a diferenciação quanto à evapotranspiração acumulada (ETc) dentro de cada época, ocorreu de modo sig nificativo, como seria esperado, a partir do inīcio do período de suspensão da irrigação, em consequência das diferentes condições de disponibilidades hídricas no solo entre os dois tipos de tratamento.

As maiores taxas de evapotranspiração das culturas constantemente irrigadas, indicadas pela inclinação das curvas de ETc nas fí guras 4, 5 e 6, ocorreram em períodos com maiores taxas de acréscimo de Etp, indicando que a resposta nos tratamentos irrigados foi função de 
ampla disponibilidade hîdrica no solo e das condições de alta demanda evaporativa da atmosfera, enquanto que nos tratamentos que sofreram interrupção da irrigação a diminuição da ETc ocorreu tanto pela diminuição da transpiração devida a uma menor disponibilidade de āgua na zona radicular, como pela diminuição da evaporação do solo devida ao aumento da resistência deste ao processo evaporativo, conforme discutem BLACK " et alii (1970b).

As condições de alta demanda evaporativa da atmosfera ocorreram em estádios distintos das culturas conforme a época de plantio: maturação fisiológica, inīcio do florescimento e inīcio de formação de vagens na primeira, segunda e terceira época. respectivamente.

A ocorrência deste período de alta demarida em fases distintas da cultura mostrou que a al ta taxa de ETC neste período, nos tratamentos irrigados, foi função tambēm das taxas de crescimento da cultura, jā que a maior taxa de acréscimo da ETp coincidiu com a maior taxa de acúmulo de matéria seca, quando comparadas entre si, sendo que a maior taxa de acréscimo da ETp ocorreu na terceira época de plantio, seguida da segunda e da primeira, respectivamente. No restante do ciclo a relação entre a evapotranspiração (ETC) dos tratamentos (D) e (I) na variedade Aroana 80 foram prōximas à unidade, e a maior diferença ocorrida entre eles com respeito à ETc antes da aplicação do tratamento de suspensão da irrigação, na primeira época de plantio coincidiu com a maior diferença de matēria seca acumulada. 
A inexistēncia de diferença na evapotranspiração acumulada entre os tratamentos Aroana 80 (I) e Aroana 80 (D) nos perĩodos iniciais do crescimento vegetativo da cultura pode ser questionada, caso se observe que a fração de āgua disponīvel (FAD) (figura 2) atingiu nos primeiros vinte dias apōs a emergência valores em torno de 0,50 a 0,45 no tratamento Aroana 80 (I), contra valores maiores no tratamento Aroana 80 (D), principalmente na primeira época de plantio. Entretanto, devese considerar que a fração de āgua disponível apresentada refere-se a um perfil de solo de $675 \mathrm{~mm}$, o qual inclui profundidades onde a efetividade de absorção hîdrica pelas raîzes, em tal estādio de crescimento é pequena, de modo que F.A.D. não caracteriza nesse caso a alta umidade existente nas camadas mais superficiais do solo. A inexistência de restrição hîdrica na fáse inicial de crescimento das culturas, em qualquer um desses tratamentos pode ser confirmada pelo fato de que o crescimento das culturas, expresso em peso de matéria seca por unidade de ārea de terreno (figura 7) praticamente não se diferenciou até cerca de 25 dias após a emergēncia no Aroana 80 , nos dois tratamentos de regime hídrico no so10 e nas trēs épocas de plantio.

Embora os valores de F.A.D., no período compreendido entre a emergēncia e a primeira elevação da umidade do solo aparentemente, possam se apresentar semelhantes àqueles do período de retirada da irrigação, em termos de restrição hỉdrica eles não o são, pois no primeiro perĩodo considerado as camadas inferiores do solo encontravam-se com baixos teores de āgua disponível e a quantidade de āgua aplicada por irrigação ficou retida nas camadas superiores do solo. Durante o período 
de secamento, a situação era inversa, ou seja, as camadas superficiais (na zona de maior concentração das raîzes) continham uma F.A.D. menor que as camadas inferiores. A situação apresentou-se desta maneira pelo fato de que no período de prē-plantio a não ocorrēncia de precipitação pluvial condicionou o secamento de todo o perfil do solo, enquanto no perīodo anterior à retirada da irrigação, a frequência e a intensidade re lativamente elevadas de precipitação provocaram a saturação do solo, in clusive com valores significativos de drenagem na profundidade de $675 \mathrm{~mm}$.

Tambēm é necessārio considerar que a mesma diferença de FAD em termos de valores absolutos dentro de uma faixa com ampla disponibilidade hîdrica (altos potenciais da āgua na zona de efetividade das raīzes) è diferente em termos de influência no crescimento e desenvolvimento da cultura, em relação a uma mesma diferença em faixas de F.A.D. onde a absorção da água pela planta jā estā sendo restringida. Por outro lado, estas diferenças, mesmo dentro de uma faixa de F.A.D. que não seja ampla, terão influências distintas de àcordo com as condições de demanda da atmosfera vigentes no período considerado, DENMEAD e SHAW (1962), DOORENBOS e KASSAN (1979).

As diferenças entre a ETpe a ETc ocorridas em todas as épocas e variedades poderiam ser questionadas quanto à validade da estimativa da ETm pelo método de PENMAN (1948). No entanto, tal método foi utilizado como um parāinetro de comparação e não como um método de estimativa da ETm, jā que o balanço de energia foi determinado em fases nas quais a cultura cobria amplamente o solo, sendo estes mesmos valores extrapolados, em função da radiação solar global, para as fases iniciais e 
finais da cultura; tal procedimento ocasionou a obtenção de valores superiores e inferiores para a ETp em relação à ETc, no início e final do ciclo da cultura, respectivamente.

Com relação às diferenças da evapotranspiração (ETC) entre as variedades, podem ser divididas em duas fases; uma referente ao perīodo de não restrição de āgua no solo e outra durante o período de restrição hỉdrica. As diferenças entre elas com relação aos parāmetros estudados durante o período de interrupção da irrigação serão discutidas no item 5.2. As diferenças notadas entre as variedades no início do ciclo, com respeito a evapotranspiração, foram pequenas e talvez estejam dentro do erro experimental; a existencia dessa igualdade provavelmente seja devida ao pequeno estāgio de desenvolvimento da cultura, com as mes mas apresentando baixos valores de matēria seca total e, consequentemente, baixos valores de IAF, provocando com isto uma maior taxa de evaporação do solo, valores estes muito maiores que os de transpiração, sendo que uma possīvel desigualdade decorrente de uma diferença de comportamento apresentado pelas variedades seja diluĩda e não significativa, em vista dos valores de ETC apresentados.

As diferenças entre as variedades quanto a ETc que se apresentaram apōs o período inicial de desenvolvimento dás culturas, em que os valores foram semelhantes, não correspondem a um resultado esperado se considerados os valores de F.A.D. e de matéria seca total, porém os valores de resistência estomática à difusão de vapor, pctencial da àgua na planta e outros parāmetros, os quais serão discutidos no item 5.2., poderão explicar em parte as diferenças encontradas. 
Quanto ao acúmulo de matéria seca total por unidade de superfīcie de terreno pelas variedades, em relação à influência dos diversos tratamentos, notou-se que as variedades Aroana 80 e Aeté 3 apresentaram respostas diferentes com respeito a épocas e quanto ao efeito da suspensão da irrigação. Enquanto que para a variedade Aroana 80 ocor reu uma diferenciação entre ēpocas, esta diferença não foi caracterizada na variedade Aetē 3. A diferença gradual entre as épocas em função da data de plantio teve a contribuição de um início de surto de ferrugem do feijoeiro (Uromyces phaseoli) que provocou uma ligeira redução na ārea foliar fotossinteticamente ativa, sendo que a mesma foi mais intensa na primeira época de plantio, intensidade esta gradativamente menor na segunda e terceira épocas.

Por outro lado, apesar de ambas pertencerem ao grupo II, segundo a classificação do boletim de caracterização das variedades (IAC, 1982) as mesmas apresentaram comportamentos distintos, tanto por ocasião de ampla disponibilidade de água quanto por ocasião do período de restrição hĩdrica no solọ. A variedade Aroana 80 apresentou häbito de crescimento e estádio de florescimento mais definidos em relação a Aetē 3 , ou seja, sua taxa de acūmulo de matéria seca foi intensamente di minuĩda ou mesrio paralisada durante tal estádio enquanto que a variedade Aeté 3 apresentou a emissão de uma guia vegetativa por ocasião. do florescimento e um período de florescimento com limites não tão definidos. Isto pode ser confirmado pelas curvas representativas do acúmulo de matēria seca das variedades (figura 7) onde a variedade Aroana 80 apresenta um patamar quase no final do ciclo e logo em seguida uma taxa 
negativa de acúmulọ de matéria seca; a variedade Aetē 3 , por sua vez, não apresenta este patamar e a taxa de acúmulo de matéria seca é sempre positiva, considerando o período de amostragem. Outro fato que leva a esta conclusão ē que ambas tiveram a mesma duração do ciclo dentro de cada época nos tratamentos sem suspensão da irrigação. 0 comportamento das variedades no que diz respeito ao hābito de crescimento, quando da suspensão da irrigação, serā discutida no item 5.2.

Os menores valores de ETC acumulada, apresentados na ta bela 1, dentro dos tratamentos em que foi suspenso o fornecimento de āgua ocọrreram na terceira época de plantio, sendo também esta que apresentou a maior redução relativa da taxa de acúmulo da matéria seca total, principalmente na variedade Aroana 80.

Os maiores valores de ETC acumulada durante 0 estādio compreendido entre a emergência e o início do aparecimento das gemas florais, em relação àquele compreendido do inīcio da formação de grãos à maturação fisiológica, nos tratamentos sem restrições de āgua no solo, foram devidos à maior duração do primeiro estádio em relação ao ūitimo considerado.

5.2. Dos Resultados Relativos ao Perīodo de Diferenciação dos Tratamentos de Agua no Solo.

Os dados apresentados nas figuras 12 e 13 que mostram a variação da resistēncia estomática à difusão de vapor durante o fotoperĩodo, bem como dos parāmetros da planta (potencial da água na planta) e da atmosfera (radiação solar e dēfice de pressão de saturação de vapor 
de àgua) a ela relacionados, permi tem uma discussão quanto a interrelação desses parâmetros.

A resistēncia estomātica à difusão de vapor é uma proprie dade da epiderme, determinada pelo número e dimensão dos estōmatos, que permitem a transferência de vapor d'água para a atmosfera, o que deve explicar o fato dessa resistēncia ter sido constantemente menor na face inferior em relação à superior, pelo maior número de estômatos encontrado na face inferior das folhas de feijoeiro (KANEMASU e TANNER, 1969a).

0 fato de a resistência estomātica à difusão de vapor ter sido definida através da razão entre a diferença de pressão de vapor da folha e do ar adjacente e a densidade de fluxo transpiratório, permite algumas observações. As figuras 12 e 13 mostram que 0 aumento da radiação solar e do défice de saturação de vapor de āgua do ar causaram um aumento na transpiração com uma diminuição da resistēncia estomática a tē o meio do dia na maior parte dos dias apresentados. No dia 03/10, no qual o défice de saturação e a radiação solar global foram moderados e no dia $02 / 10$, em que os valores desses parâmetros foram baixos houve uma tendēncia da resistência estomática à difusão de vapor na face superior da folha manter-se ainda alta quando o período matinal avançou até cerca de as 10:00 horas, e de se elevar em torno das 15:00 horas, sendo que esta elevação no período vespertino ocorreu, na face superior, em quase todos . os dias.

A tentativa, neste trabalho, de se relacionar a densidade de fluxo transpiratório, potencial da água na planta e resistēncia estomática à difusão de vapor com a finalidade de determinar um nível de 
energia da āgua na folha que afetasse os outros parâmetros não foi satisfatória no sentido de estabelecer valores críticos.

A dificuldade de obter relações satisfatōrias entre os pa râmetros a um nīvel de detalhamento mais profundo è perfeitamente justificada pois o comportamento das plantas quanto ao transporte de āgua, suas relações e reações são complexas. Até recentemente existia o consenso de que o controle estomático das relações hîdricas na planta era determinado exclusiliamente pelo processo de retroalimentação ("feedback") ou seja, os estōmatos responderiam não àqueles fatores externos que influenciam a taxa de perda de āgua, sendo afetados em ūltima anālise pela taxa de transpiração. Atualmente admite-se a presença de um processo ("feedforward") onde o estado de turgescēncia das cēlulas guardas são afetados diretamente pelos elementos atmosféricos, (COWAN, 1977) e FARQUHAR, 1978). Porém, a anālise das reações da planta a este respeito è complexa e ainda existe grande dificuldade em separar, para efeito de anālise, os dois processos; por outro lado, em condições naturais os parāmetros do meio não permanecem constantes e muitas vezes a planta res ponde $a$ interações entre eles, segundo os autores.

Nota-se pelos dados que, mesmo com a diminuição do potencial da àgua na folha à níveis relativamente baixos, a resistência estomātica à difusão de vapor e a densidade de fluxo transpiratōrio não apre sentaram variações bruscas em função da variação do potencial da āgua na folha $\left(\psi_{t}\right)$. Os resultados mostram que a variação de $\psi_{t}$, no entanto, foi influenciada pelo défice de saturação de vapor de ăgua e pelo fluxo de radiação solar ao iongo do período. 
Com respeito ao comportanento estomätico em funçio da uni dade do ar, Schulze et alie (1972), citado por CONAN (1977), trabaihando com plantes de clima desêricico demonstraram que a resistēncia estomätica à difusão de vapor era aumentada com o decrëscimo de unidade do ar e diniriúda con o aumento da umidade do ar. Também foi observado que em temos relativos, o grau de redução da densidade de fluxo transpiratörio era menor que o da resistencia estomätica e que com a reduçäo da taxa de transpiração o conteüdo de ägua na folha era aumentado. Através do controle das conalçôes do ambiente verificaram tambëm que, em condi.. çôes de alta unidade do ar, apesar do potencial da ägua na fotha ser baj \%o, o estomato permanecia aberto e que com baixa umifade do ar, apesar do potencial de água ser alto os estomatos fechararn. Isto levou os autores a concluir que a aberinc escomatica nas especies estudadas era governada pelas condiços de demanda evaporativa da atmosfera.

LANGE at abie (1971), trabalhando também com planta xeromōrfica, mostraram que o fechamerto e aberiura estomätica podian ser causados pelo decréscimo e acrésciriso da unidade do ar, respectivamente. Porëm neste estudo deve-se levar em consideração que o comportamento era relativo a una parcela do tecido da fotha na qual a parte inferior (subepicierme) havia sido destacada a o tecido en questão fiutuava en! ägua. Quando era introduzida uma boina de ar entre a superfície do Tiquido e o tecido, as respostas estomäticas aos jatos de ar com diferentes niveis de umidade eram imediatas, quando a bolina de ar era suprimida, os estōmatos não respondiam às variaçñes de umidade. 
Ao verificarem o comportamento estomātico de três espēcies do deserto de Negeve (Israel), sendo uma com folhas mesomōrficas, outra com folhas xeromörficas e uma com folhas suculentas, SCHULZE et alii (1972) verificaram que durante o fechamento dos estōmatos à baixa umidade do ar, o teor de āgua da folha da espécie mesomórfica aumenta, o contrārio ocorrendo quando da abertura estomática, o que permite excluir estar a reação do estōmato ocorrendo atravēs das variações do teor de āgua na folha.

Os trabalhos citados confirmam que o comportamento estomātico dependeu mais das relações hĩdricas da epiderme, quando afetada pela umidade do ar, do que da hidratação do mesófilo, podendo explicar parcialmente a falta de relação da resposta estomática e o estado de hidratação da folha (SHERIFF e SINCLAIR, 1973); SHERIFF, 1974). Para verificar a influência do contato hidräulico entre o mesōfilo e a epider me e a influência no comportamento estomático, SHERIFF e MEIDNER realizaram medidas de condutância hidrāulica em tecidos foliares numa espécie mesomórfica e em uma xeromórfica, verificando que nas folhas mesomōrficas o suprimento de āgua da epiderme está bastante ligado com o tecido vascular, podendo haver um certo grau de conexão entre o potencial da água no mesófilo com o da epiderme, e portanto com a abertura estomātica; nas folhas xeronōrficas, sem extensões de veias e bainhas vasculares, a resistência ao fluxo hỉdrico à epiderme è relativamente alta e o potencial da água da epiderme e, por conseguinte, a abertura es tomātica, é dependente em maior grau da transpiração cuticular (determinada pela umidade do ar) do que do estado de hidratação do restante da folha. 
Trabalhos posteriores em uma série de espécies cultivadas confirmam a hipōtese de que o estômato responde diretamente ao défice de saturação do vapor da água do ar. BLACK e SQUIRE (1979) afirmam que a resposta ē mais acentuada em espécies lenhosas e em espécies xeromōrficas, embora dicotiledoneas herbāceas, como girassol, beterraba, feijāo e fumo apresentem-na em alto grau.

Para o feijoeiro MOLDAU e SYBER (1974) mostraram que quando o solo encontrava-se com alta umidade a condutância estomática à difusão de vapor foi mais elevada para ambientes úmidos (umidade relativa de $80-90 \%$ ) e menor para ambientes mais secos (urnidade relativa de 20-30\%); no entanto quando a planta era condicionada ao ar mais seco e somente uma folha desta era condicionada ao ar ümido, esta mesma folha tinha um valor de condutância de 2,5 vezes menor em relação àquele quando a planta estava em ambiente úmido mesmo estando submetidas a condições idênticas de radiação fotossinteticamente ativa e concentração de $\mathrm{CO}_{2}$. Mostra o trabalho desses autores que o comportamento estomático não ē puramente um fenômeno local e que depende das condições de transpiração das folhas situadas acima e abaixo daquela considerada.

HOFFMANN et alii (1978) quando submeteram plantas de feijoeiro a ambientes quente e seco (temperaturas entre 23 a $32^{\circ} \mathrm{C}$ e umidade relativa de $35 \%$ ) e frio e úmido (temperaturas entre 19 a $25^{\circ} \mathrm{C}$ e umidade relativa de 80 a 90\%) crescendo em soluções nutritivas com vārias concentrações, verificaram que a condutāncia estomātica se relacionou de ma neira linear com os potenciais totais, osmótico e de pressão das folhas, exceto no ambiente quente e seco das plantas que se desenvolviam nas 
soluções com altas. concentrações salinas. Independentemente da concentração da solução nutritiva; a resistēncia estomātica à difusão de vapor foi mais alta em ambiente frio e úmido do que no ambiente quente e seco.

Deve-se levar em consideração que os autores trabalharam em condições controladas e nas quais os parâmetros de atmosfera eram extremos e constantes durante um determinado periodo. No presente experimento as diferenças notadas com relação aos parāmetros do meio nos dias de medida ñão foram tão amplos e mesmo para diferenças extremas, como en tre o dia 02/i0 e um outro dia qualquer apresentado, salvo o dia 03/10 onde os valores de temperatura média diurna foram inferiores aos demais e os valores de resistência média os maiores em relação aos dos demais dias, não notou-se aquele padrão de comportamento. Dentro de um mesmo dia, a variação da resistēncia estomātica à difusão de vapor, analisada com relação à variação do défice de saturação de vapor, é dificultada pela prōpria variação dos demais parāmetros.

Para MOLDAU e SYBER (1975) dificilmente uma variação uniforme ou padrão pode ser esperada nas respostas estomāticas às variações da umidade do ar., porque o comportamento também dependerā do tipo de solo, espécie de planta e condições de cultivo.

0 comportamento diferente da resistência estomātica ao longo dos dias 01/10 e 03/10 em relação aos demais, parecem advir da variação da radiação solar global, embora não se possamexcluir os efeitos dos outros parāmetros, entre eles o défice de saturação do vapor de água e temperatura do ar que afetam a demanda evaporativa. Esses dois dias 
apresentaram condições semelhantes de radiação solar porēm condições di ferentes de défice de saturação de vapor de āgua do ar, esses valores para os dois parâmetros mostraram-se intermediārios em relação àqueles dos demais dias.

Existe uma dificuldade, no entanto, em determinar a influência da densidade do fluxo de radiação solar no comportamento estomático, pois nîveis baixos ou nulos de densidade provocam o parcial ou total fechamento estomático, respectivamente, tal como verificado por KANEMASU e TANNER (1969b) em feijoeiro. No entanto esta resposta pode ser alterada em função da faixa de potencial da āgua em que sè encontra a folha tal como comprovado por Kassan (1973) citado por COWAN (1977) em Vicia faba, a qual en condições de alta demanda evaporativa para a faixa de potenciais entre $-0,2$ a $-0,7 \mathrm{MPa}$ e altas densidades de fluxo de radiação, a resistência estomātica à difusão de vapor diminuiu e na faixa de potenciais entre $-0,0-0,7 \mathrm{MPa}$ com densidade de fluxo menores de radiação as resistências estomáticas aumentaram. Por outro lado, mesmo em condições de luminosidade constante podem ocorrer variações nos vạlores da resistência estomātica à difusão de vapor, devido a ritmos endógenos, segundo constatação de KANEMASU e TANNER (1969b). Para os dados observados no presente trabalho os valores de resistência à difusão de vapor d'água, em termos médios, foram menores por volta de meio dia e o acrés-. cimo dós valores no fim ou início do fotoperīodo, mesmo quando o nível de radiação não era limitante, pode ser função de ritmos endógenos e/ou das relações hĩdricas decorrentes do meio ambiente. 
Alēm da variação diferencial em relação aos demais dias da densidade de fluxo de radiação para os dias $01 / 10$ e $03 / 10$, neste ūltimo ocorreu a menor temperatura mëdia e neste dia os valores da resistência estomática para a face abaxial apresentaram os maiores valores de todo o período de medida. Os resultados verificados no presente estudo quanto aos efeitos da temperatura sobre a abertura estomática concordam parcialmente com aqueles encontrados na literatura, pois HOFSTRA e HESKETH (1969) observaram em feijoeiro que a abertura estomätica foi função quase linear da temperatura e que a $21^{\circ} \mathrm{C}$ a abertura estomática na face superior foi prōximo de zero e na face inferior foi mînima, e com temperaturas elevadas $\left(30\right.$ a $36^{\circ} \mathrm{C}$ ) a diferença de aberturà estomática entre as faces não era significativa. Por sua vez WILSON (1975) observou que a abertura estomática foi maior a temperaturas baixas $\left(5^{\circ} \mathrm{C}\right)$ do que a temperaturas mais altas $\left(25^{\circ} \mathrm{C}\right)$ e HIRON e WRGHIT (1973) afirmam que jatos de ar quente a $38^{\circ} \mathrm{C}$ causam o fechamento estomático.

Contudo, deve-se considerar que a temperatura da folha não ē necessariamente sempre causa do movimento estomätico, pois estando relacionada com a transpiração deve-se tomar cuidado para que tal parâmetro, sendo na verdade um efeito do comportamento estomático afetado por outros fatores, não seja tomado como causa. Exemplos de que nem sempre hā uma associação direta entre a variação de temperatura da cober tura vegetal e a abertura estomática em feijoeiro podem ser encontrados em WALKER e HATFIELD (1979).

Atravēs dos dados do presente experimento não foi possīvel caracterizar um nível crítico de potencial da água na folha para a 
abertura estomática. Quanto a isto pode-se afirmar com segurança que os valores encontrados de $\psi_{t}$, $\psi_{o}$ e $\psi_{p}$ não necessariamente devem estar em uma faixa em que éstá contido o potencial da àgua crítico, pois existeni uma série de fatores que interferem na relação entre potencial da āgua e abertura estomática. DAVIES (1977) e COWAN (1977) afirmam que o potencial de água crítico varia de acordo com a idade e condições de cres cimento das plantas. Em complemento,o ūitimo autor cita experimento com algodoeiro' realizado por TURNER e BEGG (1973), e TURNER (1974a), no qual o potencial da āgua na folha considerado critico foi de -1,6 $\mathrm{MPa}$ em casa de vegetação e de $-2,7 \mathrm{MPa}$ em condições de campo. Os autores sugerem que talvez esta diferença pode ser ocasionada por uma maior capacidade das plantas no campo manterem um potencial de pressão $\left(\psi_{p}\right)$ mais elevado, atravēs de uma maior variação do potencial osmōtico $\left(\psi_{0}\right)$.

Por outro lado COWAN (1977) e Begg e Turner (1970a) citados por TURNER (1974) sugerem que os valores criticos de $\psi_{t}$ seriam melhor relacionados com os valores de $\psi_{\mathrm{p}}$; e os ūltimos autores mostram que a condutāncia estomática apresenta somente pequenas variações atē que o $\psi_{p}$ atinja uma faixa entre 0 e $+0,3 \mathrm{MPa}$, na qual os valores de condutância estomática são diminuĩdos.

No presente estudo, os valores médios de $\psi_{\mathrm{p}}$ permaneceram na maioria dos dias acima de $+0,5 \mathrm{MPa}$, o que justifica o fato de não se obter uma relação entre esse parâmetro e a resistência estomātica.

Ao tentar relacionar a resistēncia estomātica à difusão de vapor com o $\psi_{p}$ em plantas de feijoeiro, KANEMASU e TANNER (1969a) e 
JENSEN (1981) nao atingiram resultados satisfatōrios, explicando os autores que isto era devido ao fato de que o valor de $\psi_{p}$, determinado algebricamente, representa um valor médio para todas as cēlulas da amostra, e que somente os valores de $\psi_{p}$ das células guardas ou subsidiārias poderiam estar relacionados com a resistência estomática à difusão de vapor. Ainda com relação a isto deve-se levar em consideração a variabilidade espacial. No mesmo trabalho KANEMASU e TANNER (1969) apresentaram valores de resistēncia estomātica à difusão de vapor, com variações de $2,5 \mathrm{seg} \cdot \mathrm{cm}^{-2}$ à $20,0 \mathrm{seg} \cdot \mathrm{cm}^{-1}$ em função da localização da folha em relação aos pontos cardeais, enquanto que os valores de $\psi_{t}$ da folha tiveram variações de no máximo $0,3 \mathrm{MPa}$, sendo que esta diferença não foi constante e pode ser atē diminuída por uma menor variabilidade espacial dentro de um mesmo ponto cardeal.

Segundo DENMEAD e MILLAR (1976) a interpretação dos resultados de muitos experimentos não é fácil, devido a que a variação do potencial de āgua na planta ou a taxa transpiratória somente são determinadas em partes da planta. E segundo os autores è evidente que o potencial total da água da folha em um local particular de planta depende da distribuição da densidade do fluxo transpiratório na própria planta e do gradiente do prōprio $\psi_{t}$, sendo que variações neste ūitimo parâmetro em um determinado local pode não ser proporcional às variações da densidade de fluxo transpiratōrio desse mesmo local.

A falta de obtenção de resultados bem definidos quanto a influência dos parāmetros do meio e da prōpria planta no comportamento estomático e densidade de fluxo transpiratōrio com relação aos nīveis de 
potencial da āgua na planta è perfeitamente aceitável, pois a maioria dos trabalhos comentados anteriormente condicionaram as culturas ou plantas individuais a condições extremas onde a influēncia de um determinado parâmetro é predominante por atuar no limite ou fora da faixa daquela considerada normal para o desenvolvimento da cultura. Por outro lado, o sistema de amostragem para a obtenção de uma certa resposta da planta muitas vezes não conduz a valores médios representativos do fenômeno observado, não traduzindo o comportamento da planta como um todo em relação às condições vigentes. Outro fato que leva a umà interpretação inadequada dos resultados obtidos é a suposição de que somente um fator atua independentemente dos demais e que sua atuação serā sempre padrão dentro de condições ambientais e repetitivas em cada medida. Sabe-se no entan to que isto não ocorre e tal comprovação pode ser verificada no trabaTho de DENMEAD e MILLAR (1976) com a cultura de trigo onde afirmam que: a) a condutância difusiva dependeria primariamente da irradiāncia, quan do os potenciais de āgua estivessem acima dos seus valores críticos; b) quando um estresse hídrico moderado fosse induzido por alta demanda evaporativa, a condutância difusiva decresceria e limitaria a transpiração, numa extensão suficiente para evitar a diminuição do potencial da ãgua e valores abaixo dos níveis críticos; c) com estresses severos de āgua o controle estomático seria muito acentuado, com fechamento dos estômatos inicialmente nas folhas inferiores; os autores afirmam ainda que as previsões dentro da exploração agrícola requerem anālises mais detalhadas de todas as partes da cobertura vegetal. 
Os valores mais negativos do potencial total da ãgua na folha $\left(\psi_{t}\right)$ para a terceira época de plantio em relação à segunda, na variedade Aroana 80; pàrece ser proveniente de uma menor absorção de āgua pelas raj̃zes em função da diferente distribuição do sistema radicular, pois os valores de potenciais da água no solo mostraram que a terceira época levou um dia a mais que a segunda época para atingir o valor limite de mensuração do potencial matricial $\left(\psi_{m}\right)$ pelo tensiōmetro a $15 \mathrm{~cm}$ de profundidade. Também a este respeito deve-se considerar que a resistêncla estomática à difusão de vapor apresentou seus maiores valores na terceira época de plantio, e com relação à densidade de fluxo transpiratörio, estes valores são menores para esta mesma época. Por outro lado, a densidade de fluxo transpiratōrio apresentada é referente a unidade de superfície de folha, sendo que na ēpoca de medida do referido parâmetro, os valores de peso seco total e de indice de área foliar (IÁF) eran bem menores para a terceira época, o que talvez teriha provocado uma menor retirada de água do solo em relaçäo às plantas da seguncía época de plantio, que estavam bem mais desenvolvidas naquele perĩodo. A diferença de resistēncia estomática à difusão de vapor entre as épocas, por sua vez, pode ser função das condições dos estädios fenotögicos em que se en contravam, como mostraram PEET et alii (1977) ao observarem que os valores de resistência estomātica à difusão de vapor diferiram significativamente entre os estádios das plantas de feijoeiro, sendo que os valores deste parâmetro durante a formação de vagens foi $71 \%$ e $5 \%$ menores que durante o florescimento e o final de formação de vagens, respectivamente. 
A diferença entre as duas épocas também foi notada com relação ao potencial osmōtico e potencial matricial, sendo os valores dos mesmos na terceira época, em média, menores que os da segunda época, porēm esta diferença não foi suficientemente elevada para manter uma igualdade entre elas de valores de potencial de pressão $\left(\psi_{p}\right)$ sendo que valores de $\psi_{p}$ foram menores para a terceira época, que pode ser a causa da diferenciação entre elas de acúmulo de matéria seca, tanto em termos absolutos como em termos relativos. Ou seja, comparando a diferença de acúmulo de matéria seca entre o tratamento onde foi suspensa a irrigação e o tratamento irrigado, nota-se que foi maior na terceira do que na segunda época; e em termos absolutos pode-se verificar que no tratamento que sofreu o maior estresse hĩdrico o acūmulo da matéria seca foi maior para a segunda época em relação à terceira. Não se deve esquecer, porēm, o fato de que a segunda época teve uma maior recuperação no crescimento apōs o reumedecimento do solo, talvez em função do prōprio estádio de crescimento em que se encontrava e da prōpria diferença de $\psi_{\mathrm{p}}$ ocorrida no período de suspensão da irrigação.

As curvas de variação de $\psi_{t}$ (figuras 14 e 15) mostram que as maiores taxas de recuperação ocorreram entre 15:30 e 18:00 horas, coin cidindo com o período em que ocorreu o aumento dos valores de resistência estomáticà à difusão de vapor de água e decréscimo da densidade do . fluxo transpiratōrio, mostrando ter havido um efeito integrado entre a diminuição da intensidade do fluxo de radiação e diminuição do défice de saturação do vapor aliada a um acréscimo da resistência estomática à difusão de vapor. A elevação dos valores de $\psi_{t}$ próximos ao meio do dia, 
em alguns dias de medida dentro da variedade Aroana 80 , pode ter sido causada por uma variabilidade espacial decorrente do movimento parahelio trópico apresentada pelas folhas da cultura ou pela própria sistemática de amostragem. Por outro lado, pode se pensar em uma resposta da planta a algum outro parâmetro do meio ou da prōpria planta, apesar de que os. valores de resistência estomática à difusão de vapor neste horārio não se mostraram sistemáticos a esta variação de $\psi_{t}$, pois a elevação do mesmo somente esteve presente com tanta frequēncia neste horário.

A variabilidade bastante grande nos valores de $\psi_{\mathrm{p}}$ pode ser em parte explicada pelo acúmulo dos erros cometidos nas determinações dos outros termos da equação utilizada na sua estimativa. Da mesma maneira ACKERSON (1977), trabalhando com a cultura da soja, mostrou que os valores de potencial osmótico $\left(\psi_{0}\right)$ e potencial total $\left(\psi_{t}\right)$ não variaram correspondentemente e assim obteve valores anōmalos de $\psi_{\mathrm{p}}$ : No entanto, obteve o mesmo declinnio de $\psi_{p}$ nas primeiras horas da noite, como observado no presente estudo (figuras $13^{\circ}$ e 14 ), indicando que este comportamento talvez seja devido a algum processo metabōlico da planta que atua no equilíbrio hĩdrico das células.

Os valores de potenciais da āgua na planta não chegaram a ter uma influência drāstica no comportamento estomátịco mas provave1mente tiveram influência no processo de expansão das folhas. Pela tabela 3 nota-se que o valor médio de $\psi_{p}$ na maioria dos dias esteve acima de $+0,5 \mathrm{MPa}$, com valores médios para todos os dias medidos de +0,62 e $+0,53 \mathrm{MPa}$. para a segunda e terceira época respectivamente. Estes valores, 
pelos dados de bibliografia, não poderiam afetar grandemente os processos responsāveis pelo crescimento e desenvolvimento das plantas, porēm, ná anālise diāria podemos notar que houve valores de $\psi_{p}$ abaixo de 0,4 MPa. BOYER e MCPHERSON (1975) afirmam que baixos valores do potenciai de āgua na planta influenciam a produção de folhas atravēs de seus efeitos na iniciaçãc foliar e subsequentes processos de divisão celular. A elongação celular pode ser afetada por flutuações normais e rāpidas de $\psi_{t}$, enquanto que o processo fotossintético necessita de um maior nível de dēfice hídrico para ser afetado, sendo a translocação de assimilados menos sensivel ainda.

Segundo HSIAO et alii (1979) a primeira indicação da deficiência hĩdrica è a redução no tamanho da planta em relação àquelas com ampla disponibilidade de āgua no solo, porém a variabilidade dos valores nas determinações do potencial de āgua na planta somente torna pos sível a determinação do nívei de influência, mais tarde, quando o estres se causa uma resposta mais nitida. Comparando-se este processo com a abertura estomātica, assimilação de $\mathrm{CO}_{2}$ e transpiração, estes são processos bem menos sensíveis e a diminuição dos mesmos ocorre quanto o $\psi_{t}$ atinge de -1,2 a -1,6 MPa, dependendo da espécie e condições anteriores de crescimento. Este nível inicial corresponde grosseiramente ao início do murchamento visual e ē o ponto no qual o $\psi_{p}$ se aproxima de zero, se gundo Turner (1974) citado por aquele autor.

Em feijoeiro, MILLAR e GARDNER (1972) em um experimento de campo, mostraram que a produção de matēria seca pela cultura decresceu rapidamente quando a média diāria de $\psi_{t}$ atingiu valores menores que $-0,8 \mathrm{MPa}$. 
0'TOOLE et alii (1977), em estudo do efeito do estresse hĩdrico, na taxa fotossintētica das plantas de feijoeiro, determinou que a fotossintese e a transpiração aproximaram-se de zero quando $0 \psi_{t}$ atin gia valores de $-0 ; 9 \cdot \mathrm{a}-1,0 \mathrm{MPa}$.

Trabalhando com frequência de irrigação em cultura de fẹ joeiro, RESENDE et alii (1981) determinaram que, a potenciais de āgua na folha superiores a $-1,2 \mathrm{MPa}$, as resistēncias estomāticas à difusão de vapor de āgua e a taxa fotossintética não foram afetadas e que, no entan to, a ārea fotossintetizante, a matéria seca e a produção final de grãos foram reduzidas de acordo com a redução da evapotranspiração, a qual foi dependente da frequēncia da irrigação.

Como se pode notar pelos dados de literatura, o primeiro processo a ser afetado em relação à fotossīntese, perda de āgua, translocação e outros, durante uma evolução de um estresse hĩdrico ē o de expansão foliar e que mesmo curtos espaços de tempo ao longo do dia, nos quais a planta permaneça com o potencial da āgua com nîveis baixos, afeta a expansão e aparecimento de novos órgãos. № presente experimento, os potenciais da āgua na folha que ocorreram no perīodo de suspensão da irrigação, afetaram o crescimento da cultura, fato este com provado através dos resultados apresentados na figura 7: Apesar dos potenciais da āgua na folha atingirem valores inferiores àqueles considerados críticos à maioria dos processos fisiológicos apresentados na literatura, pela anālise dos valores de resistência estomática a difusão de vapor e de densidade de fluxo transpiratōrio pode-se afirmar que o processo fotossintético e a perda de āgua pelas follhas não foram 
visivelmente afetados pelo fechamento estomático. 0 principal efeito responsāvel pela menor produção de matéria seca por unidade de superfĩcie de terreno, foi o de expansão e aparecimento de novos órgãos, processo este que diminuiu, provavelmente, não o processo da fotossintese mas sim a taxa fotossintētica global, atravēs da redução da superfície foliar fotossinteticamente ativa. Pode-se afirmar com segurança que estes processos (expansão e aparecimento de novos ógãos) foram afetados por potenciais da āgua na folha contidos dentro das faixas atingidas pela cultura neste experiment•, ou seja, de 0 a aproximadamente $-1,4 \mathrm{MPa}$ para o potencial total da água na folha e de valores acima de t0,2 $\mathrm{MPa}$ para o potencial de pressão, e que estas mesmas faixas não contiveram os potenciais considerados criticos para os demais processos anteriormente discutidos.

No presente experimento a dificuldade de se obter um valor de $\psi_{t}$ limite ou crītico è perfeitamente explicāvel, jāque o mesmo foi determinado em apenas um tipo de folha na planta (superior totalmente expandida) sendo que os valores de $\psi_{t}$ nas folhas em desenvolvimento e naquelas mais velhas situadas inferiormente não foram determinados, is to porque tal procedimento acarretaria uma falta de padronização das medidas, o que ocasionaria uma variabilidade muito grande dos resultados, dificultando a anälise posterior. A folha tomada para a amostragem do $\psi_{t}$ talvez seja justamente aquela que menos responda à condição de estres se, não respondendo de imediato às condições flutuantes e extremas do meio. No caso do processo de expansão de folhas a determinação do $\psi_{t}$ crîtico para o processo sō pode ser feita atravēs de medidas individuais 
em cada folha; isto, no entanto, requereria uma amostragem ampla e detalha da em todo o dossel vegetativo e em vārios estāgios de desenvolvimento da folha em questão. Por outro lado, tal procedimento acarretaria um acompanhamento de $\psi_{t}$ e do processo de expansão das folhas por vārios dias, o que impediria a utilização de processos destrutivos na determinação do $\psi_{t}$ tal como é o caso do processo higrométrico utilizado neste estudo. Deve-se tambēm levar em consideração que, para um mesmo valor crītico de $\psi_{t}$ ocorrendo em diferentes estādios da cultura, sua influência nos processos metabōlicos pode ser diferente, pois segundo FRASER e BIDWELL (1974) trabalhando com plantas de feijoeiro, quando novos pontos de consumo de assimilação ("sink") se desenvolvem, tal como folhas ou flores, a taxa de troca gasosa nas folhas existentes è alterada, isto porque a taxa de translocação de assimilados aumenta, sendo que estes movem-se das folhas mais velhas para aquelas mais novas e este processo global ē bem mais constante durante a fase reprodutiva. Desta maneira, pensar em apenas um valor crítico de $\psi_{t}$ exclusivamente para um único processo, ē ignorar o dinamismo interno dos processos fisiológicos de cada planta em cada variedade.

Assim, a não caracterização de um valor crítico do potencial da ăgua na folha para o processo de expansão das folhas ou para 0 acúmulo de matéria seca não deve ser considerada como um resultado anormal ou inesperado, sendo ainda mais justificado devido ao fato de que as determinações foram feitas em plantas crescendo em condições de campo, nas quais os mecanismos que interagem entre si são inūmeros e o isolamen to de qualquer um deles è dificultado. 
Para relacionar o potencial da ăgua na folha e o potencial da ăgua no solo foram utilizados diversos valores de potencial de āgua na planta e de potencial da āgua no solo, obtidos em vārios horārios e nas diversas camadas do solo, não se obtendo uma relação satisfatōria. ACKERSON (1977) relata que encontrou dificuldade em relacionar os dois parâmetros quando trabalhou com sorgo, em função de não ter determinado a distribuição do sistema radicular, o que não permitiu caracterizar a camada de solo onde ocorreu a maior extração de āgua e como a distribuição das raĩzes foi afetada pelo estresse hĩdrico.

ZISKA e HALL (1983) ao trabalharem com Vicia faba no campo, concluiram que valores : determinados ao nascer do sol não se revelaram uma boa medida para detectar diferenças entre tratamentos de irrigação, pois as diferenças de $\psi_{t}$ obtidas foram sempre pequenas e variadas, havendo necessidade de muitas determinações para que as mesmas fossem aceitas com segurança.

No entanto, para a anālise destas relações deve-se levar em consideração a quantidade de āgua no solo, pois segundo HSIAO et alii (1979), os melhores horärios para se estudar as respostas das plantas ao estresse hidrīco são no início da manhã, quando a planta tem toda a noite para entrar em equilíbrio hỉdrico com o solo, indicando assim indiretamente o nīvel de umidade deste ūltimo. Em solos secos, com potenciais em torno de -1,0 $\mathrm{MPa}$ ou menos, nos $50 \mathrm{~cm}$ superiores do perfil e para uma cultura que esteja com o seu sistema radicular nesta faixa de profundidade, a mesma pode apresentar valores de $\psi_{t}$ pela manhã de atē $-1,3 \mathrm{MPa}$. Ao contrārio, uma cultura com 10\% de seu sistema radicular 
abaixo desta camada, em contato com o subsolo úmido, pode apresentar va lores de $\psi_{t}$ em torno de $-0,2$ a $-0,3 \mathrm{MPa}$.

Quanto ao fato em questão, para a maioria dos solos onde as plantas agrĩcolas são cultivadas, as caracterîsticas quîmicas e físicas não são homogēneas dentro de cada camada estudada e nem tampouco ao longo do perfil; assim, a adoção de um único potencial matricial da āgua do solo para todo um perfil estudado ē uma aproximação ampla e pode ma carar a interação entre a diferente distribuição da densidade de raĩzes no perfil e a heterogeneidade do perfil do solo quanto às suas diversas propriedades. Por outro lado os valores determinados do potencial da āgua no solo $\left(\psi_{S}\right)$ devem sofrer uma anāilise crītica antes de serem utilizados para qualquer relação no Sistema Solo-Planta-Atmosfera (SSPA), pois muitos desses são determinados instantaneamente com apenas um valor diario e muitas vezes sendo tomados em horārios distintos, o que, como nota-se pela figura 27 , pode originar valores variados de $\psi_{s}$ somente devido a determinações em horārios diferentes, mascarando possīveis relações. Os valores de $\psi_{S}$, em cada camada, devem ser analisados em fun ção da espessura da camada que representam e de como foram determinados. Quando o $\psi_{S}$ é determinado através do método tensiométrico deve-se levar em consideração: o número de repetições feitas em cada camada; que os valores obtidos atravēs dos mesmos são provenientes da interação da cāpsula com uma camada do perfil do solo com dimensões delimitadas pelas prōprias dimensões da cápsula porosa; a distribuição decrescente da quantidade de raízes ao longo do perfil, de acordo com a cultura em ques tão, o número de valores de $\psi_{\mathrm{S}}$ obtidos ao longo do perfii visando representar cada camada do mesmo. Quando os valores de $\psi_{\mathrm{S}}$ são determinados 
atravēs do método gravimétrico, deve-se considerar que a umidade do solo é obtida para toda uma camada do perfil, sendo que a curva caracterīstica na maioria das vezes é proveniente de pontos médios desta mesma camada e de poucas repetições para que possam representar a re]áção com acuracidade entre a umidade $(\theta)$ e o potencial matricial da āgua no solo $\left(\psi_{m}\right)$ para āreas de relativa extensão. Para experimentos em casas de vegetação $0 \psi_{\mathrm{S}}$ é determinado, na maioria das vezes, atravēs da pesagem dos vasos e das curvas caracterīsticas mēdias do solo, o que faz com que,dependendo do estádio de desenvolvimento da cultura e das dimensões das mesmas, a avaliação de alguma relação obtida possa diferir da. real ou somente ser vālida para experimentos nessas condições. No presente experimento,apesar da determinação das curvas caracterīsticas de umidade do solo atravēs de nove repetições dentro de uma mesma profundidade, representando com um bom grau de acuracidade a relação $\psi_{m} \times \theta$, deve-se con siderar que o tensiometro instalado mais superficialmente estava a $15 \mathrm{~cm}$ da superfície e que nesta camada de $0-15 \mathrm{~cm}$ está localizada a maior quantidade de raízes para esta cultura e que talvez, para um melhor detalhamento do estudo, dever-se-ia instalar um tensiōmetro a uma profundidade menor.

Quando foram comparadas as respostas das duas variedades quanto aos parâmetros medidos, notou-se que tiveram um comportamento di- . ferencial, apesar dos tratamentos de nīveis de água no solo serem semeThantes. Isto foi devido a comportamentos diferentes no que se refere a desenvolvimento, cobertura do solo, características morfológicas, concen trações de solutos, comportamento de fotonastismo e perda de folhas. 
Pela figura 7 nota-se que as duas variedades Aroana 80 e Aetē 3 tiveram comportamento diferente em termos de acūmulo de matéria se ca tanto ao longo do ciclo como tambëm durante o periodo de interrupção da irrigação, sendo que a Aroana 80 apresentou uma maior redução na matēria seca total que a variedade Aetē 3 , tanto em termos absolutos, como em termos relativos quando comparados com o tratamento sem suspensão da irrigação. Isto pode ser explicado por värios mecanismos. A variedade Aetē 3 apresentou um comportamento paraheliotrópico ben mais acentuado que a Aroana 80 e utilizou este mecanismo antecipadamente, tanto no trans correr do perĩodo de interrupção da irrigação como dentro de cada dia.Es te comportamento paraheliotrópico também foi notado em feijoeiro por KANEMASU e TANNER (1969) e DUBTEZ (1969). Segundo TURNER e BEGG (1981) ele è um mecanismo alternativo para as plantas adaptarem-se ao estresse hĩdrico sem afetar irreversivelmente a ärea foliar. A variação do ângu10 de exposição da folha aos raic:s solares reduz efetivamente esta incidēncia e leva as folhas a dissiparem menos calor latente. Ainda segundo os autores, este é um mecanismo importante de defesa, jā que opera somente durante perĩodos de estresse hĩdrico. Atravēs deste mecanismo as folhas evitam a incidéncia direta dos raios solares, diminuindo a pos sibilidade de um maior acréscimo de sua temperatura decorrente de uma maior transformação energia solar em calor sensīvel, devido a uma diminuição da densidade de fluxo transpiratório.

observou-se visualmente que as variedades apresentaram, para defesa contra o estresse hîdrico, uma redução da expansão foliar, e na variedade Aroana 80 apresentou-se o mecanismo de senescência das folhas 
inferiores, sendo talvez o mecanismo responsāvel pela maior diferença relativa entre as variedades quando se compara a taxa de acūmulo de matéria seca total entre os tratamentos com e sem suspensão da irrigação. Isto talvez esteja relacionado com a soma do potencial osmótico e matricial $\left(\psi_{0+m}\right)$, sendo que os valores na variedade Aeté 3 tiveram um acréscimo muito grande em comparação com os valores determinados no início do período de secamento, o qual pode advir de uma modificação do con teūdo de metabōlitos das cēlulas atravēs de processos de transformação ocasionados pelo estresse hîdrico. STEWART et alii (1966), ao trabalharem com plantas de feijoeiro, verificaram que o murchamento das folhas ocasionava um aumento no teor de açūcar e uma queda no teor de amido, nestas mesmas folhas. Estudos mais especificos nesse sentido podem ser sugeridos.

A variedade Aetē 3 apresentou, em termos médios, resistências estomāticas à difusão de vapor d'āgua (Rd) ligeiramente superiores à da variedade Aroana 80. No entanto, a densidade de fluxo transpiratōrio, na variedade Aeté 3 , na face superior foram em média superiores à da Aroana 80 na mesma face, e na face inferior estes valores foram superiores para a Aroana 80. Diferenças nas resistēncias estomáticas à difusão de vapor em variedades de feijoeiro foram observados por PEET et alii (1977) e por KUENEMAN et alii (1975). As diferenças entre as variedades quanto a variação da relação transpiração-resistēncia estomātica à difusão de vapor em ambas as superfícies das folhas, pode ser pro veniente, em hipōtese, de uma diferença no sistema hidrāulico de condução, ou na disposição diferencial das cēlulas do mesōfilo foliar ou ainda 
do nūmero e tamanho dos estōmatos nas variedades.

Com relação ao consumo de āgua nota-se pelas figuras 4,5 e 6, que a variedade Aetē 3 provocou um menor esgotamento do solo. Um dos motivos dessa constatação pode ter sido os maiores valores de $R_{d} e$, em consequência, por uma menor densidade de fluxo transpiratōrio em relação à Aroana 30.

Pode-se dizer que os tratamentos de nîveis de āgua no so10 aos quais foram submetidas as duas variedades não foram suficientemente drāsticos para acentuar as diferenças de respostas entre épocas de plantio, para alguns parāmetros, sendo que as diferenças entre variedades tiveram uma contribuição do prōprio comportamento diferencial das mesmas quando em condiçōes de ampla disponibilidade hîdrica. Provavelmente um grau de secamento do solo mais drástico poderia levar a uma maior diferenciação nas respostas.

Muitos autores afirmam que, para a maioria dás espécies, aquela que apresenta uma maior tolerância ao frio apresenta também uma maior tolerāncia à seca, LEVITT (1972). Na variedade Aeté $3{ }^{\prime}$ observouse que, durante um perĩodo de baixas condições energéticas do ambiente, a mesma não mostrou sintomas visiveis de resposta a esta condição, sendo que a variedade Aroana 80 apresentou-se com suas folhas inferiores amare lecidas devido a um estado precoce de senescenncia provocado pelas condições citadas. Isso indica que aparentemente a variedade Aetē 3 tem um mecanismo preferível de defesa contra o défice hîdrico quando comparado à Aroana 80 dentro das condições que se apresentaram, porque a perda de folhas è mais prejudicial, em termos de recuperação posterior ao défice 
hîdrico, do que a paralização da expansão das folhas. A literatura mostra que a redução da ārea foliar, por si sō e independente dos outros efeitos causados pelo défice hîdrico sobre o desenvolvimento vegetal (aborto de flores, mā formação de vagens, aceleração da senescência, etc.) causa uma redução na produção final de grãos, de acordo com o estádio de desenvolvimento da cultura, grau de desfolhamento e densidade de plan tio, fato este comprovado por CHAGAS et alii (1979), CECILIA et alii (1980) e LINK et alii (1980), trabalhando com feijoeiro.

A produção final de grãos não foi comparada entre os diversos tratamentos, porque apōs o período de medida dos parāmetros hídricos no solo e na planta, ocorreram valores de F.A.D. atē de 100\%, inclusive com dias nos quais os valores do potencial hidráulico da água no solo foram positivos. Este fato foi causado pela alta densidade global da camada de solo na profundidade de $30-45 \mathrm{~cm}$ e pela baixa condutividade hidrāulica desta mesma camadá, que causou um acúmulo da água precipitada nas camadas superficiais, diminuindo grandemente a aeração do solo na re gião de maior concentração das raîzes. Em consequēncia disto, a verificação de provāvel diferença de produção entre os tratamentos da umidade do solo foi prejudicada pela queda de produção também nas parcelas on de a irrigação não foi suprimida, por influência direta da mā aeração do solo, fato comprovado por DASBERG e BARKER (1970), LEGARDA e FORSYTHE (1978) e DA SILVA (1982) e pela proliferação de fungos do solo que determinou uma queda da densidade populacional, dificultando a avaliação da produção. 
Os dados da figura 23 mostraram uma diferença não muito acentuada de F.A.D. entre os tratamentos onde se suprimiu a irrigação e aqueles onde a irrigação foi mantida. No entanto, deve-se levar em consideração a profundidade do perfil considerada, jā que no tratamento irrigado a maior F.A.D. estava localizada nas camadas onde se localizavam a maior parte dạs raízes. Pode-se considerar que o nível da F.A.D. para o tratamento onde não foi suspensa a irrigação não foi limitante à perda de āgua pełas culturas, pois segundo DOORENBOS e KASSAM (1979), para uma evapotranspiração diāria mēdia de 3, 4, 5, 6 e 7mm, o feijoeiro pode extrair 0,$70 ; 0,60 ; 0,50 ; 0,45$ e 0,43 da F.A.D., sem que a evapotranspiração mäxima seja afetada; e para o experimento os valores minimos da F.A.D. para o tratamento Aroana 80 (I) foram de 0,$52 ; 0,57$ e 0,60 e a ETm para estes períodos fo i ${ }^{\circ}$ em torno de $5,0 \mathrm{~mm}$ permanecendo assim dentro da faixa,a qual provavelmente não traz prejuízos ao crescimento ' e desenvolvimento da cultura.

Por outro lado o grau de secamento foi tambēm atenuado atravēs de uma redistribuição noturna de āgua no solo, sendo a mesma verificada pela diferença do potencial matricial entre as 18:15 horas (mais baixo) e a das 7:15 horas do dia seguinte (mais elevado).

HAISE e KELLEY (1950) verificaram uma grande variação de leitura dos tensiōmetros no decorrer do período diurno e noturno, onde o valor mīnimo foi atingido prōximo às 8:00 horas e o valor máximo às 20:00 horas, sendo que a diferença entre estas leituras atingiu atē cerca de $400 \mathrm{~cm} \mathrm{H}_{2} \mathrm{O}$ ou $0,04 \mathrm{MPa}$ mesmo quando o nível de água no solo permaneceu constante, e estas diferenças ao longo do perĩodo tenderam a 
valores maiores nas camadas mais superficiais e nos menores níveis de umidade do solo. Afirmam que esta variação foi influenciada por gradien tes de temperatura entre solo, aparelho e atmosfera, mas que estas flutuações foram grandemente diminuídas e quase insignificantes para os ten siōmetros de material plāstico. Durante o presente estudo a variação das leituras dos tensiōmetros em decorrēncia das oscilações térmicas pode ser considerada insignificante; ou seja a influência de gradientes de temperaturas entre a parte aérea do aparelho e a atmosfera adjacente não teve efeito significativo, pois quando o solo esteve com alta umidade (verificada pela não variação nas leituras das camadas mais inferiores) não ocorreram variações da leitura de $\psi_{m}$. Quando a ãgua do solo estava sendo esgotada, a variação de leitura entre o final do período diurno (prōximo às 18:00 horas) e a leitura inicial do dia seguinte ocor reu nas camadas de $15,30,45,60$ e de atē $75 \mathrm{~cm}$, com aproximadaniente a mesma intensidade entre os tratameiitos; no entanto esta mesma variação não ocorreu na camada de $30 \mathrm{~cm}$ para a segunda e terceira época de plantio da variedade Aetē 3 e na segunda época da variedade Aroana 80, demonstrando que se tivesse tido efeito significativo de temperatura estas mes mas leituras tambēm deveriam apresentar uma certa variabilidade. 


\section{CONCLUSÕES}

A variedade Aroana 80 apresentou häbitos de crescimento e estādios reprodutivos mais definidos em relação a Aeté 3 , ou seja, a taxa de acúmu lo de matēria seca da Aroana 80 foi diminuĩda durante 0 estādio reprodutivo enquanto a Aetē 3 apresentou emissão da guia vegetatị vo por ocasião do florescimento e um período de florescimento não tão definido em relação a anterior.

A diminuição do potencial da āgua na folha e valores relativamente baixos nos tratamentos com suspensão da irrigação na variedade Aroana 80 durante o perĩodo de maior deficiência hỉdrica no solo, não cau sou variações bruscas na resistência à difusão de va por de água e densidade de fluxo transpiratōrio nas duas variedades. Entretanto, a variação do potencial de água na folha foi influenciada pelo défice de saturação de vapor de água e pelo fluxo de radiação solar global ao longo do dia.

Foi notada diferença entre a segunda e terceira épocas de plantio e, portanto, quanto ao estádio de crescimento, no que se refere a soma do potencial osmötico e do matricial $\left(\psi_{0+m}\right)$ medidos nos tratamentos 
com suspensã̃o da irrigação e durante o perīodo de maior deficiência hīdrica. 0s menores valores de parāmetro na terceira época em relação à segunda não foram suficientes para manterem os potenciais de pressão em igualdade para as duas épocas, o que pode ter sido devido a causas da di ferenciação entre elas quanto ao acúmulo de matéria seca.

Não foi satisfatória a tentativa de se relacionar a densidade de fluxos transpiratório, potencial da água na foltha e resistência estomática a difusão de vapor d'água para determinar um nīvel crî́tico de energia para a água na folha que afetasse os mesmos parāmetros.

os valores de potencial da água na folha ocorrente no periodo de suspensão de irrigação afetaram o crescimento da cultura. Os valores mínimos atingidos de potencial de āgua na folha, da ordem de $-1,4 \mathrm{MPa}$, embora possam ser considerados críticos à maioria dos processos fisiológicos para o feijoeiro, bem como os valores de potencial de pressão acima de +0,2 $\mathrm{MPa}$, devem ter afetado em maior grau os procesisos de expansão e aparecimento de novos órgãos do que o processo fotossintético.A fotossintese global, portanto pode ter sido afetada mais pela redução da superfície foliar fotossinteticamente ativa do que pela intensidade do processo fotossintético em si.

Observou-se visualmente que as variedades apresentaram 0 processo de parahēliotropismo como um mecanismo de proteção contra o estresse hĩdrico, sendo que este processo apresentou-se de maneira mais precoce no Aetē 3, tanto no período de secamento do solo, quanto durante o fotoperíodo indicando que tal mecanismo foi mais intenso nessa variedade, além disso, ocorreu uma redução da expansão foliar nas duas 
variedades, o que deve ter contribuĩdo para uma menor perda de āgua e constituindo-se consequentemente, num mecanismo adicional de proteção con tra o estresse hỉdrico, sendo que o Aroana 80 apresentou suplementarmente a diminuição da ārea foliar por senescência das folhas inferiores, sen do este ūltimo o mecanismo responsāvel pela maior redução relativa entre elas quanto ao acúmulo de matéria seca, na comparação entre os tratamentos com e sem suspensão da irrigação.

A redistribuição noturna contribuiu para que a água no solo não atingisse nĩveis suficientemente drāsticos para acentuar as res postas entre épocas de plantio e variedades com relação aos potenciais da āgua na folha e resistência estomática à difusão de vapor.

A variedade Aeté 3 apresentou, em termos médios, valores de resistência estomática à difusão de vapor da água ligeiramente superiorc: a da Aroana 80. A densidade de fluxo transpiratório na Aeté 3 foi em média superior a da Aroana 80 na face superior.

Para·a variedade Aroana 80 a evapotranspiração acumulada desde a emergência até a maturação fisiológica, nos tratamentos sem interrupção da irrigação, foi menor, maior e intermediāria para a primeira, segunda e terceira épocas de plantio, respectivamente. Nos tratamentos com suspensão da irrigação os valores da evapotranspiração acumulada foram menores em relação aos constantemente irrigados e os vaḷores para a variedade Aroana 80 foram sempre maiores aos da variedade Aetē 3 salvo na terceira época de plantio. Para os tratamentos com suspensão da irrigação, à medida que se avançava na época de plar,tio os valores de evapotranspiração acumulada diminuiram. 


\section{B IBL IOGRAF IA}

ACKERSON, R.C.; D.R.KRIEG; T.D.MILLER e R.E.ZARTMAN, 1977. Water relations of field grown cotton and sorghum: temporal and diurnal changes in leaf water, osmotic, and turgor potential. Crop Sci. Madison, USA, 17:76-80p.

ANDREWS, R.E. e E.T.NEWMAN, 1969. Resistance to water flow in soil and plant. New Phytol. Cambridge, England, 68:1051-8p.

BEGG, J.E. e N.C.TURNER, 1981. Crop Water Deficits. Advances in Agronomy. New York, 28:161-217p.

BINNIE, R.C. e P.E.CLIFFORD, 1981. Flower and pod prodution in Phascolus vulgaris. J.Agric.Sci. Cambridge, Inglaterra, 97:397-402p.

BLACK, T.A.; C.B.TANNER e W.R.GARDNER, 1970. Evapotranspiration from a snap bean crop. Agronomy Journal, Washington, DC., 62:66-69p.

BLACK, T.A.; W.R.GARDNER e C.B.TANNER, 1970. Water storage and drainage under a row crop on a sandy soil. Agronomy Journal, Washington, DC. $62: 48-51 p$.

BLACK, C.R. e G.R.SQUIRE, 1979. Effects of atmospheric saturation deficit on the stomatal condutance or pearl millet (Pennisetum typhoides S. e H.) and groundnut (Arachis hypogea L.). J.of Exp.Bot., Oxford 30:935-45p. 
BLIZZARD, W.E. E J.S.BOYER, 1980. Comparative resistence of the soil and the plant to water transport. Plant Physiol., New York, 66:809-14p.

BOYER, J.S., 1969. Free-energy transfer in plants. Science, Washington, DC., 163:1219-20p.

BOYER, J.S., 1971. Resistances to water transport in soybean, bean, and sunflower. Crop Science, Madison, USA, :403-7p.

BOYER, J.S. e H.G.MCPHERSON, 1975. Physiology of water deficits in cereal crops. Advances in Agronomy, New York, 27:1-23p.

BURCH, G.J., 1979. Soil an Plant Resistances to water absorption by plant root systems. Aust.J.Agric.Res., Melburne, Austrālia, 30:279-92p.

BURMAN, R.D. E D.W.BOHMONT, 1961. Evaluating the growth rate of great northern beans as influenced by soil moisture level under greenhouse conditions. Agronomy Journal, Washington., DC., 354-355p.

CAMARGO, A.P.; H.S.PINTO; M.J.PEDRO JUNIOR; R.R.ALFONSI E A.A. ORTOLANI, 1974. Clima do Estado de São Paulo. In: Zoneamento Agrícola do Estado de São Paulo. São Paulo. Secretaria da Agricultura, vol. 1.

CECILIA, F.C.S.; M.A.P.RAMALHO e M.B.GOMIDE, 1980. Efeito do desfolhamento sobre a produção do faijoeiro (Phaseolus vulgaris L.). Cienc. Prāt., Lavras, MG, 4(1):66p. 
CENTRO INTERNACIONAL DE AGRICULTURA TROPICAL, (s.d.). Guia de estudos. morfologia de la planta de frijol comum (Phaseolus vulgaris). Cali, Colōmbia, Sērie 04 SB-09.01, 50p.

CHAGAS; J.M.; C.VIEIRA; M.MAESTRI e A.A.CARDOS0, 1979. Resposta de duas variedades de feijão (Phaseolus vulagaris L.) ao desfolhamento artificial. Ciência e Cultura, Viçosa, MG, 31(6):683-87p.

COWAN, I.R., 1977. Stomatal behavior and environmet. Adv. Bot. Res. New York, 4:117-228p.

DARCY, H., 1856. Les fontaines publique de la Ville de Dijon. Paris, Victor Dalmont, 592p.

DASBERG, S. e J.W.BAKKER, 1970. Characterizing soil aeration under changing soil moisture conditions for bean growth. Agronomy Journal Washington, $62(6) .689-92 p$.

DA SILVA, E.L., 1982. Suscetibilidade do feijoeiro (Phaseolius vulgaris L.) Cv. goiano precoce a inundações temporārias do sistema radicular em diferentes fases do seu ciclo vegatativo. Piracicaba, Dissertação 73p:

DAVIES, W.J., 1977. Stomatal Responses to water stress and light in plants grown in controlled environments on in the field. crop science, Madison, USA, 17:735-40p. 
DEMATTE, B.I.; E.A.BULISANI; L.D'A. ALMEIDA e S.ALVES. Irrgiação do feijoeiro. Instituto Agronōmico, Campinas, SP. 37:23p.

DEMATTE, J.B.I.; J.D.I. DEMATTE; S.MYASAKA; L.D'A. ALMEIDA; T.IGUE e S. ALVES, (s.d.) Irrigação $x$ adubação mineral $x$ matēria orgância em cultura de feijoeiro. Instituto Agronōmico, Campinas, SP, 15:27p.

DENMEAD, 0:T. e R.H.SHAW, 1962. Availability of soil water to plants as affected by soil moisture content and meteorological conditions. Agron. J. Washington, 54:385-90p.

DENMEAD, 0.T. e B.D.MILLAR, 1976. Field studies of the condutance of wheat leaves and transpiration. Agron. J. Washington, 68:307-11p.

DOORENBOS, J. e W.0.PRUITT, 1975. Crop water requirements. Rome. FA0. Ire. and Dranage, $24: 179 p$.

DOORENBOS, J. e A.H. KASSAM, 1979. Yeld response to water. Rome. FAO. Irrigation and Dranage, Paper no 33:191p.

DUBTEZ, S., 1969. An unusual photonastism induced by drowght in Phaseolus vulgaris. Can. J. of. Bot.,0ttawa, Canadá, 47:1640-41p.

DUBETZ, S. e P.S.MAHALLE, 1969. Effect of soil water stress on bush beans (Phaseolus vulgaris L.) at three stages of growth. J.Am.Soc.Hort.Sci. St. Joseph, $94: 479 p$. 
EL NADI, A.H., 1969. Water relations of beans. I. Effects of water stress on growth and flowering. Expl.Agric. London, Inglaterra, 5:195-207p.

ENCARNAÇAO, C.R.F., 1980. Estudo da demanda de água do feijoeiro (Phaseolus vulgaris L.) var. Goiano Precoce. Piracicaba, ESALQ. 62p. Dissertação de mestrado.

E.U.A., 1975. Soil survey stolf soil taxonomy - A basic sistem of soil classification for making and interpreting soil surveys. Agriculture Handbook; nọ 436 U.S. Government Printing 0ffice. Washington, D.C.

FARQUHAR, G.D., 1978. Feedforward responses of stomata to humidity. Aust.J.Plant.Physiol., Melburne, Austrālia, 5:787-800p.

FEHR, W.R. e C.E.CAVINES, 1977. Stages of soybeans developmert. Anes, Iowa State University of Science and Technology. 11p. (Special Report, $80)$.

FISCHER, .V.J. e C.K.WEAVER, 1974. Flowring, pod set, e pode retention of Lima Bean in response to night temperatura humidity and soil moisture. J.Am.Soc.Hort.Sci. (Sol) 99(5).448-50p.

FISCUS, E.L., 1979. Relationships betwen Root system water transpor.t properties and plant size in phaseolus. Plant Physiol., New York, 64: $770-73 p$.

FRASER, D.E. e R.G.S.BIDWELL, 1974. Photosynthesis and photorespiration during the ontogeny of the bean plant. Can.J.Bot., C.S.I.R.0., Camberra, Austrālis, $52: 2561-70 p$. 
GARDNER, W.R., 1960. Dynamic aspects of water availability to plants. Soil Sci., New Brunnwich, 89:63-73p.

GARDNER, W.R. e R.H.NIEMAN, 1964. Lower limit of water availability to plants. Science, Washington, DC. 43:1460-62p.

GLOVER, J., 1959. The apparent behavior of maize and sorghun stomato during and after drought. J.Agric.Sci. Cambridge, Inglaterra. 53: 412-6p.

GODOY, O.P.; J.T.M.ABRA.HAO; C.GODOY JUNIOR; R.GODOY E A.PETTA. 1966. A irrigação do feijoeiro (Phaseolus vulgaris L.). Rev. Agric. Piracica ba, SP, 41(4):145-53p.

HAISE, H.R. e 0.J.KELLEY, 1950. Causes of diurnal fluctuations of tonsiometers. Soil Science, New Brunswich, 4:301-13p.

HANSEN, G.K., 1974a. Resistance to water transport in soil and young wheat plants. Acta Agric. Scand., Stockholm, 24:37-48p.

HANSEN, G.K., 1974b. Resistance to water flow in soil and plants, plant water status, stomatal resistance and transpiration of italian ryegrass, as influenced by transpiration demand and soil water depletion. Acta Agric. Second, (s.1.) 24:37-48p.

HILLEL, D., 1970. Solo e āgua, fenômenos e princépios fésicos. Porto Alegre, RS, $\rceil^{a}$ edição. Ed.EMMA $231 p$. 
HIRON, R.W.P. e S.T.C.WRIGHT, 1973. The Role of endogenous abscisic acid in the response of plants to stress. Journal of Experimental Botany. 0xford, 24(81):769-81.

HOFFMAN, G.J.; J.A.JOBES; Z.HANSCOM E E.V.MAAS, 1978. Timing of environmental stress affects growth, water relations and sàlt tolerance of Pinto Bean. Transactions of the ASAE, Mich., USA, 71318.

HOFSTRA, G. è J.D.HESKETH, 1969. The effect of temperatura on stomatal aperture in different species. Can. Journal of Botany, C.S.I.R.O., Camberra, Austrālia, 47:1307-1310.

HSIAO, T.C.; J.C.0'TOOLE e V.S.TOMAR, 1979. Water stress as a constraint to crop production in the tropics. Apresentado na Conferência "Priorities for allevating soil-related constraints to food production in the Tropics". held at IRRI, Los Baños, Philippi nes, 4-8p.

INFORZATO, R. e S.MIYASAKA, 1963. Sistema radicular do feijoeiro em dois tipos de solo do Estado de São Paulo. Bragantia, Campinas, . São Paulo, 38(22):477-81p.

INSTITUTO AGRONÔMICO, 1982. Realizações do IAC; Novos cultivares. 0 Agronômico. Campinas, SP, 34:26p. 
JANES, B.E., 1948. The effect of varying amounts of irrigation on the composition of two varieties of snap beans. Proc. Amer. Soc. Hort. Sci. New York, 51:457-62p.

JENSEN, R.C., 1981. Influence of water and salt stress on water relationships and carbon dioxide exange of top and roots in beans. New Phytol. Cambridge, England, 87:285-295p.

KANEMASU, E.T. e C.B.TANNER, 1969a. Stomatal difusion resistance of snap beans, I. Influence of leaf water potential. Plant Physiol. New York, 44:1547-52p.

KANEMASU, E.T. e C.B.TANNER, 1969b. Stomatal difusion resistence on snap beans, II. Effect of 1ight. Plant Physiol. New York, 44:1542$46 p$.

KATTAN, A.A. e J.W.FLEMIN, 1956. Effect of irrigation at specific stages of development on yield, quality, growth and composition of beans. Proc.Am.Soc.Hort.Sci. New York, 68:329-42p.

KUENEMAN, E.A.; D.H.WALLACE e P.M.LUDFORD, $1979 . \quad$ Photosynthetic measurement of field grown dry beans and their relations to selection for yield. J.Am.Soc.Hort.Sci., St. Joseph, 104(4):480-82p.

LANGE, 0.L.; R.LOSCH; E.D.SCHULZE e L.KAPPEN, 19?1. Responses of stomata to changes in humidity. Planta, Berlin, Alemanha, 100:76-86p. 
LAWN, R.J., 1982a: Response of four grain legumes to water stress in South-eastern Queens?and. I. Physiological response mecanisms. Aust. J. Agric. Res. Melbourne, Austrāilia, 33:481-96p.

LAWN, R.J., 1982b. Response of four grain legumes to water stress in South-ëastern Queensland. II. Plant growth and soil water extraction patterns. Aust. J. Agric. Res. Melbourne, Austrālia, 33:497-509p.

LAWN, R.J., 1982C. Response of four grain legumes to water stress in South-eastern Queesland. III. Dry matter production, yield and water use efficiency. Aust.J.Agric.Res. Melburne, Austrālia, 33: 511-521p.

LEGARDA, L. e W.FORSYTHE, 1978. Soil water and aeration and Red bean production. II. Effect of soil aeration. Turrialba, Costa Rica, $28(3): 175-7 p$.

LEVIT, J., 1966. Resistance to water transport in plants-A misconception. Nature, London, Inglaterra, 5061:527p.

LEVITT, J., 1972. Responses of plants to environmental stress. Academic Press, 697p.

LIBARDI, P.L.; K.REICHARDT; D.R.NIELSEN e J.W.BIGGAR, 1980. Simple field methods for estimating soil hydraulic condutivity. S.S.S.P.A. Detroit, Michigan, 44(1):3-7p. 
LINK, D.; E.C.COSTA e J.A.V.PANICHI, 1980. Efeito do desfolhamento. artificial no rendimento de quatro variedades de feijoeiro (Phaseolus vungaris L.). Rev. Centro Ciências Rurais, Santa Maria, RS. $10(4): 329-33 p$.

LUCHIARI, J.A., 1978. Determinação do coeficiente de cultura (Kc) para feijão (Phaséolus vulgaris L.) pelo método do balanço hĩárico. Piracicaba, Dissertação, 59p.

MACKLON, A.E.S. e P.E. WEATHERLEY, 1965. Controlled environment studies of the nature and origins of water deficits in plants. New Phytol., Cambridge, England, 64:414-27p.

MAGALHÆ̃ES, A.A. e A.A.MILLAR, 1978. Efeito do déficit de āgua no perĩodo reprodutivo sobre a produção do feijão. Pesq.Agropec.Bras. Brasilia, DF, 13(2):55-60p.

MAURER, A.R.; D.P.ORMOROD e N.J.SCOTT, 1969. Effect of five soil water regimes on growth and composition of snap beans. Con.J.Plant Sci. Ottawa, Canada, 49:271-78p.

MILLAR, A.A. e W.R.GARDNER, 1972. Effect. of the soil and plant water potentials on the dry matter production of snap beans. Agron. J. Washington, 64:559-62p. 
MOLDAU, Kh.A. e A.Y.SYBER, 1974. Effect of air humidity an the conductivity of stomates and mesophyll an bean leaves at two values of soil moisture. $\quad: 663-8 p$

MUIRHEAD, W.A. e R.J.G.WHITE, 1981. The influence of soil water potential an the flowering pattern, pod set and Yield snap beans (Phaseolus vulgaris L.) Irrigation science. Jerusalen, 3:45-56p.

OMETTO, J.C., 1981. Bioclimatologia Vegetal. São Paulo. ed. Agronōmica Ceres. 440p.

O'TOOLE, J.C.; J.L.OZBUN e D.H.WALLACE, 1977. Photosynthetic response to water stress in Phasealus vulgaris. Physiol. Plant. Oxford, England, 40:111-14p.

PEET, M.M.; A.BRAVO; D.H.WALLACE e J.L.OZBUN, 1977. Photosynthesis, stomatal resistance, and enzyme activities in relation to yield of field-grown dry bean varieties. Crop Science, Madison, USA, 17:287$93 p$.

RANZANI, G.; 0.FREIRE e T.KINJ0, 1966. Carta de solos do município de Piracicaba, Centro de Estudos de Solos. ESALQ-USP, Piracicaba, SP.

REICHARDT, K.; P.L.LIBARDI e J.M.SANTOS, 1974. An analysis of soil water movement in the field. II. Water balance in a snap bean crop. In: Centro de Energia Nuclear na Agricultura. Piracicaba,SP. B.C. $22: 19 p$. 
REICHARDT, K. 1975. Processos de transferência no sistema Solo-Planta-Atmosfera. 3åa edição. Centro de Energia Nuclear na AgriculturaUSP-CNEN e Fundação Cargi11. 288p.

REICOSKY, D.C. e J.T.RITCHIE, 1976. Relativa importance of soil resistance and plant resistance in root water absorption. Soil sci. Soc.Am.J., Detroit, Michigan, 40:293-7p.

RESENDE, M.; D.W.HENDERSON e E.FERERES, 1981. Frequência de irrigação, desenvolvimento e produção do feijão Kidney. Pesq.Agropec. Bras., Brasilia, 16(3):363-70p.

RITCHIE, J.T., 1974. Atmospheric and soil water influences an the plant water balance. Agric. Meteorology, Amsterdam, 14:183-98p.

RITCHIE, J.T.; 1981. Water dynamics in the soil-plant-atmosphere system. Plant and Soil. London, England, 58:81-96p.

ROWSE, H.R. e D.GOODMAN, 1981. Axial resistance to water movement in broad bean (Vicia faba) roots. J.of Exp.Bot: Oxford, 32(128):591-98p.

SAMUI, R.P. e S.KAR, 1981. Soil and plant resistance effects on transpirational and leaf water responses by groundnut to soil water-potential. Aust.J.Soil.Res., Melburne, Australia, 19:51-60p.

SANCHEZ-DIAZ, M.F. e H.A.MOONEY, 1979. Resistance to water transfer in desert shrubs native to death valley, California. Physiol. Plant. New York, 46:139-46p. 
SÃO PAULO. Secretaria da Agricultura e fbastecimento. Instituto de Economia Agrícola; 1983. Prognástico 83/84, 12:241p.

SCHULZE, E.D.; O.L.LANGE; U.BUSCHBOM, L. KAPPEN e M.EVENARI, 1972.Stoma tal responses to changes in humidity in plants growing in the desert. Planta, Berlim, Alemanha, 108:259-70p.

SHERIF, D.W. e R.SINCLAIR, 1973. Flutuations in leaf water balance, with a period of. 1 to 10 minutes. Planta, Berlim, Alemanha, 113: 215-28p.

SHERIFF, D.W., 1974. Transient changes in water uptake into shoots following a change in environment. J.of Exp. Botany. Oxford, 25(36): 575-579p.

SHERIF, D.W. e H.MEIDNER, 1974. Water phathways in leaves of Hedera relise L. and Tradescantia virginiana L. Jor. of Exp. Bot. 0xford, 25(89):1147-56p: .

SHOLANDER, D.F.; H.T.HAMMEL; E.D.BRADSTREET e E.A.HEMMINGSEN, 1965. Sap pressure in vascular plants. Science, Washington, DC. 148: $339-46 p$.

SILVEIRA, P.M. e L.F.STONE, 1979. Balanço de āgua na cultura do feijão em Latossolo Vermelho-Amarelo. Pesq.Agropec. Bras.Brasîlia, DF. $14(2): 111-15 p$. 
SILVEIRA, P.M.; T.A.P.CASTRO e L.S.STONE, 1980. Idade de floramento e vingamento de flores em duas cultivares de feijão. Pesq.Agropec. Bras. Brasilia, DF., 15(2):229-32p.

SILVEIRA, P.M.; C.M.GUIMARAEE; L.F.STONE e J.KLUTHCOUSHI, 1981. Avaliação de cultivares de feijão para resistência à seca baseada em dias de estresse de água no solo. Pesq.Agropec.Bras. Brasîlia, DF, $16(5): 693-99 p$.

SLAVIK, B., 1974. Methods of studing plant water relations. Nova York; Springer-Verlag Berlin Heildelberg, 449p.

STANSELL, J.R. e. D.A.SMITTLE, 1980. Effect of irrigation regimes an yield and water use of snap bean (Phaseolus vulgaris L.). J.Amer. Soc.Hort.Sci., St. Joseph, 105(6):869-73p.

STEWART, C.R.; C.J.MORRIS e J.F.THOMPSON, 1966. Changes in aninoacid content of excised leaves during incubation. II. Role of. sugar in the accumulation of proline in wilted leaves. Plant Physiology, New York, $41: 1585-90 p$.

TAERUM, R., 1973. Occurrence of inverted water potential gradients between soil and bean roots. Plant Physiology, New York, 28:471-75p.

TAYLOR, H.M. e B.KLEPPER, 1975. Water uptake by cotton root systems: and examination of assumption in the single root model. Soil science, New Brunswick, NJ, 120:57-67p. 
TURNER, N.C., 1974. Stomatal behavior and water status of maize, sorghum, and tobacco under, field conditions. Plant Physiol. New York, 53:360-65p.

TURNER, N.C. e J.E.BEGG, 1981. Plant-water relations and adaptation to stress. Plant and Soil, London, England, 58:97-131p.

TURNER, N.C., 1982. The role of shoot characteristics in drought resistance of crop plants. In: Droug Resistance in Crops with Emphasis on Rice. IRRI. Los Baños, Laguna, Phillipines, $411 \mathrm{p}$.

VEGA, J.D. e F.CANTU, 1982. Analisis de la relacion Clima-Agua de algunos cultivos como apoyo a la calendarizacion y cuantificacion del àgua de riego. Turrialba, Costa Rica, 32(2):155-159p.

VOLKENBURGH, van E. e R.E.CLELAND, 1981. Control of light-induced bean leaf expansion: Role of osmotic potential, wall yield stress, and hidraulic conductivity. Planta, Berlin, Alemanha, 153:572-7p.

WALKER, G.K. e J.L.HATFIELD, 1979. Test of the stress-degree-day concept using multiple planting dates of red kidney beans. Agronomy Journal, Washington, DC, 71:967-71p.

WILSON, J.M., 1976. The mechanism of chill - and drought - hardining of Phaseolus vulgaris leaves. New Phustol. Cambridge, England, 16: 257-70p. 
ZISKA, L.H. e A.E.HALL, 1983. Seed yields and water use of cowpeas (Vigna unguiculata (L.) Walp.) subjected to planned-water-deficit irrigation. Irrig:Sci., Jerusalem, 3:237-45p.

ZUR, B.; J.W.JONES; K.J.BOOTE e L.C.HAMMOND, 1982. Total resistence to water flow in field soybeans: II. Limiting soil moisture. Agron. J., Washington, 74:99-105p. 